\title{
Regulation of small-conductance, calcium- activated potassium channels (SK) in mouse brain in response to aging and stress
}

\author{
Dissertation \\ zur Erlangung des Doktorgrades \\ der Mathematisch-Naturwissenschaftlichen Fakultäten \\ der Georg August Universität zu Göttingen
}

\author{
vorgelegt von \\ Min-Jeong Kye \\ aus Anyang, Süd Korea
}

Göttingen 2004 
D7

Referent: Prof. Dr. Rüdiger Hardeland

Korreferent: Prof. Dr. Friedrich-Wilhelm Schürmann

Tag der Mündlichen Prüfung : 1, Juli, 2004 
For my grandparents 


\section{Contents}

Chapter 1: General Introduction

page

1. Hippocampus and learning and memory

\section{SK channels and afterhyperpolarization (AHP)}

2.1 Small-conductance calcium-activated potassium channels 6

2.2 Regulation of slow AHPs by neurotransmitters 7

2.3 Kinetics of sAHPs 8

$\begin{array}{ll}2.4 \text { Genes encoding SK channels } & 8\end{array}$

\section{HPA axis and learning}

3.1 HPA axis 9

3.2 HPA axis, stress and aging 9

\section{Regulation of gene transcription by steroid receptors}

4.1 Genomic action of steroids 11

$\begin{array}{ll}4.2 \text { Structure of steroid receptors } & 11\end{array}$

4.3 Mechanism of steroid hormone regulation of target genes 11

4.4 Role of steroid hormone receptors in target gene transcription 12

4.5 The role of steroid hormones in receptor function 12

4.6 Synergistic interaction of steroid response elements 13

\section{Nuclear Factor - kappaB}

5.1 Regulation of NF-kappaB 13

5.2 Function of NF-kappaB 15

5.3 Interaction of NF-kappaB and glucocorticoid receptors 16 


\section{Impact of aging on learning}

6.1 Anatomical and physiological changes in aged animals 17

6.2 Age-dependent changes in synaptic plasticity 18

$\begin{array}{ll}\text { 6.2.1 LTP } & 19\end{array}$

6.2.2 Age-related changes in LTP 19

$\begin{array}{ll}\text { 7. Aim of this study } & 20\end{array}$

$\begin{array}{ll}\text { 8. References } & 21\end{array}$

Chapter 2: Transcriptional regulation of the mouse gene for the calciumactivated potassium channel SK2 in PC12 cells

Chapter 3: Transcriptional regulation of the mouse gene for the calciumactivated potassium channel SK2 gene in mouse hippocampus generates age-related memory and LTP deficits

Chapter 5: Summary and conclusion

List of publication

Acknowledgement

Curriculum Vitae (Lebenslauf) 


\section{Chapter 1}

\section{General Introduction}

\section{Hippocampus and learning and memory}

Anatomically the hippocampus is composed of four regions, CA1, CA2 and CA3 pyramidal cell regions and the dentate gyrus and clearly plays a role in both navigation and memory processing (Sweatt, 2003). The hippocampal system is learning what the situation is, forming declarative or episodic memories about the events and their relationships in the context of the organism's ongoing experience (Eichenbaum, 1999). This assumption is based on experiments, which report that hippocampal principal neurons-'place cells'-exhibit location-specific firing (Winson et al., 1978). There is further evidence that hippocampal neurons are required for multi-modal sensory integration (Shapiro et al., 1997; Tanila et al., 1997). The hippocampus is also crucial for trace conditioning, a procedure where a period of no stimuli intervenes between the conditioned stimulus and the unconditioned stimulus (Mehta et al., 1997; Quirk et al., 2001). In support of this hypothesis, animals with hippocampal lesion have problems to associate two different episodes separated in time (Squire et al., 1991; Clark et al., 1998; Hueta et al., 2000).

\section{SK channels and afterhyperpolarization (AHP)}

\subsection{Small-conductance calcium-activated potassium channels}

Small conductance calcium-activated potassium channels play an important role in excitable cells. They are potassium selective, voltage independent and activated by intracellular calcium as seen during an action potential. As the action potential decays, the membrane potential repolarizes, and the internal calcium level rises, inducing an afterhyperpolarization (AHP). The initial faster phase is due to the activation of large- 
conductance voltage- and calcium-activated potassium channels (BK), while the slower phase is due to the activation of SK channels, which are gated by intracellular calcium ions (Bond et al., 1999).

As SK channels activate, they extrude potassium ions from the cell, moving the membrane potential to more negative potentials. SK channels generate a slow afterhyperpolarization (sAHP), with a time course that reflects the decay of intracellular calcium (Blatz and Magleby, 1986; Sah et al., 1996). The membrane hyperpolarization caused by SK channels inhibits further cell firing even in response to incoming depolarizing signals. This so-called spike-frequency adaptation or accommodation protects the cell against the deleterious effects of continuous tetanic activity and is essential for neurotransmission (Sah et al., 1996; Madison et al., 1984; Lancaster et al., 1986; Hille et al., 1992).

Two kinds of sAHPs are reported based on their time course and pharmacology. Apamin-sensitive sAHPs are observed in hippocampal interneurons (Zhang et al., 1995) and rat adrenal chromaffin cells (Park, 1994). Apamin-insensitive AHPs are documented in the hippocampal neurons, where apamin does not have any effect on sAHPs (Sah et al., 1996; Lancaster et al., 1986).

\subsection{Regulation of slow AHPs by neurotransmitters}

Many neurotransmitters modulate the currents underlying sAHPs (Nicoll et al., 1988), which in turn affects neuronal excitability (Gorelova et al., 1996). Noradrenaline, dopamine, serotonin, histamine, acetylcholine (via muscarinic receptors), glutamine (via metabotropic receptors), and some neuropeptides (i.e. VIP, CRF) suppress the apamininsensitive sAHP (Haug et al., 2000). As a consequence, neuronal excitability is enhanced, spike frequency adaptation is strongly decreased, and the number of action potentials evoked by a certain depolarizing stimulus is increased. In contrast, adenosine can decrease neuronal excitability by increasing the apamin-insensitive sAHP (Strom, 1990). Modulatory neurotransmitter systems can control the functional state of the brain by regulating the level of excitability in neurons. 


\subsection{Kinetics of sAHPs}

Apamin-sensitive sAHPs have faster kinetics than apamin-insensitive sAHPs. In some cells, such as in hippocampal interneurons, the apamin-sensitive sAHP is maximal following an action potential and decays with a half-time in the order of hundreds of milliseconds (Zhang et al., 1995). Apamin-insensitive sAHPs as seen in hippocampal pyramidal neurons, rise and decay over several seconds (Sah et al., 1996; Lancaster et al., 1986). A faster apamin-sensitive AHP is referred to the medium AHP (mAHP). Only the sAHP is modulated by neurotransmitter-induced second-messengers, whereas the mAHP is not known to be modulated by second-messenger cascades (Bond et al., 1999).

\subsection{Genes encoding SK channels}

Three genes encoding SK channels have been cloned from the mammalian brain (Kohler et al., 1996). Although the SK channel amino acid sequences are very different from other potassium channels, they show high degrees of homology among each other (Kohler et al., 1996). Recent studies have reported that calcium ions do not bind SK channels directly, but modulate gating of SK channels via binding to calmodulin (Maylie et al., 2004; Lee et al., 2003; Sailor et al., 2002; Schumacher et al., 2001). All three SK channels show similar calcium sensitivity. Elevated intracellular calcium concentrations increase the relative contribution of long open times and short closures of the channels, and changing membrane voltage alters none of the open or closed states (Maylie et al., 2004; Lee et al., 2003; Bond et al., 1999).

The cloned SK channels reflect the pharmacological variation of AHPs. SK1, which is known as apamin-insensitive, is expressed in regions that have apamininsensitive sAHPs, such as hippocampal pyramidal neurons. The distribution of regions that express mRNA coding for SK2 and SK3 shows similar pattern to the areas, where apamin-sensitive sAHPs have been recorded (Stocker et al., 2000; Kohler et al., 1996; Mourre et al., 1984, 1986). 


\section{HPA axis and learning}

\subsection{HPA axis}

It is already known that the hormones of the hypothalamus-pituitary-adrenal (HPA) axis influence learning and memory process in situations of acute or chronic stress. Animals react in multiple ways to physical or psychological stress. A first rapid reaction is activation of autonomous nervous system (ANS) leading to enhanced catecholamine activity. Adrenalin (epinephrine) and noradrenalin (norepinephrine) from the adrenal medulla produce the typical stress symptoms such as increased heart rate and sweat gland activation. A second, slower response is activation of hypothalamuspituitary-adrenal (HPA) axis. Corticotrophin-releasing hormone (CRH) from the hypothalamus reaches the pituitary, which secretes adrenocorticotrophin (ACTH). $\mathrm{ACTH}$, in turn, stimulates the adrenal cortex to secrete glucocorticoids (GCs, corticosterone in rodents, cortisol in human). Glucocorticoids are lipophilic hormones and can easily pass the blood-brain barrier, where they influence multiple regions of the brain. The effects of GCs are mediated via their specific intracellular receptors or via the interaction of the hormone with neurotransmitter receptors on the cell surface (de Kloet et al., 1998).

Glucocorticoid receptors have been found in several areas of the brain, which are relevant to cognition such as the hippocampus, the amygdala and the prefrontal cortex (Bizon et al., 2001; Silvestrini et al., 2003; Reincke et al., 1998). It has been reported that the hippocampus plays an important role for spatial learning and declarative memory (Eichenbaum et al., 1999; Squire et al., 1992). The amygdala is critical for emotional memory, (LeDoux et al., 2000) and the prefrontal cortex is important for working memory (McGaugh et al., 2002; Baddeley et al., 2001).

\subsection{HPA axis, stress and aging}

The stress-induced secretion of GCs has multiple acute effects in the central nervous system (CNS). Most of the effects in the CNS are mediated via interaction with the two specific intracellular receptors. One is mineralocorticoid receptor (MR or type I receptor), which has high affinity for corticosteroid. The other is glucocorticoid receptor (GR, or type II), which has much lower affinity for corticosteroid (for review, see de 
Kloet, 2003). Because they show quite different binding affinities for corticosteroid, we can easily assume that most of the MR is occupied under basal conditions. GRs can only be activated by high level of GCs as found under stress (de Kloet et al., 1998). Electrophysiological studies have revealed that high levels of GCs reduce neuronal excitability (Joel et al., 2001) and impair synaptic plasticity via a GR-mediated mechanism (Diamond et al., 1992, Pavlides et al., 1996). Acute stress inhibits neurogenesis in the dentate gyrus (Gould et al., 1998) and modulates synaptic spine density in the CA1 region (Shors et al., 2001). The effects of stress are not limited to the hippocampus. In the prefrontal cortex, stress enhances dopaminergic activity (Arnsten et al., 1998) and increases extracellular glutamate levels (Moghaddam et al., 2002).

In some cases like fear conditioning, acute stress has positive effects and improves learning (de Kloet et al., 1998, 1999). It is interesting to note that this learning improvement is associated with increased secretion of corticosterone (Cordero et al., 1998; Sandi et al., 1997; McGaugh et al., 2002; Oitzl et al., 2001)

On the other hand, acute stress impairs spatial learning and memory. If the animals are placed in a stressful condition between the learning paradigm and the subsequent recall, they showed impairment in the hippocampus-mediated spatial memory (Diamonds et al., 1992, 1996; de Quervain et al., 1998). In contrast, stress before the initial learning session seems to have very little or no effect on spatial memory. Thus, the memory enhancing or impairing effects of stress are dependent on the forms of conditioning and on the learning paradigm.

It is important to mention, that most of the studies investigating stress and learning and memory have been performed with young, male animals. Indeed, those studies looking at sex differences found a striking diversity. It has been reported that stress enhances conditioning of male rats, while it impairs it in female rats (Wood and Shors, 1998; Shors et al., 1998). It is also surprising that the learning ability seems to be quite dependent on the level of estrogen, but it does not show a high relationship to the level of corticosterone in female animals (Wood et al., 2001). In addition to sex differences, age also influences the response to acute stress or GC treatment. Aging goes with increases in basal cortisol or cortiscosterone levels and decreases in HPA axis sensitivity (Seeman et al., 1994; van Cauter et al., 1996; Wolf et al., 2002). This 
phenomenon is accompanied by impaired spatial or declarative memory and hippocampal atrophy (Issa et al., 1990; Landfield et al., 1978). Studies in rodents show that preventing the age-associated changes of HPA axis reduced age-related memory impairment (Landfield et al., 1981; Meaney et al., 1991).

\section{Regulation of gene transcription by steroid receptors}

\subsection{Genomic action of steroids}

Steroid hormones play important roles in the regulation of gene expression in higher eukaryotes. When they enter the target cell, steroid hormones can bind to their specific receptors with high affinity. Hormone receptors can regulate transcription as cofactors, when they are activated by their ligands, hormones. Activated steroid receptors can bind their cis-acting elements directly, regulate their transcription initiation or can even affect alternative splicing of mRNA (Auboeuf et al., 2002; McKenna et al., 1999, 2002). Short DNA elements, which bind steroid receptors, are called 'steroid response elements' (SREs).

\subsection{Structure of steroid receptors}

Reported steroid receptors consist of three domains, a variable N-terminal region, a highly conserved central region known as a DNA binding domain and a moderately conserved C-terminal region. The central DNA region has two 'Zn-finger' domains that play an important role in binding DNA. In many steroid receptors, the ligand-binding domain has been localized in the C-terminal region (Carson-Jurica et al., 1990; Conneely et al., 1988). The $\mathrm{N}$-terminal region plays an important role in the differential initiation of target promoters (Kumar et al., 1986; Hollenberg et al., 1987; Rusconi et al., 1987; Tsai et al., 1991; Carson et al., 1987).

\subsection{Mechanism of steroid hormone regulation of target genes}

When steroid hormones enter the target cell, they interact with 8-10S receptor complexes. The 8-10 S complex is composed of the receptor and other proteins such as hsp90, hsp70 and several other proteins (Bagchi et al., 1991; Schowalter et al., 1991). 8$10 \mathrm{~S}$ receptor complexes cannot bind steroid receptor elements, so they are functionally 
inert. Binding of the steroid hormone makes 8 -10S receptor complexes active and these activated receptor complexes dimerize to form $4-5 \mathrm{~S}$ complexes. The receptor dimer is functional, thus it is able to bind to SREs. The receptor-DNA complex can trigger the formation of a stable pre-initiation complex with RNA polymerase II and other transcription factors such as TFIIA, TFIIB, TFIID and TFIIE/F and start RNA synthesis (Tsai et al., 1991; Joab et al., 1984; Sanchez et al., 1985; Schuh et al., 1985; Catelli et al., 1985; Estes et al., 1987, Kost et al., 1989).

Several SREs were reported. A comparison of available sequences indicates that there is a short 13-15 nucleotides consensus sequence for most of the steroid receptor response elements (SREs). This suggests that target genes for receptors have conserved response elements, just as the receptors have conserved DNA binding domains. There are only minor differences among glucocorticoid response elements (GREs), estrogen response elements (EREs) and thyroid response elements (TREs). Most of the glucocorticoid response elements, which bind to the glucocorticoid receptors, can also bind mineralocorticoid, progesterone, and androgen receptors (Tsai et al., 1989; Tsai and O’Malley, 1991). TREs can confer retinoic acid receptor responsiveness (Beato et al., 1996).

\subsection{Role of steroid hormone receptors in target gene transcription}

Steroid hormone regulated cellular promoters are complex and require multiple protein co-factors. It is quite likely that the steroid receptor interacts with a number of core promoter-binding factors, such as RNA polymerase II, TFIID, TFIIA, TFIIB and TFIIE/F, to regulate initiation of transcription (for Review, see Tsai and O'Malley, 1991). For example, in the case of the progesterone receptor (PR), the receptor is essential for

the assembly of such a stable transcription complex. The PR seems to act similar to other regulatory proteins in enhancing the recognition of the promoter by other factors in the transcriptional machinery (Leonhardt et al., 2003).

\subsection{The role of steroid hormones in receptor function}

It is known that the steroid receptors can only bind to their target SREs after hormone treatment. However, several studies have demonstrated that 'purified' receptors 
can also bind to their SREs in a hormone-independent manner (Geisse et al., 1982; Karin et al., 1984; Slater et al., 1985). It is conceivable that the steroid hormone is required to free the receptor from an inhibitor protein but that it does not participate in the actual DNA-binding process. It is reported that the steroid hormone has only little effect on the kinetics and affinity of receptor binding to DNA (Rodriguez et al., 1989; Schauer et al., 1989). For example, even purified PR is able to activate GRE/PRE dependent transcription in the absence of progesterone. In this case, it is believed that ligand binding maybe only required for the early phase of activation when hsp90 or other associated proteins dissociate (Klein-Hitpass et al., 1990).

There is also the possibility of post-translational modification, which is responsible for the stimulation of transcription such as phosphorylation or dephosphorylation (Kuiper et al., 1994).

\subsection{Synergistic interaction of steroid response elements}

In the 5'-flanking regions of hormone responsive genes there are often multiple SREs detectable. When in this case a single SRE is mutated or deleted, the entire level of expression is changed. This suggests, that SREs act synergistically to control the level of expression of a hormone-responsive gene (Tsai et al., 1989). It is also reported that a GRE/PRE can co-operate with an ERE to induce a high level of promoter activity. However, binding studies indicate that estrogen and progesterone receptors do not bind in a co-operative manner, suggesting that additional other mechanisms exist (Tsai et al., 1991).

\section{Nuclear Factor - kappaB}

\subsection{Regulation of NF-kappaB}

It has recently been reported that activation of transcription factor nuclear factor kappaB (NF-kappaB) is associated with neuronal plasticity and anti-apoptotic effects in several cultured neurons. The NF-kappaB complex is composed of three subunits: p50, p65 and the inhibitory subunit IkappaB (IkB). However, since NF-kappaB has first been identified (Sen and Baltimore, 1986), many other binding subunits, which are differently 
expressed depending on cell types, developmental stages and environmental factors have been reported (for review, see Mattson et al., 2000; Verma et al., 1996).

The main molecular event, which activates NF-kappaB is phosphorylation of IkB. IkB proteins bind NF-kappaB p50/p65 complexes in the cytosol and block their activation. Phosphorylation of $\mathrm{IkB}$ dissociates $\mathrm{IkB}$ from the $\mathrm{p} 50 / \mathrm{p} 65$ complex. Subsequently, activated p50/p65 complexes can enter the nucleus and function as a transcription factor (Fig. 1). It has been reported that IkB is phosphorylated by IkB kinase (IKK). IKK is phosphorylated by several kinases such as NF-kappaB-inducing kinase (NIK, Malinin et al., 1997) and mitogen-activated protein kinase kinase kinase-1 (Lee et al., 1998).

Many factors such as cytokines, neurotrophic factors, and neurotransmitters can activate NF-kappaB. (Cheng et al., 1994; Barger et al., 1995; Carter et al., 1996) Activation of glutamate receptors and membrane depolarization was shown to activate NF-kappaB in hippocampal neurons and cerebellar granule neurons. (Guerrini et al., 1995; Kaltschmidt et al., 1995)

Besides many other genes manganese superoxide dismutase (MnSOD) was one of the first reported as a potential target of NF-kappaB (Wong et al., 1989; Mattson et al., 1997). MnSOD is a mitochondrial antioxidant enzyme that protects cells from apoptosis. Other genes, which are induced by NF-kappaB, are tumor necrosis factor-alpha (TNFalpha), interleukins 2,3,6 and 8, IkB-alpha, cyclooxygenase-2 and transglutaminase and NF-kappaB inhibitor IkB. They are expressed in several kinds of cells and many of them are related to apoptosis, which is induced in response to brain injury or stress insults (for review, see Mattson et al., 2000).

NF-kappaB is also essential for the development of the nervous system. The NFkappaB homologue 'dorsal' from drosophila plays a role in the establishment of dorsoventral polarity in the developing embryo (Hoch and Jackle, 1993). Levels of NFkappaB activity change during development of the nervous system. Especially during the early postnatal period when synaptogenesis is actively going on NF-kappaB shows very high expression levels in the rat cerebellum (Kaltschmidt et al., 1995). 


\subsection{Function of NF-kappaB}

Because increased NF-kappaB activity is observed in neurons following seizure and ischemia, NF-kappaB has initially been regarded as apoptosis inducers (Prasade et al., 1994; Grilli et al., 1996; Salminen et al., 1995; Clemens et al., 1997). But recently new interpretations about the function of NF-kappaB have emerged. A lot of reports could demonstrate that NF-kappaB has rather anti-apoptotic function instead of damaging the cells (Goodman and Mattson, 1996; Tamatani, et al., 1999). It has been reported that tumor necrosis factor-alpha (TNF) can activate NF-kappaB, which protects cultured hippocampal neurons from excitotoxic and apoptotic processes as seen during exposure to glutamate, glucose deprivation and amyloid-beta peptide toxicity (Cheng et al., 1994; Barger et al., 1995; Mattson et al., 1997) 


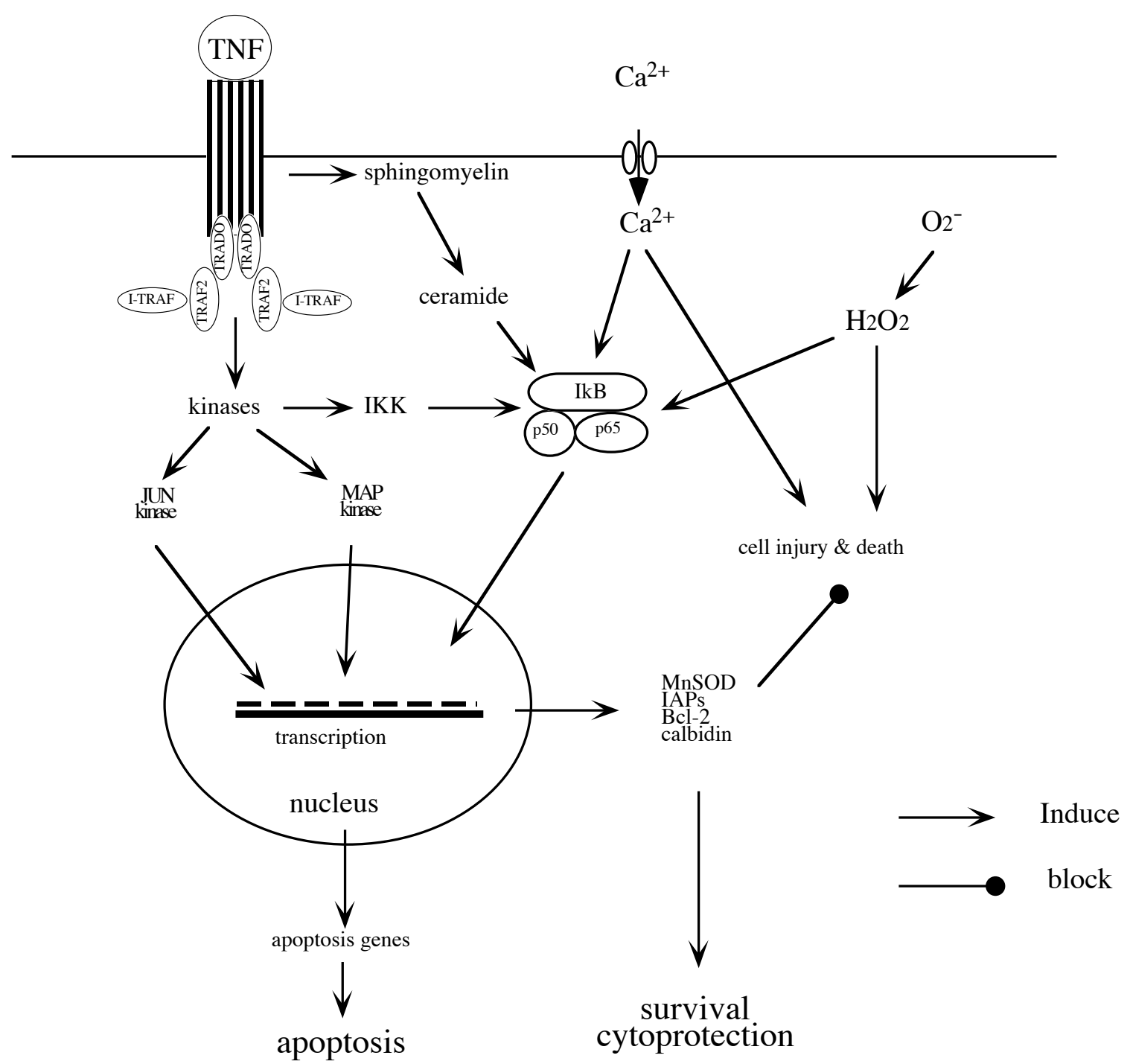

Fig.1 Mechanism of regulation of NF-kappaB activity. Inactivated NF-kappaB complexes are in the cytosol, several factors such as $\mathrm{Ca}^{2+}$, kinases, ceramide and $\mathrm{H}_{2} \mathrm{O}_{2}$ activate them as cellular signals. Activated NF-kappaB complexes enter the nucleus and trigger transcription of specific genes, which induce apoptosis or protect cells from cellular damages. Modified from Mattson et al., 2000.

\subsection{Interaction of NF-kappaB and glucocorticoid receptors}

It has been well described that there is a negative interaction between glucocorticoid receptors and NF-kappaB. Many cases have been reported that activated GR can antagonize the activity of NF-kappaB by direct and indirect mechanisms. First of all, glucocorticoids induce the expression of $\mathrm{IkB}$, which is known as an endogenous and specific NF-kappaB inhibitor (Auphan et al., 1995; Scheinman et al., 1995). In the second case, hormone-activated GR-GRE binding can spatially mask the DNA binding sites of 
other basal and induced transcription factors (Ray and Sehgal, 1992; Akerblom et al., 1988; Mordacq and Linzer, 1989). Furthermore, activated GR can bind NF-kappaB directly and as a result reduce its DNA binding capacity (de Bosscher et al., 1997; Nissen and Yamamoto, 2000). Another possibility is that activated-GR competes with NFkappaB for nuclear co-activators, which are crucial for transcription (Zhang et al., 1997). In any case, activated GRs negatively regulate NF-kappaB activity.

\section{Impact of aging on learning}

\subsection{Anatomical and physiological changes in aged animals}

Although aging is not related to neuropathological diseases like Alzheimer's disease, it is known that normal aging is also associated with a mild impairment of memory (Droscoll et al., 2003; Schumacher et al., 2003) But interestingly, most of the basic cellular characteristics of hippocampal cells such as the resting membrane potential, amplitude and duration of $\mathrm{Na}^{+}$-mediated action potentials, amplitude of $\mathrm{Ca}^{2+}$-mediated action potentials and firing rates in the awake or asleep animals do not changed with age (for review, see Rosenzweig and Barnes, 2003).

One of the important changes in aged animals is the regulation of $\mathrm{Ca}^{2+}$ homeostasis (Foster and Kumar, 2002; Toescu and Verkhratsky, 2000 a, b). It has been reported that the density of functional L-type $\mathrm{Ca}^{2+}$ channels and, in consequence, L-type $\mathrm{Ca}^{2+}$ currents are increased in the hippocampal CA1 region of aged rats (Thibault and Landfield, 1996; Campbell et al., 1998). This is consistent with the report of increased vdccLTP in CA1 pyramidal cells (Shankar et al., 1998). It has been also observed that learning in aged rats in the Morris water maze is negatively correlated with the density of L-type $\mathrm{Ca}^{2+}$ channels (Thibault and Landfield, 1996; Ouanounou et al., 1999). It is also observed that the activities of phosphatase PP1 and PP2A are enhanced with age (Norris et al., 1998). Blockade of both phosphatases enhances synaptic strength in aged rats. Behavioral experiments show that increased PP2A activity is negatively correlated to the performance in the Morris water maze (Norris et al., 1996, 1998; Strack et al., 1997, Foster et al., 2001). 
Several earlier studies show a loss of hippocampal cells with age (for review, see Coleman and Flood, 1987). However, with improved quantification methods these results could not be confirmed (Rapp and Gallagher, 1996; Rassmussen et al., 1996; Calhoun et al., 1998; West et al., 1993; Peters et al., 1996; West, 1993).

Instead, it has been suggested that age-related learning deficits are related to changed connections between cells in the hippocampus. To prove this hypothesis, several methods were adopted such as stereological cell counting methods (Keuker et al., 2003; von Bohlen und Halbach and Unsicker, 2002; Merrill et al., 2000). More recent work examined the amount of synapse-associated proteins. They found no significant changes in the amount of synaptic proteins like synaptophysin, synaptotagmin and synaptosomal associated protein 25 in the entire hippocampus of aged memory-impaired rats (Nicolle et al., 1999).

There are several reports about the changes of functional connectivity in the brains of aged animals. For example, reduced synaptic contacts have been observed in the mid-molecular layer together with decreased field EPSPs in the dentate gyrus (Geinisman et al., 1992; Barnes and McNaughton, 1980; Foster et al., 1991). It has also been reported that the NMDA-receptor mediated EPSP is reduced in the same area (Rao et al., 1994). In contrast to these findings, there is no age-related change in the number of NMDA receptor binding sites (Wenk and Barnes, 2000). This discrepancy obviously shows, that the number of receptors does not necessarily allow for any functional predictions.

\subsection{Age-dependent changes in synaptic plasticity}

\subsubsection{LTP}

Since the last century, it has been believed that synaptic plasticity subserves learning and memory process. Storage of memories certainly changes some form of synaptic modification. About half a century ago, Hebb postulated that, if a presynaptic and a postsynaptic cells fire at the same time, the strength of connection between those two cells will increase (Hebb, 1949). After about 35 years, a long-lasting increase in synaptic strength, which was named long-term potentiation (LTP), was observed in the rabbit dentate gyrus (Bliss and Gardner-Medwin, 1973; Bliss and Lomo, 1973, Douglas and Goddard, 1975). LTP was induced only at the synapse of the stimulated pathway, 
suggesting that LTP is not merely an increase in the strength of all synapses (Levy and Steward, 1979). This result suggests, that LTP might be a cellular phenomenon underlying memory processes.

The most intensively studied form of LTP is NMDA receptor-dependent (Collingridge et al., 1983; Bliss and Collingridge, 1993). If glutamate is released from the presynaptic site, it can bind to postsynaptic NMDA and AMPA receptor channels. Initially, AMPA receptor channels are opened, whereas NMDA receptor channels are blocked by $\mathrm{Mg}^{2+}$ (Kato et al., 1991; Psarropoulou and Kostopoulous, 1990). Open AMPA receptor channels depolarize the membrane, which allows NMDA receptor channels to flux $\mathrm{Ca}^{2+}$ into the cell. The $\mathrm{Ca}^{2+}$ influx induces a cascade of events, which result in durable LTP (Gustafsson and Wigstroem, 1988; Bliss and Collingridge, 1993; Malenka and Nicoll, 1993; Rosenzweig and Barnes, 2003). There are reports that LTP induces the increase of postsynaptic AMPA receptor channels (Lynch and Baudry, 1984; Issac et al., 1995; Liao et al., 1995; Shi et al., 1999; Hayashi et al., 2000; Heynen et al., 2000). In the presence of more postsynaptic AMPA receptor channels, the same amount of glutamate can easily trigger a larger depolarization (Malenka and Nicoll, 1999; Luscher et al., 2000; Luscher and Frerking 2001; Lisman et al., 2002; Malinow and Malenka, 2002).

\subsubsection{Age-related changes in LTP}

There are conflicting data on the link between LTP and learning and memory (for review, see Cain 1997; Martin et al., 2000). However, the vast majority of studies show a positive correlation. For example, it has been reported that saturation of LTP disrupts recently acquired memory and prevents the formation of new memories (McNaughton et al., 1986; Castro et al., 1989; Moser et al., 1998). Blocking LTP can also prevent the formation of new memories (Fanselow and Kim, 1994; Mayford et al., 1996; Tonegawa et al., 1996; Tsien et al., 1996).

It is not clear whether impaired LTP is responsible for age-related memory deficits, because age-related changes in LTP are only observed under specific experimental conditions (for review, see Rosenzweig and Barnes, 2003). In most studies, aged-animals have intact hippocampal LTP when the cells are stimulated with high frequency (Landfield and Lynch, 1977; Barnes, 1979; Diana et al., 1994; Chang et al., 
1991; Deupree et al., 1991; Moore et al., 1993). But interestingly, when aged animals are stimulated with fewer stimulus pulses and lower intensity, they show reduced LTP in the hippocampal CA1 area (Deupree et al., 1993; Moore et al., 1993; Rosenzweig et al., 1997). It has to be mentioned, that aged-animals show deficits not only in LTP induction but also in LTP maintenance. It has been reported that after LTP induction, LTP decays faster in aged than in young animals (Barnes and McNaughton, 1980; Bach et al., 1999).

\section{Aims of this study}

SK channels are believed to contribute to the generation of AHPs in hippocampal neurons. In hippocampal CA1 neurons glucocorticoids induce an increase in the amplitude of the AHP following a short current pulse (Karst and Joels, 1991). Since this change of membrane properties can be prevented by the protein synthesis inhibitor cycloheximide, a genomic action of glucocorticoids can be assumed. Thus, it is conceivable that the expression of SK channels can be altered by changing corticosteroid levels as observed during stress and aging (Lupien et al., 1994; Ling and Jamali, 2003). Because it has been reported that SK2 channels have neuroprotective effects in cultured cells (Lee et al., 2003), it can be assumed that expression of SK2 channels is regulated by transcription factors, which are associated with neuroprotection. NF-kappaB represents a transcriptional modulator, which can either induce apoptosis or protect cells from the cellular damage of oxidative stress, depending on the cellular context. In the present study, my first goal was to clarify the regulatory mechanism of SK channel gene expression in vivo and in vitro. The second aim of this study was to understand the contribution of single SK channel subtypes to cognitive processes and synaptic plasticity. So far, the precise functional role of each SK channel subtype in specific neuronal pathways has been difficult to elucidate because of the absence of selective blockers. The use of selective antisense probes against single SK channel subtypes made it possible to overcome the lack of specific antagonists. With this approach, especially the role of SK3 channels in the modulation of hippocampal synaptic plasticity and hippocampaldependent memory encoding was investigated. 


\section{References}

Agopyan $\mathrm{N}$ and Agopyan I Effects of protein kinase $\mathrm{C}$ activators and inhibitors on membrane properties, synaptic responses, and cholinergic actions in CA1 subfield of rat hippocampus in situ and in vitro Synapse (1991) 7: 193- 206

Akerblom IE, Slater EP, Beato M, Baxter JD and Mellon PL Negative regulation by glucocorticoids through interference with a cAMP responsive enhancer Science. (1988) 241: 350- 353

Almawi WY and Melemedjian OK Negative regulation of nuclear factor kappaB activation and function by glucocorticoids J Mol Endocrinol. (2002) 28: 69- 78

Arnsten AF and Goldman-Rakic PS Noise stress impairs prefrontal cortical cognitive function in monkeys: evidence for hyperdopaminergic mechanism Arch. Gen. Psychiatry (1998) 55:362-368

Auboeuf D, Honig A, Berget SM and O'Malley BW Coordinate regulation of transcription and splicing by steroid receptor coregulators Science (2002) 298: 416-419

Auphan N, DiDonato JA, Rosette C, Helmberg A and Karin M Immunosuppression by glucocorticoids: inhibition of NF-kappa B activity through induction of I kappa B synthesis Science (1995) 270: 286290

Axelson DA, Doraiswamy PM and McDonald WM Hypercortisolemia and hippocampal changes in depression Psychi. Res. (1993) 47: 163- 173

Bach ME, Barad M, Son H, Zhou M, Lu YF, Shih R, Mansuy I, Hawkins RD and Kandel ER Age-related defects in spatial memory are correlated with defects in the late phase of hippocampal long-term potentiation in vitro and are attenuated by drugs that enhance the cAMP signaling pathway Proc. Natl. Acad. Sci. USA (1999) 96: 5280- 5285

Baddeley AD Is working memory still working? American Psychologists (2001) 56: 851-864

Bagchi MK, Tsai SY, Tsai MJ and O'Malley BW Progesterone enhances target gene transcription by receptor free of heat shock proteins hsp90, hsp56, and hsp70 Mol Cell Biol. (1991) 11: 4998- 5004

Bardgett ME, Taylor GT and Csernansky JG Chronic corticosterone treatment impairs spontaneous alternation behavior in rats Behav. Neural Biology (1994) 61: 186- 190

Barger SW, Horster D, Furukawa K, Goodman Y Krieglestein J and Mattson MP Tumor necrosis factors alpha and beta protect neurons against amyloid beta-peptide toxicity: evidence for involvement of a kappaB-binding factor and attenuation of peroxide and Ca2+ accumulation (1995) Proc Natl Acad Sci USA 92: 9328- 9332

Barnes CA Memory deficits associated with senescence: a neurophysiological and behavioral study in the rat J. Comp. Physiol. Psychol. (1979) 93: 74- 104

Barnes CA Do synaptic markers provide a window on synaptic effectiveness in the aged hippocampus? Neurobiol. Aging (1999) 20: 349- 351

Barnes CA and McNaughton BL Physiological compensation for loss of afferent synapses in rat hippocampal granule cells during senescence J. Physiol. (London) (1980) 309: 473- 485

Barnes CA, Rao G and McNaughton BL Functional integrity of NMDA-dependent LTP induction mechanisms across the lifespan of F344 rats Learn. Mem. (1996) 3: 124- 137 
Barnes CA, Rao G, Foster TC, and McNaughton BL Region-specific age effects on AMPA sensitivity: electrophysiological evidence for loss of synaptic contacts in hippocampal field CA1 Hippocampus (1992) 2: 457- 468

Barnes CA, Rao G, and Orr G Age-related decrease in the Schaffer collateral-evoked EPSP in awake, freely behaving rats Neural Plast. (2000) 7: 167- 178

Beato M, Chavez S and Truss M Transcriptional regulation by steroid hormones Steroids (1996) 61: 240-251

Bekkers JM Distribution of slow AHP channels on hippocampal CA1 pyramidal neurons J. of Neurophysiol. (2000) 83: 1756- 1759

Belanoff JK, Kalehzan M, Sund B, Fleming Ficek SK and Schatzberg AF Cortisol activity and cognitive changes in psychotic major depression Am J Psychiatry (2001) 158: 1612- 1616

Bizon JL, Helm KA, Han JS, Chun HJ, Pucilowska J, Lund PK and Gallagher M Hypothalamic-pituitaryadrenal axis function and corticosterone receptor expression in behaviourally characterized young and aged Long-Evans rats Eur J Neurosci. (2001) 14: 1739- 1751

Blank T, Nijholt I, Grammatopoulos DK, Randeva HS, Hillhouse EW and Spiess J Corticotropinreleasing factor receptors couple to multiple G-proteins to activate diverse intracellular signaling pathways in mouse hippocampus: role in neuronal excitability and associative learning $J$ Neurosci. (2003) 230: 700- 707

Blatz AL and Magleby KL Single apamin-blocked Ca-activated K+ channels of small conductance in cultured rat skeletal muscle Nature (1986) 323: 718- 720.

Blatz AL and Magleby KL Correcting single channel data for missed events Biophys J. (1986) 49: 967980

Bliss TVP and Collingridge GL A synaptic model of memory: long-term potentiation in the hippocampus Nature (1993) 361: 31- 39

Bliss TVP and Gardner-Medwin AR Long-lasting potentiation of synaptic transmission in the dentate area of the unanaesthetized rabbit following stimulation of the perforant path J. Physiol. (London) (1973) 232: 357- 374

Bliss TVP and Lomo T Long-lasting potentiation of synaptic transmission in the dentate area of the anaesthetized rabbit following stimulus of the perforant path J. Physiol. (London) (1973) 232: 331- 356

Bodnoff SR, Humphreys AG and Lehman JC Enduring effects of chronic corticosterone treatment on spatial learning, synaptic plasticity, and hippocampal neurophathology in young and mid-aged rats J. Neurosci. (1995) 15: 61-69

Bond CT, Maylie J, and Adelman JP Small-conductance calcium-activated potassium channels Ann N Y Acad Sci. (1999) 370-378

Bourdeau I, Bard C, Noel B, Leclerc I, Cordeau MP, Belair M, Lesage J, Lafontaine L and Lacroix A Loss of brain volume in endogenous Cushing's syndrome and its reversibility after correction of hypercortisolism J Clin Endocrinol Metab. (2002) 87: 1949- 1954.

Bowden SE, Fletcher S, Loane DJ and Marrison NV Somatic colocalization of rat SK1 and D class (Cav 1.2) L-type calcium channels in rat CA1 hippocampal pyramidal neurons J. Neurosci. (2001) 21: 1-6 
Bowman RE, Ferguson D and Luine VN Effect of chronic restraint stress and estradiol on open field activity, spatial memory, and monoaminergic neurotransmitter in ovariectomized rats Neuroscience (2002) 110: 401- 410

Bowman RE, Zrull MC and Luine VN Chronic restraint stress enhances radical arm maze performance in female rats Brain Res. (2001) 904: 279- 289

Cain DP LTP, NMDA, genes and learning Curr. Opin. Neurobiol. (1997) 7: 235-242

Calhoun ME, Kurth D, Phinney AL, Long JM, Hengemihle J, Mouton PR, Ingram DK and Jucker M Hippocampal neuron and synaptophysin-positive bouton number in aging C57BL/6 mice Neurobiol. Ading (1998) 19: 599- 606

Campbell LW, Hao SY, Thibault O, Blalock EM and Landfield PW Aging changes voltage-gated calcium currents in hippocampal CA1 neurons J. Neurosci. (1996) 16: 6286- 6295

Carson-Jurica MA, Schrader WT and O'Malley BW Steroid receptor family: structure and functions Endocr Rev. (1990) 11: 201- 220

Carson MA, Tsai MJ, Conneely OM, Maxwell BL, Clark JH, Dobson AD, Elbrecht A, Toft DO, Schrader WT and O'Malley BW Structure-function properties of the chicken progesterone receptor A synthesized from complementary deoxyribonucleic acid Mol Endocrinol. (1987) 11: 791-801

Carter BD, Kaltschmidt C, Kaltschmidt B, Offenhauser N, Bohm-Matthaei R, Baeuerle PA, and Barde YA Selective activation of NF-kappaB by nerve growth factor through the neurotrophin receptor $\mathrm{p} 75$ (1996) Science 272: 542- 545

Castro CA, Sil LH, McNaughton BL and Barnes CA Recovery of spatial learning deficits after decay of electrically induced synaptic enhancement in the hippocampus Nature (1989) 342: 545- 548

Catelli MG, Binart N, Jung-Testas I, Renoir JM, Baulieu EE, Feramisco JR and Welch WJ The common 90-kd protein component of non-transformed ' $8 \mathrm{~S}$ ' steroid receptors is a heat-shock protein EMBO Journal (1985) 4: 3131-3135

Chang FLF, Isaacs KR and Greenough WT Synapse formation occurs in association with the induction of long-term potentiation in two-year-old rat hippocampus in vitro Neurobiol. Aging (1991) 12: 517 522

Cheng B, Christakos S and Mattson MP Tumor necrosis factors protect neurons against metabolicexcitotoxic insults and promote maintenance of calcium homeostasis Neuron (1994) 12: 139- 153

Clark RE and Squire LR Classical conditioning and brain systems: the role of awareness Science (1998) 280: 77- 81

Clemens JA, Stephenson DT, Dixon EP, Smalstig EB, Mincy RE, Rash KS and Little SP Global cerebral ischemia activates nuclear factor-kappa $B$ prior to evidence of DNA fragmentation Brain Res Mol Brain Res. (1997) 48: 187- 196

Clemens JA, Stephenson DT, Smalstig EB, Dixon EP and Little SP Global ischemia activates nuclear factor-kappa B in forebrain neurons of rats Stroke (1997) 28: 1073-80

Cohen AS, Coussens CM, Raymond CR and Abraham WC Long-lasting increase in cellular excitability associated with the priming of LTP induction in rat hippocampus J. Neurophysiol. (1999) 82: 31393148 
Cole AE and Nicoll RA, The pharmacology of cholinergic excitatory response in hippocampal pyramidal cells Brain Res. (1984) 305: 283- 290

Coleman PD and Flood DG Neuron numbers and dendritic extent in normal aging and Alzheimer's disease Neurobiol Aging. 1987 8: 521- 545

Colino A and Halliwell JV Differential modulation of three separate K-conductances in hippocampal CA1 neurons by serotonin Nature (1987) 328: 73- 77

Collingridge GL, Kehl SJ and McLennan H Excitatory amino acids in synaptic transmission in the Scheffer collateral-commissural pathway of the rat hippocampus J. Physiol. (London) (1983) 334: 3346

Conneely OM, Dobson AD, Carson MA, Maxwell BL, Tsai MJ, Schrader WT and O'Malley BW Structure-function relationships of the chicken progesterone receptor Biochem Soc Trans. (1988) 16: 683- 687

Conrad CD, Galea LA, Kuroda Y and McEwen BS Chronic stress impairs rat spatial memory on the $\mathbf{Y}$ maze, and this effect is blocked by tianeptine pretreatment Behav. Neurosci. (1996) 110: 1321- 1334

Conrad CD and Roy EJ Selective loss of hippocampal granule cells following adrenalectomy: implications for spatial memory J Neurosci. (1993) 13: 2582- 2590

Cordero MI, Merino JJ and Sandi C Correlational relationship between shock intensity and corticosterone secretion on the establishment and subsequent expression of contextual fear conditioning Behav. Neurosci. (1998) 112: 885-891

Czeh B, Michaelis T and Watanabe T Stress-induced changes in cerebral metabolites, hippocampal volume, and cell proliferation are prevented by antidepressant treatment with tianeptine Proc. Natl. Acad. Sci. USA (2001) 98: 12796-12801

de Bosscher K, Schmitz ML, Vanden Berghe W, Plaisance S, Fiers W and Haegeman G Glucocorticoidmediated repression of nuclear factor-kappaB-dependent transcription involves direct interference with transactivation Proc Natl Acad Sci U S A. (1997) 94: 13504- 13509

de Leon MJ, McRae T and Tsai JR Abnormal cortisol response in Alzheimer's disease linked to hippocampal atrophy Lancet (1998) ii: 391-392

de Kloet ER Hormones, brain and stress Endocr Regul. (2003) 37: 51- 68

de Kloet ER, Oitzl MS and Joels M Stress and cognition: are corticosteroids good or bad guys? Trends Neurosci. (1999) 22: 422- 466

de Kloet ER, Vreugdenhil E, Oitzl MS and Joels M Brain corticosteroid receptor balance in health and disease Endocr Rev. (1998) 19: 269-301

de Quervain DJ, Roozendaal B and McGaugh JL Stress and glucocorticoids impair retrieval of lingterm spatial memory Nature (1998) 394: 787-790

Deupree DL, Bradley $\mathrm{J}$ and Turner DA Age-related alterations in potentiation in the CA1 region in F344 rats Neurobiol. Aging (1993) 14: 249- 258

Deupree DL, Turner DA and Waters CL Spatial performance correlates with in vitro potentiation in young and aged Fischer 344 rats Brain Res. (1991) 554: 1-9 
Deyo RA, Straube $\mathrm{K}$ and Disterhoft JF Nimodipine facilitates associative learning in aging rabbits Science (1989) 243: 809- 811

Diamond DM, Bennett MC, Fleshner M and Rose GM Inverted-U relationship between the level of peripheral corticosterone and the magnitude of hippocampal primed burst potentiation Hippocampus (1992) 2: 421-431

Diamond DM, Fleshner M, Ingersoll N and Rose GM Psychological stress impairs spatial working memory: relevance to electrophysiological studies of hippocampal function Behav Neurosci. (1996) 110: 661-672

Diana G, Domenici MR, Loizzo A, Scotti de Carolis A and Sagratella S Age and strain differences in rat place learning and hippocampal dentate gyrus frequency-potentiation Neurosci, Lett. (1994) 171: 113116

Diana G, Scotti de Carolis A, Frank C, Domenici MR and Sagratella S Selective reduction of hippocampal dentate frequency potentiation in aged rats with impaired place learning Brain Res. Bull. (1994) 35: 107-111

Douglas RM and Goddard GV Long-term potentiation of the perforant path-granule cell synapse in the rat hippocampus Brain Res. (1975) 86: 205- 215

Driscoll I, Hamilton DA, Petropoulos H, Yeo RA, Brooks WM, Baumgartner RN and Sutherland RJ The aging hippocampus: cognitive, biochemical and structural findings Cereb Cortex (2003) 13: 13441351

Dutar P and Nicoll RA, Pharmacological characterization of muscarinic responses in rat hippocampal pyramidal cells EXS (1989) 57: 68- 76

Eichenbaum H A cortical-hippocampal system for declative memory Nat Rev Neurosci. (2000) 1: 41-50

Eichenbaum H The long and winding road to memory consolidation Nat Neurosci. (2001) 4: 1057-1058

Eichenbaum H, Dudchenko P and Wood E The hippocampus, memory, and place cells: it spatial memory or a memory space? Neuron (1999) 23: 209-226

Estes PA, Suba EJ, Lawler-Heavner J, Elashry-Stowers D, Wei LL, Toft DO, Sullivan WP, Horwitz KB and Edwards DP Immunologic analysis of human breast cancer progesterone receptors. 1. Immunoaffinity purification of transformed receptors and production of monoclonal antibodies Biochemistry (1987) 26: 6250- 6262

Fanselow MS and Kim JJ Acquisition of contextual Pavlovian fear conditioning is blocked by application of an NMDA receptor antagonist D,L-2-amino-5-phosphonovaleric acid to the basolateral amygdala Behav. Neurosci. (1994) 108: 210- 212

Foster TC Involvement of hippocampal synaptic plasticity in age-related memory decline Brain Res. Brain Res. Rev. (1999) 30: 236- 249

Foster TC, Barnes CA, Rao G and McNaughton BL Increase in perforant path quantal size in aged F344 rats Neurobiol. Aging (1991) 12: 441- 488

Foster TC and Kumar A Calcium dysregulation in the aging brain Neuroscientist. (2002) 8: 297- 301

Foster TC, Sharrow KM, Massse JR, Norris CM and Kumar A Calcineurin links Ca2+ dysregulation with brain aging J. Neurosci. (2001) 21: 4066- 4073 
Geinisman Y, de Toledo-Morrell L, Morrell F, Persina IS and Rossi M Age-related loss of axospinous synapses formed by two afferent systems in the rat dentate gyrus as revealed by the unbiased stereological dissector technique Hippocampus (1992) 2: 437- 444

Geinisman Y, de Toledo-Morrell L, Morrell $\mathrm{F}$ and Heller RE Hippocampal markers of age-related memory dysfunction: behavioral, electrophysiological and morphological perspectives Prog. Neurobiol. (1995) 45: 223- 252

Geisse S, Scheidereit C, Westphal HM, Hynes NE, Groner B and Beato M Glucocorticoid receptors recognize DNA sequences in and around murine mammary tumour virus DNA EMBO Journal (1982) 1: $1613-1619$

Gold PW, Drevets W, Charney D and Drevets W, New insights into the role of cortisol and the glucocorticoid receptor in severe depression Biol Psychitry (2002) 52: 381

Goodman Y and Mattson MP Ceramide protects hippocampal neurons against excitotoxic and oxidative insults, and amyloid beta-peptide toxicity J Neurochem. (1996) 66: 869- 872

Gorelova $\mathrm{N}$ and Reiner PB Role of the afterhyperpolarization in control of discharge properties of septal cholinergic neurons in vitro J Neurophysiol. (1996) 75: 695- 706

Gould E, Tanapat $\mathrm{P}$ and McEwen BS Proliferatioin of granule cell precursors in the dentate gyrus of adult monkeys is diminished by stress Proc. Natl. Acad. Sci. USA (1998) 95: 3168-3171

Graves CA and Solomon PR Age-related disruption of trace but not delay classical conditioning of the rabbit's nictitating membrane response Behav. Neurosci. (1985) 99: 88- 96

Grilli M, Pizzi M, Memo $\mathbf{M}$ and Spano $\mathbf{P}$ Neuroprotection by aspirin and sodium salicylate through blockade of NF-kappaB activation Science (1996) 274: 1383- 1385

Grover LM and Teyler TJ N-Methyl-D-aspartate receptor-independent long-term potentiation in area CA1 of rat hippocampus: input-specific induction and preclusion in a non-tetanized pathway Neuroscience (1992) 49: 7- 11

Grover LM and Teyler TJ Activation of NMDA receptors on hippocampal area CA1 by low and high frequency orthodromic stimulation and their contribution to induction of long-term potentiation Synapse (1994) 16: 66- 75

Guerrini L, Blasi F and Denis-Donini S Synaptic activation of NF-kappa B by glutamate in cerebellar granule neurons in vitro Proc Natl Acad Sci USA (1995) 92: 9077- 9081

Gustafsson B and Wigstroem H Physiological mechanisms underlying long-term potentiation Trends Neurosci. (1988) 11: 156- 162

Haas HL and Gahwilder BH Vasoactive intestinal polypeptide modulates neuronal excitability in hippocampal slices of rats Neuroscience (1992) 47: 273- 277

Haars HL and Greene RW Adenosine enhances afterhyperpolarization and accommodation in hippocampal pyramidal cells Pflugers Arch. (1984) 402: 244- 247

Haas HL and Greene RW Effects of histamine on hippocampal pyramidal cells of the rat in vitro Exp. Brain Res. (1986) 62: 123- 130

Haas HL and Konnerth A Histamine and noradrenaline decrease calcium-activated potassium conductance in hyppocampal pyramidal cells Nature (1983) 302: 432- 434 
Haug $\mathrm{T}$ and Storm JF Protein kinase A mediates the modulation of the slow Ca2+-dependent K+ current, I (sAHP), by the neuropeptides CRF, VIP, and CGRP in hippocampal pyramidal neurons J Neurophysiol. (2000) 83: 2071- 2179

Hayashi Y, Shi SH, Estenban JA, Piccini A, Poncer JC and Malinow R Driving AMPA receptors into synapses by LTP and CaMKII: requirement for GluR1 and PDZ domain interaction Science (2000) 287: 2262- 2267

Hebb DO The organization of Behavior, Wiley, New York, (1949)

Heynen AJ, Abraham WC and Bear MF Bidirectional modification of CA1 synapses in the adult hippocampus in vivo Nature (1996) 381: 163- 166

Hille B Ionic channels of Excitable Membranes Sinauer Assoviates Sunderland MA (1992)

Hoch M and Jackle H Transcriptional regulation and spatial patterning in Drosophila (1993) Curr Opin Genet Dev. 3: 566- 573

Hollenberg SM, Giguere V, Segui P and Evans RM Colocalization of DNA-binding and transcriptional activation functions in the human glucocorticoid receptor Cell (1987) 49: 39-46

Huerta PT, Sun LD, Wilson M, and Tonegawa S Formation of temporal memory requires NMDA receptors within CA1 pyramidal neurons Neuron (2000) 25:473-380

Issac JTR, Nicoll RA and Malenka RC Evidence for silent synapses: implications for the expression of LTP Neuron (1995) 15: 427- 434

Issa AM, Rowe W, Gauthier S and Meaney MJ, Hypothalamic-pituitary-adrenal activity in aged, cognitively impaired and cognitively unimpaired rats J Neurosci. (1990) 10: 3247- 3254

Joab I, Radanyi C, Renoir M, Buchou T, Catelli MG, Binart N, Mester J and Baulieu EE Common nonhormone binding component in non-transformed chick oviduct receptors of four steroid hormones Nature (1984) 308: 850-853

Joels M Corticosteroid actions in the hippocampus J Neuroendocrinol. (2001) 13: 657-669

Kaltschmidt C, Kaltschmidt B and Baeuerle PA Stimulation of ionotropic glutamate receptors activates transcription factor NF-kappa B in primary neurons Proc Natl Acad Sci USA. (1995) 92: 9618- 9622

Karin M, Haslinger A, Holtgreve H, Richards RI, Krauter P, Westphal HM and Beato M Characterization of DNA sequences through which cadmium and glucocorticoid hormones induce human metallothionein-IIA gene Nature (1984) 308: 513- 519

Kato K, Uruno K, Saito K and Kato H Both arachidonic acid and 1-oleoyl-2-acetyl glycerol in low magnesium solution induce long-term potentiation in hippocampal CA1 neurons in vitro Brain Res. (1991) 563: 94-100

Kerr DS, Campbell LW, Applegate MD, Brodish A and Landfield PW Chronic stress-induced acceleration of electrophysiologic and morphomeric biomarkers of hippocampal aging J. Neurosci. (1991) 11: 1316- 1326

Keuker JI, Luiten PG and Fuchs E Preservation of hippocampal neuron numbers in aged rhesus monkeys Neurobiol Aging (2003) 24: 157- 165 
Klein-Hitpass L, Tsai SY, Weigel NL, Allan GF, Riley D, Rodriguez R, Schrader WT, Tsai MJ and $\mathrm{O}$ 'Malley $\mathrm{BW}$ The progesterone receptor stimulates cell-free transcription by enhancing the formation of a stable preinitiation complex Cell (1990) 60: 247- 257

Kohler M, Hirschberg B, Bond CT, Kinzie JM, Marrion NV, Maylie J and Adelman JP Smallconductance, calcium-activated potassium channels from mammalian brain Science (1996) 20: 17091714

Kost SL, Smith DF, Sullivan WP, Welch WJ and Toft DO Binding of heat shock proteins to the avian progesterone receptor Mol Cell Biol. (1989) 9: 3829- 3838

Krugers HJ, Douma BR, Andringa $G$ et al. Exposure to chronic psychosocial stress and corticosterone in the rats: effects on spatial discrimination learning and hippocampal protein kinase Cgamma immunoreactivity Hippocampus (1997) 7: 427- 436

Kuiper GG and Brinkmann AO Steroid hormone receptor phosphorylation: is there a physiological role? Mol Cell Endocrinol. (1994) 100: 103- 107

Kumar V, Green S, Staub A and Chambon P Localisation of the oestradiol-binding and putative DNAbinding domains of the human oestrogen receptor EMBO Journal (1986) 9: 2231- 2236

Lancaster B and Adams PR Calcium-dependent current generating the afterhyperpolarization of hippocampal neurons J Neurophysilol. (1986) 55: 1268- 1282

Landfield PW and Lynch G Impaired monosynaptic potentiation in in vitro hippocampal slices from aged, memory-deficient rats J. Gerontol. (1977) 32: 523- 533

Landfield PW, Waymire JC and Lynch G Hippocampal ageing and adrenocorticoids: quantitative correlations Science (1978) 202: 1098- 1102

Landfield PW, Baskin RK and Pitler TA Brain ageing correlates: retardation by hormonalpharmacological treatment Science (1981) 214: 581- 584

LeDoux JE Emotion circuits in the brain Ann Rev Neurosci. (2000) 23: 155-184

Lee AL, Dumas TC, Tarapore PE, Webster BR, Ho DY, Kaufer D and Sapolsky RM Potassium channel gene therapy can prevent neuron death resulting from necrotic and apoptotic insults $J$ Neurochem. (2003) 86: 1079- 1088

Lee FS, Peters RT, Dang LC and Maniatis T MEKK1 activates both IkappaB kinase alpha and IkappaB kinase beta (1998) Proc Natl Acad Sci U S A. 95: 9319- 1924

Lee WS, Ngo-Anh TJ, Bruening-Wright A, Maylie J and Adelman JP Small conductance Ca2+-activated K+ channels and calmodulin: cell surface expression and gating J Biol Chem (2003) 278: 25940- 25946

Levy WB and Steward O Synapses as associative memory elements in the hippocampal formation Brain Res. (1979) 175: 233- 245

Leonhardt SA, Boonyaratanakornkit V and Edwards DP Progesterone receptor transcription and nontranscription signaling mechanisms Steroids (2003) 68: 761- 770

Liao D, Hessler NA and Malinow R Activation of postsynaptically silent synapse during LTP in CA1 region of hippocampal slices Nature (1995) 375: 400- 404 
Ling S and Jamali F Effect of cannulation surgery and restraint stress on the plasma corticosterone concentration in the rat: application of an improved corticosterone HPLC assay J Pharm Pharm Sci. (2003) 6: 246- 251

Lorenzon NM and Foehring RC Relationship between repetitive firing and afterhyperpolarization in human neocortical neurons J Neurophysiol. (1992) 67: 350- 363

Lorenzon NM and Foehring RC The ontogeny of repetitive firing and its modulation by norepinephrine in rat neocortical neurons Dev Brain Res. (1993) 73: 213- 223

Luine VN, Spencer RL and McEwen BS Effect of chronic corticosterone ingestion on spatial memory performance and hippocampal serotonergic function Brain Res. (1993) 616: 65- 70

Lupien S, Lecours AR, Lussier I, Schwartz G, Nair NP and Meaney MJ Basal cortisol levels and cognitive deficits in human aging J Neurosci. (1994) 14: 2893- 2903

Luscher C, Nicoll RA, Malenka RC and Muller D Synaptic plasticity and dynamic modulation of the postsynaptic membrane Nat. Neurosci. (2000) 3: 545- 550

Luscher $\mathrm{C}$ and Frerking M Restless AMPA receptors: implications for synaptic transmission and plasticity Trands Neurosci. (2001) 24: 665- 670

Lynch G and Baudry M The biochemistry of memory: a new and specific hypothesis Science (1984) 224: $1057-1063$

Lynch MA and Voss KL Membrane arachidonic acid concentration correlates with age and induction of long-term potentiation in the dentate gyrus of the rat Eur. J. Neurosci. (1994) 6: 1008- 1014

Madison DV, Lancaster B and Nicoll RA Voltage clamp analysis of cholinergic action in the hippocampus J. Neurosci. (1987) 7: 733- 741

Madison DV and Nicoll RA Control of the repetitive discharge of rat CA1 pyramidal neurons in vivo J Physiol. (1984) 354: 319-331

Madison DV and Nicoll RA Action of noradrenaline recorded intracellularly in rat hippocampal CA1 pyramidal neurons, in vitro J. Physiol. (1986) 372: 221- 244

Makino S, Hashimoto K and Gold PW Multiple feedback mechanisms activating corticotrophinreleasing hormone system in the brain during stress Pharmacol Biochem Behav. (2002) 73: 147-158

Malenka RC, Kauer JA, Perkel DJ, Mauk MD, Kelly PT, Nicoll RA and Waxham MN An essential role for postsynaptic calmodulin and protein kinase activity in long-term potentiation Nature (1989) 340: 554- 557

Malenka RC, Madison DV, Andrade R and Nicoll RA Phorbol esters mimic some cholinergic actions in hyppocampal neurons J. Neurosci. (1996) 6: 475- 480

Malenka RC and Nicoll RA Dopamine decreases the calcium-activated afterhyperpolarization in hippocampal CA1 pyramidal cells Brain Res. (1986) 3799: 210 -215

Malenka RC and Nicoll RA NMDA-receptor-dependent synaptic plasticity: multiple forms and mechanisms Trends Neurosci. (1993) 12: 521- 527

Malenka RC and Nicoll RA Long-term potentiation- a decade of progress? Science (1999) 285: 18701874 
Malinin NL, Boldin MP, Kovalenko AV and Wallach D MAP3K-related kinase involved in NF-kappaB induction by TNF, CD95 and IL-1 Nature (1997) 385: 540- 544

Malinow R and Malenka RC AMPA receptor trafficking and synaptic plasticity Annu Rev. Neurosci. (2002) 25: 103- 126

Malinow R, Madison DV and Tsien RW Persistent protein kinase activity underlying long-term potentiation Nature (1988) 335: 820- 824

Malinow R, Schulman H and Tsien RW Inhibition of postsynaptic PKC or CaMKII blocks induction but not expression of LTP Science (1989) 862- 865

Martin SJ, Grimwood PD and Morris RG Synaptic plasticity and memory: an evaluation of the hypothesis Annu. Rev. Neurosci. (2000) 23: 649- 711

Mattson MP, Culmsee C, Yu Z and Camandola S Roles of nuclear factor kappaB in neuronal survival and plasticity J Neurochem. (2000) 74: 443- 456

Mattson MP, Goodman Y, Luo H, Fu W and Furukawa K Activation of NF-kappaB protects hippocampal neurons against oxidative stress-induced apoptosis: evidence for induction of manganese superoxide dismutase and suppression of peroxynitrite production and protein tyrosine nitration J Neurosci Res. (1997) 49: 681- 697

Mayford M, Bach ME, Huang YY, and Wang L, Hawkins RD and Kandel ER Control of memory formation through regulated expression of a CaMKII transgene Science (1996) 274: 1678- 1683

Maylie J, Bond CT, Herson PS, Lee WS and Adelman JP Small Conductance Ca2+-activated K+ Channels and Calmodulin J Physiol. (2003) 18

McGahon BM, Clements MP and Lynch MA The ability of aged rats to sustain long-term potentiation is restored when the age-related decrease in membrane arachidonic acid concentration is reversed Neuroscience (1997) 81: 9- 16

McGahon BM, Maguire C, Kelly A and Lynch MA Activation of p42 mitogen-activated protein kinase by arachidonic acid and trans-1-amino-cyclo-pentyl-1,3-dicarboxylate impacts on long-term potentiation in the dentate gyrus in the rat: analysis of age-related changes Neuroscience (1999) 90: 1167- 1175

McGahon BM, Martin DSD, Horrobin DF and Lynch MA Age-related changes in synaptic function: analysis of the effect of dietary supplementation with omega-3 fatty acids Neuroscience (1999) 94: 305- 314

McGahon BM, Martin DSD, Horrobin DF and Lynch MA Age-related changes in LTP and antioxidant defenses are reversed by an alpha-lipoic and acid-enriched diet Neurobiol. Aging (1999) 20: 655- 664

McGaugh JL and Roozendaal B Role of adrenal stress hormones in forming lasting memories in the brain Curr Opin Neurobiol. (2002) 12: 205-210

McKenna NJ, Lanz RB and O'Malley BW Nuclear receptor coregulators: cellular and molecular biology Endocrine Rev. (1999) 20: 321-344

McKenna NJ, and O'Malley BW Combinatorial control of gene expression by nuclear receptors and coregulators Cell (2002) 22: 465-474 
McNaughton BL, Barnes CA, Rao G, Baldwin J and Rassmussen M Long-term enhancement of hippocampal synaptic transmission and the acquisition of spatial information J. Neurosci. (1986) 6 : 563- 571

Meaney MJ, Mitchell JB and Aitken DH The effects of neonatal handling on the development of the adrenocortical response to stress: implications for neuropathology and cognitive deficits in later life Psychoneuroendocrinology (1991) 16: 85- 113

Mehta MR, Barnes CA and McNaughton BL Experience-dependent, asymmetric explanation of hippocampal place fields Proc. Natl. Acad. Sci. USA (1997) 8918-8921

Merrill DA, Roberts JA and Tuszynski MH Conservation of neuron number and size in entorhinal cortex layers II, III, and V/VI of aged primates J Comp Neurol. (2000) 422: 396- 401

Mizoguchi K, Yuzurihara M and Ishige A Chronic stress induces impairment of spatial working memory because of prefrontal dopaminergic dysfunction J Neurosci. (2000) 20: 1568- 1574

Moghaddam B Stress activation of glutamate neurotransmission in the prefrontal cortex: implication for dopamine-associated psychiatric disorder Biol. Psychatry (2002) 51: 775-787

Moore CI, Browning MD and Rose GM Hippocampal plasticity induced by primed burst, but not longterm potentiation, stimulation is impaired in area CA1 of aged Fischer 344 rats Hippocampus (1993) 3: $57-66$

Mordacq JC and Linzer DI Co-localization of elements required for phorbol ester stimulation and glucocorticoid repression of proliferin gene expression Genes Dev. (1989) 6: 760- 769

Morgan SL and Teyler TJ Epileptic-like activity induces multiple forms of plasticity in hippocampal area CA1 Brain Res. (2001) 917: 90- 96

Morgan SL and Teyler TJ Electrical stimuli patterned after the theta-rhythm induce multiple forms of LTP J. Neurophysiol. (2001) 86: 1289- 1296

Morre $\mathrm{C}$, Hugues $\mathrm{J}$ and Lazdunski $\mathrm{M}$ Quantitative autoradiographic mapping in rat brain of the receptor of apamin, a polypeptide toxin specific for one class of $\mathrm{Ca} 2+-d e p e n d e n t ~ \mathrm{~K}+$ channels Brain Res. (1986) 382: 239- 249

Morre C, Schimid-Antomarchi M, Hugues J and Lazdunski M Autoradiographic localization of apaminsensitive Ca-2+ dependent K+ channels in rat brain Eur. J Pharmacol. (1984) 100: 135- 136

Morris RG, Garrud P, Rawlin JN and Okeef J Place navigation impaired in rats with hippocampal lesions Nature (1982) 297: 681- 683

Moser EI, Krobert KA, Moser MB and Morris RGM Impaired spatial learning after saturation of longterm potentiation Science (1998) 281: 2038- 2042

Nakamura T, Barbara JG, Nakamura K and Ross WN Synergistic release of Ca2+ from IP3-sensitive stores evoked by synaptic activation of mGluRs paired with back-propagating action potentials Neuron (1999) 24: 727- 737

Nicoll RA The coupling of neurotransmitter receptors to ion channels in the brain Science (1988) 241: 545- 551

Nicolle MM, Gallagher M and McKinney M No loss of synaptic protein in the hippocampus in aged, behaviorally impaired rats Neurobiol. Aging (1999) 20: 343- 348 
Nissen RM and Yamamoto KR The glucocorticoid receptor inhibits NFkappaB by interfering with serine-2 phosphorylation of the RNA polymerase II carboxy-terminal domain Genes Dev. (2000) 14: 2314- 2329

Nohmi M, Shinnick-Gallagher P, Gean PW, Gallagher JP and Cooper CW Calcitonin and calcitonin gene-related peptide enhance calcium-dependent potentials Brain Res. (1986) 367: 346- 350

Norris CM, Halpain S, and Foster TC Alterations in the balance of protein kinase/phosphatase activities parallel reduced synaptic strength during aging J. Neurophysiol. (1998) 80: 1567- 1570

Norris CM, Korol DL and Foster TC Increased susceptibility to induction of long-term depression and long-term potentiation reversal during aging J Neurosci. (1996) 16: 5382- 5392

O'Brien JT, Ames D, Schweitzer I Colman P, Desmond P and Tress B. Clinical and magnetic resonance imaging correlates of hypothalamic-pituitary-adrenal axis function in depression and Alzheimer's disease Br J Psychiatry. (1996) 168: 679- 687

Oitzl MS, Reichardt HM, Joels M and de Kloet ER Point mutation in the mouse glucocorticoid receptor preventing DNA binding impairs spatial memory Proc. Natl. Acad. Sci. USA (2001) 98: 12790-12795

Ouanounou A, Zhang L, Charlton MP and Chalen PL Differential modulation of synaptic transmission by calcium chelators in young and aged hippocampal CA1 neurons: evidence for altered calcium homeostasis in aging J. Neurosci. (1999) 19: 906- 915

Pavlides C, Ogawa S, Kimura A and McEwen BS Role of adrenal steroid mineralocorticoid and glucocorticoid receptors in long-term potentiation in the CA1 field of hippocampal slices Brain Res. (1996) 738:229-235

Park CR, Campbell AM and Diamond DM Chronic psychosocial stress impairs learning and memory and increases sensitivity to yohimbine in adult rats Biol. Psychiatry (2001) 50: 994-1004

Park YB Ion selectivity and gating of small conductance Ca2+-activated $\mathrm{K}+$ channels in cultured rat adrenal chromaffin cells J Physiol. (1994) 481: 555- 570

Pedarzani P and Storm JF PKA mediates the effects of monoamine transmitters on the K+ current underlying the slow spike frequency adaptation in hippocampal neurons Neuron (1993) 11: 10231035

Pedarzani P and Storm JF Dopamine modulates the slow Ca(2+)-activated K+ current IAHP via cyclic AMP-dependent protein kinase in hippocampal neurons J. Neurophysiol. (1995) 74: 2749- 2753

Pedarzani $\mathrm{P}$ and Storm JF Evidence that $\mathrm{Ca} / \mathrm{Calmodulin}-$ dependent protein kinase mediates the modulation of the $\mathrm{Ca} 2+$ - dependent $\mathrm{K}+$ current, IAHP, by acetylcholine, but not by glutamates, in hippocampal neurons Pflugers Arch. (1996) 431: 723- 728

Peters A, Rosene DL, Moss MB, Kemper TL, Abraham CR, Tigges J and Albert MS Neurobiological bases of age-related cognitive decline in the rhesus monkey J. Neuropathol. Exp. Neurol. (1996) 55: 861- 874

Plotsky PM, Owens MJ and Nemeroff CB Psychoneuroendocrinology of depression. Hzpothalamicpituitary-adrenal axis Psychiatr Clin North Am. (1998) 21: 293- 307

Potier B, Poindessous-Jazat F, Dutar $\mathrm{P}$ and Billard JM NMDA receptor activation in the aged rat hippocampus Exp. Gerontol. (2000) 35: 1185- 1199 
Power JM, Oh MM and Diesterhoft JF Age related enhancement of the sIAHP in CA1 pyramidal neurons in vitro Soc. Neurosci. Abstr. (1999) 24, 84

Power JM, Wu WW, Sametsky E, Oh MM and Disterhoft JF Age-related enhancement of the slow outward calcium-activated potassium current in hippocampal CA1 pyramidal neurons in vitro J Neurosci. (2002) 22: 7234- 7243

Prasad AV, Pilcher WH and Joseph SA Nuclear factor-kappaB in rat brain: enhanced DNA-binding activity following convulsant-induced seizures Neurosci Lett. (1994) 170: 145- 148

Psarropoulou $C$ and Kostopoulos $G$ Long-term enhancement of postsynaptic excitability after brief exposure to Mg2(+)-free medium in normal and epileptic mice Brain Res. (1990) 508: 70 - 75

Quirk MC, Blum KI and Wilson MA Experience-dependent changes in extracellular spike amplitude may reflect regulation of dendritic action potential back-propagation in rat hippocampal pyramidal cells. J Neurosci. (2001) 21:240-248

Ray A and Sehgal PB Cytokines and their receptors: molecular mechanism of interleukin-6 gene repression by glucocorticoids J Am Soc Nephrol. (1992) S214- 221

Rao G, Barnes CA, McNaughton BL and Shen J Age-related decrease in the NMDA-mediated EPSP in FD Sco. Neurosci. Abst. (1994) 20, 1207

Rapp PR and Gallagher M Preserved neuron number in the hippocampus of aged rats with spatial learning deficits Proc. Natl. Acad. Sci. USA (1996) 93: 9926- 9930

Rassmussen T, Schliemann T, Sorensen JC, Zimmer J and West MJ Memory impaired aged rats: no loss of principal hippocampal and subicular neurons Neurobiol. Aging (1996) 17: 143- 147

Reincke M, Beuschlein F, Menig G, Hofmockel G, Arlt W, Lehmann R, Karl M and Allolio B Localization and expression of adrenocorticotropic hormone receptor mRNA in normal and neoplastic human adrenal cortex J Endocrinol. (1998) 156: 415- 423

Rodriguez R, Carson MA, Weigel NL, O'Malley BW and Schrader WT Hormone-induced changes in the in vitro DNA-binding activity of the chicken progesterone receptor Mol Endocrinol. (1989) 3: 356- 362

Rosenzweig ES, Rao G, McNaughton BL and Barnes CA Role of temporal summation in age-related LTP-induction deficits Hippocampus 1997

Rosenzweig ES and Barnes CA Impact of aging on hippocampal function: plasticity, network dynamics, and codnition Prog. Neurobiol. (2003) 69: 143- 179

Rusconi $\mathrm{S}$ and Yamamoto KR Functional dissection of the hormone and DNA binding activities of the glucocorticoid receptor EMBO Journal (1987) 5: 1309- 1315.

Sah P Ca2+-activated $\mathrm{K}+$ currents in neurons: Types, physiological roles and modulation Trends Neurosci. (1996) 4: 150-154

Sah P and Bekkers JM Apical dendritic location of slow afterhyperpolarization current on hippocampal pyramidal neurons: implications for the integration of long-term potentiation $J$ Neurosci. (1996) 16: 4537- 4542

Sailer CA, Hu H, Kaufmann WA, Trieb M, Schwarzer C, Storm JF and Knaus HG Regional differences in distribution and functional expression of small-conductance Ca2+-activated $\mathrm{K}+$ channels in rat brain J Neurosci. (2002) 22: 9698- 9707 
Salminen A, Liu PK and Hsu CY Alteration of transcription factor binding activities in the ischemic rat brain Biochem Biophys Res Commun. (1995) 212: 939- 944

Sanchez ER, Toft DO, Schlesinger MJ and Pratt WB Evidence that the 90-kDa phosphoprotein associated with the untransformed $\mathrm{L}$-cell glucocorticoid receptor is a murine heat shock protein $\mathrm{J}$ Biol Chem (1985) 260: 12398- 12401.

Sandi C, Loscertales M and Guaza C Experience-dependent facilitating effect of corticosterone on spatial memory formation in the water maze Eur J Neurosci. (1997) 9: 637-642

Schafe GE, Nader K, Blair HT and LeDoux JE Memory consolidation of Pavlovian fear conditioning: a cellular and molecular perspective Trends Neurosci. (2001) 24: 540-546

Schauer M, Chalepakis G, Willmann T and Beato M Binding of hormone accelerates the kinetics of glucocorticoid and progesterone receptor binding to DNA Proc. Natl. Acad. Sci. USA (1989) 86: 11231127

Scheinman RI, Cogswell PC, Lofquist AK and Baldwin AS Jr. Role of transcriptional activation of I kappa B alpha in mediation of immunosuppression by glucocorticoids Science. (1995) 270: 283- 286

Schuh S, Yonemoto W, Brugge J, Bauer VJ, Riehl RM, Sullivan WP and Toft DO A 90,000-dalton binding protein common to both steroid receptors and the Rous sarcoma virus transforming protein, pp60v-src J Biol Chem (1985) 260: 14292-14296

Schumacher MA, Rivard AF, Bachinger HP and Adelman JP Structure of the gating domain of a Ca2+activated K+ channel complexed with Ca2+/calmodulin Nature (2001) 410: 1120- 1124

Schumacher M, Weill-Engerer S, Liere P, Robert F, Franklin RJ, Garcia-Segura LM, Lambert JJ, Mayo W, Melcangi RC, Parducz A, Suter U, Carelli C, Baulieu EE and Akwa Y Steroid hormones and neurosteroids in normal and pathological aging of the nervous system Prog Neurobiol. (2003) 71: 3-29

Schweitzer P, Madamba S and Siggins GR Arachidonic acid metabolites as mediators of somatostatin induced increase of neuronal M-current Nature (1990) 346: 464- 467

Seeman TE, McEwen BS, Singer BH, Albert MS and Rowe JW Increase in urinary cortisol excretion and memory declines: MacArthur studies of successful aging J Clin Endocrinol Metab. (1997) 82: 2458- 2465

Seeman TE and Robbins RJ Ageing and hypothalamic-pituitary-adrenal response to challenge in humans Endocrine Rev. (1994) 15: 233- 260

Sen R and Baltimore D Inducibility of kappa immunoglobulin enhancer-binding protein Nf-kappa B by a posttranslational mechanism Cell (1986) 47: 921- 928

Shankar S, Teyler TJ and Robbins $\mathrm{N}$ Aging differently alters forms of long-term potentiation in rat hippocampal area CA1 J. Neurophysiol. (1998) 79: 334- 341

Shapiro ML, Tanila $\mathrm{H}$ and Eichenbaum $\mathrm{H}$ Cues that hippocampal place cells encode: dynamic and hierarchial representation of local and distal stimuli Hippocamps (1997) 7: 624-642

Shi SH, Hayashi Y, Petralia RS, Zaman SH, Wenthold RJ, Svoboda K and Malinow R Rapid spine delivery and redistribution of AMPA receptors after synaptic NMDA receptor activation Science (1999) 284: 1811- 1816

Shors TJ, Chua C and Falduto J Sex differences and opposite effects of stress on dendritic spine density in the male versus female hippocampus J Neurosci. (2001) 21: 6292-6297 
Shors TJ, Lewczyk C, Pacynski M, Mathew PR and Pickett J Stages of estrous mediate the stressinduced impairment of associative learning in the female rat Neuroreport (1998) 9: 419-423

Schowalter DB, Sullivan WP, Maihle NJ, Dobson AD, Conneely OM, O'Malley BW and Toft DO Characterization of progesterone receptor binding to the 90- and 70-kDa heat shock proteins $\mathrm{J}$ Biol Chem. (1991) 266: 21165- 21173

Silvestrini G, Mocetti P, Di Grezia R, Berni S and Bonucci E Localization of the glucocorticoid receptor mRNA in cartilage and bone cells of the rat. An in situ hybridization study Eur J Histochem. (2003) 47: $245-252$

Slater EP, Rabenau O, Karin M, Baxter JD and Beato M Glucocorticoid receptor binding and activation of a heterologous promoter by dexamethasone by the first intron of the human growth hormone gene Mol Cell Biol (1985) 11: 2984- 2992

Smith TD, Adams MM, Gallagher M, Morrison JH and Rapp PR Circiut- specific alterations in hippocampal synaptophysin immunoreactivity predict spatial learning impairment in aged rats $\mathrm{J}$. Neurosci. (2000) 20: 6587- 6593

Solomon PR and Pendelbury WW A model systems approach to the study of disorders of learning and memory Neurobiol. Aging (1994) 15: 283- 286

Solomon PR, Vander Schaaf ER, Thompson RF and Weisz DJ Hippocampus and trace conditioning of the rabbits classically conditioned nictitating membrane response Behav. Neurosci. (1986) 5: 729- 744

Southwick SM, Bremner JD, Rasmusson A, Morgan CA 3rd, Arnsten A and Charney DS Role of norepinephrine in the pathophysiology and treatment of posttraumatic stress disorder Biol Psychiatry (1999) 46: 1192- 1204

Squire LR Memory and the hippocampus: a synthesis from finding with rats, monkeys, and humans Psychol Rev. (1992) 99: 195-231

Squire LR and Zola-Morgan S The medial temporal lobe memory system Science (1991) 253:1380-1386

Starkman MN, Schteingart DE and Schork MA Depressed mood and other psychiatric manifestations of Cushing's syndrome: relationship to hormone levels Psychosom Med (1981) 43: 3- 18

Starkman MN, Schteingart DE, and Shork MA Cushing's syndrome after treatment: changes in cortisol and ACTH levels, and amelioration of the depressive syndrome Psychiatry Res. (1986) 19: 177- 188

Stocker $\mathrm{M}$ and Pedarzani $\mathrm{P}$ Differential distribution of three Ca2+-activated K+ channel subunits, SK1, SK2, and SK3, in the adult rat central nervous system Mol Cell Neurosci. (2000) 15: 476- 493

Storm JF Potassium current in hyppocampal pyramidal cells Prog Brain Res. (1990) 83: 161- 187

Strack S, Barban MA, Wadzinski BE and Colbran RJ Differential inactivation of postsynaptic densityassociated soluble CA2+/calmodulin-dependent protein kinase II by protein phosphatases 1 and $2 \mathrm{~A}$ J. Neurochem. (1997) 68: 2119- 2128

Straube KT, Deyo RA, Moyer JR Jr. and Disterhoft JF Dietary nimodipme improves associative learning in aging rabbits Neurobiol. Aging (1990) 11: 659- 661

Sweatt JD Mechanisms of memory Elsevier Academic Press (2003) 
Tamatani M, Che YH, Matsuzaki H, Ogawa S, Okado H, Miyake S, Mizuno T and Tohyama M Tumor necrosis factor induces Bcl-2 and Bcl-x expression through NFkappaB activation in primary hippocampal neurons J Biol Chem. (1999) 274: 8531- 8538

Tanila H, Shapiro ML and Eichenbaum H Discordance of spatial representation in ensembles of hippocampal place cells Hippocamps (1997) 7: 613-623

Thibault $\mathrm{O}$ and Landfield PW Increase in single L- type calcium channels in hippocampal neurons during aging Science (1996) 272: 1017- 1020

Toescu EC and Verkhratsky A Parameters of calcium homeostasis in normal neuronal ageing $\mathrm{J}$ Anat. (2000) 197 563- 569

Toescu EC and Verkhratsky A Neuronal ageing in long-term cultures: alterations of Ca2+ homeostasis Neuroreport (2000) 11: 3725- 3729

Tonegawa S, Tsien JZ, McHugh TJ, Hueta P, Blum KI and Wilson MA Hippocampal CA1-regionrestricted knockout of NMDAR1 gene distrupts synaptic plasticity, place fields, and spatial learning Cold Spring Harb. Symp. Quant. Biol. (1996) 61: 225- 238

Torres GE, Arffcen CL and Andrade R 5- Hydroxytryptamine 4 receptors reduce afterhyperpolarization in hippocampus by inhibiting calcium-induced calcium release Mol. Pharmacol. (1995) 50: 1316- 1322

Tsai MJ and O'Malley BW, Mechanisms of regulation of gene transcription by steroid receptors, The hormonal control of gene transcription, Molecular aspects of cellular regulation (1991) Vol.6 Chapter 5

Tsai SY, Tsai MJ and O'Malley BW Cooperative binding of steroid hormone receptors contributes to transcriptional synergism at target enhancer elements Cell (1989) 57: 443- 448

Tsien JZ, Hueta PT and Tonegawa $S$ The essential role of hippocampal CA1 NMDA receptor dependent synaptic plasticity in spatial memory Cell (1996) 87: 1327- 1338

Van Cauter E, Leproult R and Kupfer DJ Effects of gender and age on the levels and circadian rhythmicity of plasma cortisol Clin Endocrinol Metab. (1996) 81: 2468- 2473

Verma IM, Stevenson JK, Schwarz EM, Van Antwerp D and Miyamoto S Rel/NF-kappa B/I kappa B family: intimate tales of association and dissociation Genes Dev. (1995) 9: 2723- 2735

von Bohlen und Halbach $\mathrm{O}$ and Unsicker $\mathrm{K}$ Morphological alterations in the amygdala and hippocampus of mice during ageing Eur J Neurosci. (2002) 16: 2434- 2440

Wellman CL Dendritic reorganization in pyramidal neurons in medial prefrontal cortex after chronic corticosterone administration J Neurobiol. (2001) 49: 245-253

Wenk GL and Barnes CA Regional changes in the hippocampal density of AMPA and NMDA receptors across the lifespan of the rat Brain Res. (2000) 885: 1- 5

West MJ New stereological methods for counting neurons Neurobiol. Aging (1993) 14: 275- 285

West MJ Regionally specific loss of neurons in the aging human hippocampus Neurobiol. Aging (1993) 17: 287- 293

West MJ, Amaral DJ and Rapp PR, Preserved hippocampal cell number in aged monkeys with recodnitioin memory deficits Soc. Neurosci. Abstr. (1993) 19: 599 
Winson J Loss of hippocampal theta rhythm results in spatial memory deficit in the rat Science (1978) 201:160-160

Wolf OT HPA axis and memory Best Pract Res Clin Endocrinol Metab. (2003) 17 (2): 287-299

Wolf OT, Convit A, and de Leon MJ Basal hypothalamic-pituitary-adrenal axis activity and corticotropin feedback in young and older men: relationship to magnetic resonance imaging derived hippocampus and cingulate gyrus volumes Neuroendocrinology (2002) 75: 241- 249

Wolf OT, Convit A, McHugh PF, Kandil E, Thorn EL, De Santi S, McEwen BS and de Leon MJ Cortisol differently affects memory in young and elderly men. Behav Neurosci. (2001) 105: 1002-1011

Wolf OT, Schommer NC, Hellhammer DH, McEwen BS and Kirschbaum C The relationship between stress induced cortisol levels and memory differs between men and women Psychoneuroendocrinology (2001) 26: 711-720

Wolkowitz OM, Reus VI, Canick J, Levin B and Lupien S Glucocorticoid medication, memory and steroid psychosis in medical illness Ann N Y Acad Sci. (1997) 823: 81- 96

Wong GH, Elwell JH, Oberley LW and Goeddel DV Manganous superoxide dismutase is essential for cellular resistance to cytotoxicity of tumor necrosis factor Cell (1989) 58: 923- 931

Wood GE, Beylin AV and Shors TJ The contribution of adrenal and reproductive hormones to the opposing effects of stress on trace conditioning in males versus females Behav Neurosci. (2001) 115: 175- 187

Wood GE and Shors TJ Stress facilitates classical conditioning in males, but impairs classical conditioning in females through activational effects of ovarian hormones Proc Natl Acad Sci U S A. (1998) 95: 4066- 4071

Yehuda $R$ Linking the neuroendocrinology of post-traumatic stress disorder with recent neuroanatomic findings Semin Clin Neuropsychiatry. Semin Clin Neuropsychiatry (1999) 4: 256- 265

Zhang $\mathrm{L}$ and McBain $\mathrm{CJ}$ Potassium conductances underlying repolarization and afterhyperpolarization in rat CA1 hippocampal interneurons J Physol. (1995) 488: 661-672

Zhang Z, Jones S, Hagood JS, Fuentes NL and Fuller GM STAT3 acts as a co-activator of glucocorticoid receptor signaling J Biol Chem. (1997) 272: 30607- 30610 


\section{Chapter 2}

\section{Transcriptional Regulation of the Mouse Gene for the Calcium-Activated Potassium Channel SK2 in PC12 Cells}

\section{Introduction}

There is evolving recognition that stress modulates hippocampal long-term potentiation (LTP) as well as learning and memory (Kim and Diamond, 2002). Thus far, little is known about the underlying genomic processes. In response to stress, corticosteroids, which are released from the adrenal gland, enter the brain after crossing the blood-brain barrier (McEwen et al., 1986; De Kloet 1991). Corticosteroids can increase or decrease the transcription of specific target genes via binding to two different corticosteroid-binding receptors: the glucocorticoid receptor (GR) and the mineralocorticoid receptor $(\mathrm{MR})$, the latter showing a 10-fold higher affinity for corticosterone than the former (De Kloet et al., 1993; van Steensel et al., 1996). Corticosteroids affect the signaling properties of hippocampal neurons and modulate the amplitude of afterhyperpolarizations (AHPs) via genomic action (Joels et al., 1991; Karst et al., 1991, 1994; Joels et al., 2003). We were now interested in identifying novel target genes for these corticosteroid effects, particularly those that might be involved in controlling neuronal activity.

In most central neurons, small conductance $\mathrm{Ca}^{2+}$-activated potassium (SK) channels contribute to AHPs, which control neuronal signaling. Immunohistochemistry revealed a close correlation between apamin-sensitive currents, which underlie medium AHPs, and the distribution of homotetrameric, apamin-sensitive SK2 channels in the rat brain (Sailer et al., 2002; Villalobos et al., 2004). The mAHP that follows action potentials is an important intrinsic negative feedback mechanism determining the firing 
rate (Stocker et al., 1999; Stackman et al., 2002). When apamin blocks SK channels and thereby reduces underlying mAHPs the number of action potentials discharged in response to current injection is increased in CA1 neurons. In parallel, apamin block of SK channel activity enhances synaptic plasticity induced by high-frequency stimulation and accelerates hippocampal-dependent spatial memory encoding (Stackman et al., 2002). Thus, the modulation of SK2 channels is of fundamental importance to synaptic plasticity and cognitive performance. Initial characterization identified putative binding sites for corticosteroid receptors and for the transcription factor nuclear factor-kappaB (NFkappaB) on the upstream regulatory part of the murine SK2 gene, which might be important for the control of SK2 gene expression. NF-kappaB is ubiquitously expressed in an inactive form in the cytosol by interaction with inhibitory proteins (IkappaB). The phosphorylation and subsequent degradation of these proteins results in translocation of the liberated NF-kappaB to the nucleus where it induces transcription of target genes (Baldwin, 1996). Considering that acute stress not only activates corticosteroid receptors but also induces the translocation of NF-kappaB to the nucleus (Madrigal et al., 2001) the present study was designed to investigate, by use of molecular and in vitro pharmacological functional studies, whether corticosteroids and NF-kappaB can modulate the expression of SK2 in PC12 cells.

\section{Materials and methods}

\section{Cloning of SK2 reporter vectors}

Fragments of murine SK2 promoter were cloned from genomic DNA using PCR. Primers were designed according to published sequences (GenBank accession no AC121957). The primer sequences used in this study were SK2-G5, 5'gcattagcagatattgggtggat-3' and SK2-G8, 5' - agccgatgttctggttcttctttt-3'. 3.6 Kb DNA fragment was amplified with C57BL/6J mouse genomic DNA and pfu DNA polymerase (Stratagene, CA, USA). The amplified DNA fragment was sub-cloned into a TOPO ZeroBlunt cloning vector (Invitrogen, CA, USA) following manufacturer's instruction and transformed into JM109. It contained 3133bp of the 5' upstream part from the translation start codon and 567bp of translated region. To obtain the construct pGLF, the subcloned 
SK2-TOPO vector was cut with HindIII and the DNA fragment that contained the 5' flanking region of SK2 was purified and cloned into the luciferase expression vector pGL3 (Promega, WI, USA). pGLG was generated by cutting pGLF with SmaI, which removed 1428 base pairs from the 5' upstream part, self-ligased and transformed into JM109. When pGLG was cut with PstI, self-ligased and transformed into JM109 we obtained pGLH. To construct pGL-MG, pGLG was opened at the SmaI site and ligated with the $1.4 \mathrm{~Kb}$ SmaI DNA fragment from pGLF. We isolated $2.2 \mathrm{~Kb}$ AccI DNA fragments from pGLF, which contained a putative NF-kappaB binding site and transferred it to a pDrive cloning vector (Qiagen). This fragment was transferred to the pGL3 luciferase vectors using MluI and HindIII sites. All sequences of reporter vectors were confirmed by sequencing.

\section{Cell culture}

A PC12 cell line was maintained in RPMI1640 medium (GIBCO, CA, USA) supplemented with $10 \%$ heat-inactivated fetal calf serum, $100 \mu \mathrm{g} / \mathrm{ml}$ penicillin and 100 $\mathrm{U} / \mathrm{ml}$ streptomycin at $37^{\circ} \mathrm{C}$ in a humidified atmosphere $5 \% \mathrm{CO}_{2}$ and $95 \%$ room air. Cells were divided every 5 to 6 days.

\section{Transient transfection, antisense and drugs treatments to PC12 cells}

$10 \times 10^{6}$ cells were grown in 24 well plates in a total volume of $500 \mu 1$. They were transiently transfected with $1.6 \mu \mathrm{g}$ of an SK2/luciferase construct and $0.4 \mu \mathrm{g}$ of a cotransfection control plasmid, pCMV SPORT B-gal (Invitrogen, CA, USA) using $5 \mu \mathrm{g}$ of Lipofectamine 2000 (Invitrogen, CA, USA) under antibiotics deprived condition. Two $\mu \mathrm{g}$ DNA and $5 \mu \mathrm{g}$ of Lipofectamine 2000 were diluted in $50 \mu 1$ Optimem (GIBCO, CA, USA). After 20 minutes incubation at room temperature the DNA/Lipofetamine complex was directly added to the cells. All transfection procedures were performed according to the manufacturer's instruction.

Cells were treated with spironolactone and mifepristone (MR and GR antagonists, respectively) 44 hours after transfection. At 45 hours after transfection, cells were treated with corticosterone, aldosterone and dexamethasone (MR and GR agonists). All agonists 
and antagonists were dissolved in 75\% ethanol and diluted with culture medium 1: 50 . Final concentration of ethanol in culture was less than $0.1 \%$.

We applied SN50 (NF-kappaB peptide inhibitor) and a corresponding control peptide (Santa Cruz, CA, USA) after 47 hours of transfection with a final concentration of $50 \mu \mathrm{g} / \mathrm{ml}$. C2-ceramide (Sigma) activating NF-kappaB was dissolved in $75 \%$ ethanol and diluted with culture medium 1:50. It was treated 24 hours after transfection with a final concentration of $20 \mu \mathrm{M}$. The final concentration of ethanol was less than $0.1 \%$. Transfected cells were harvested 48 hours after transfection, washed with PBS and analyzed. Antisense probes targeting at NF-kappaB subunits p50, p65 and control oligonucleotides have been provided by Biognostik (Göttingen, Germany). The lyophilized oligonucleotides were dissolved in $1 \mathrm{x}$ Dilution buffer to a stock concentration of $2 \mathrm{nmol} / \mu \mathrm{l}$ and stored at $-20{ }^{\circ} \mathrm{C}$. They were applied 24 hours after transfection with a final concentration of $2 \mu \mathrm{M}$. All DNA constructs used for the transfection assay were prepared with ENDO free plasmid maxi prep kit (Qiagen).

\section{Reporter gene assays and protein assay}

Harvested cells were lysed with $300 \mu$ l luciferase cell culture lysis buffer (Promega, WI, USA) and a luciferase assay was performed with Luciferase Assay System (Promega) following manufacturer's instruction. Luciferase activity was measured with Wallac 1450 Microbeta Plus Liquid Scintillation Counter (PerkinElmer, USA). As control $ß$-galactosidase activity was determined by a $\beta$-galactosidase assay kit (Stratagene, CA, USA). All procedures were performed according to the manufacturer's protocol. The protein amount was calculated using a standard Bradford assay (Bio-Rad Laboratories, Inc., Muenchen, Germany).

\section{Statistics}

Statistical comparisons were made using Students `t-test or ANOVA. All RT-PCR experiments were repeated at least twice. Transfection assays was repeated at least 4 times per experiment. Data were expressed as mean \pm standard error (SEM). Asterisks indicate the statistical difference versus vehicle controls. The significance was determined at the level of $p<0.05$. 


\section{Results}

\section{Cloning of murine SK2 promoter fragments}

Fragments of murine SK2 promoter were cloned from genomic DNA using PCR. Primers were designed according to published sequences (GenBank accession no AC121957). Clones carrying the mouse SK2 gene were isolated, and an approximate 3.6kb 5'-flanking region was sequenced in this study.

$$
1 \mathrm{~Kb}
$$
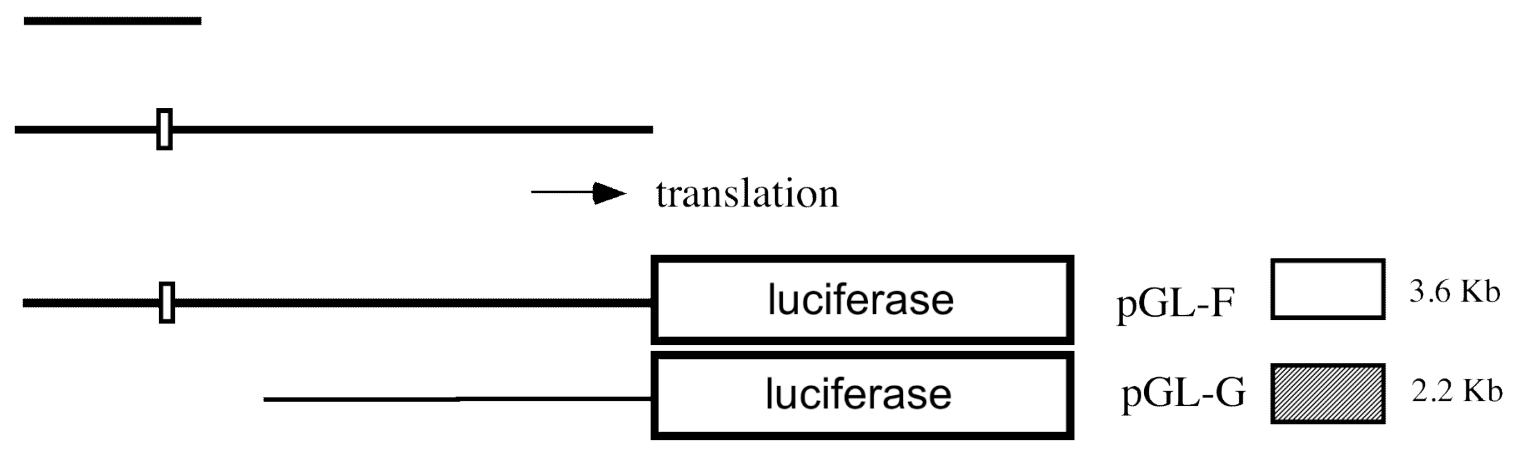

[ Putative MR/GR binding site

Fig.1 Regulatory region of murine SK2 gene has putative MR/GR binding sites. Two luc/SK2 reporter vectors were constructed. pGL-F containing a $3.6 \mathrm{~Kb} 5$ ' flanking part of the SK2 gene contains the putative binding site, which is missing in the pGL-G $(2.2 \mathrm{~Kb})$ construct.

\section{Corticosteroid regulation of the SK2 channel promoter}

The reporter construct pGL-F, which contains putative MR/GR binding elements, was transiently transfected into PC12 cells together with a control plasmid, pCMV SPORT B-gal, to control transfection efficiency. Forty-four hours after transfection, cells were treated with corticosteroid receptor agonists and antagonists. As shown in Fig. 2, A, corticosterone stimulated the pGL-F reporter at a concentration of $450 \mathrm{nM}$. No significant change in activation was observed when the corticosterone concentration was increased to $900 \mathrm{nM}$. The mineralocorticoid aldosterone (Fig. 2, C) and the glucocorticoid 
dexamethasone (Fig. 2, E) stimulated the same reporter in a similar concentrationdependent manner, which started from $28 \mathrm{nM}$ in the case of aldosterone and from 12.5 $\mathrm{nM}$ in the case of dexamethasone. The effects of aldosterone and dexamethasone on pGLF-Luc expression were attenuated by $240 \mathrm{nM}$ of the MR antagonist spironolactone (Fig. 2, C) and by $233 \mathrm{nM}$ of the GR antagonist mifepristone, respectively (Fig. 2, E). An additional construct, pGL-G, was generated by reduction of the promoter region from 3.6 $\mathrm{Kb}$ to $2.2 \mathrm{~Kb}$. Corticosterone (Fig. 1, B), aldosterone (Fig. 1, D) and dexamethasone (Fig. 1, F) had no stimulatory effect on the pGL-G reporter gene expression, suggesting the presence of potential glucocorticoid response element(s) (GRE) in the deleted region (Fig. 1). 
A

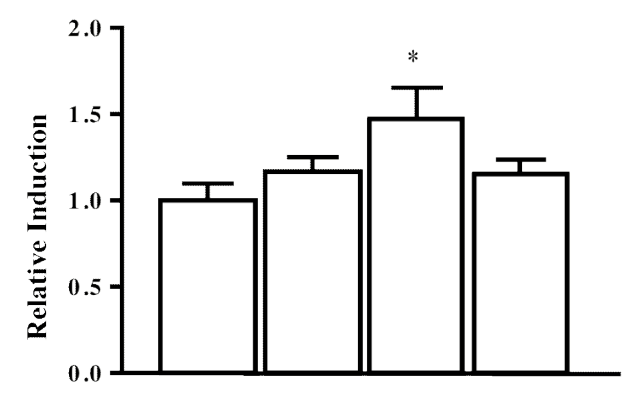

$\begin{array}{lllll}\text { Cort } & 0 & 29 & 435 & 870\end{array}$

(nM)

C

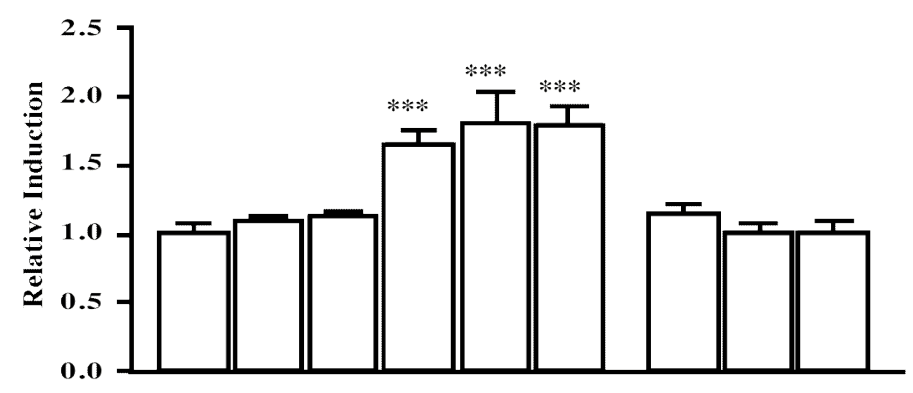

$\begin{array}{lccccccccc}\text { Ald (nM) } & 0 & 2.8 & 14 & 28 & 420 & 840 & 0 & 28 & 840 \\ \text { Spi (nM) } & 0 & 0 & 0 & 0 & 0 & 0 & 240 & 240 & 240\end{array}$

$\mathbf{E}$

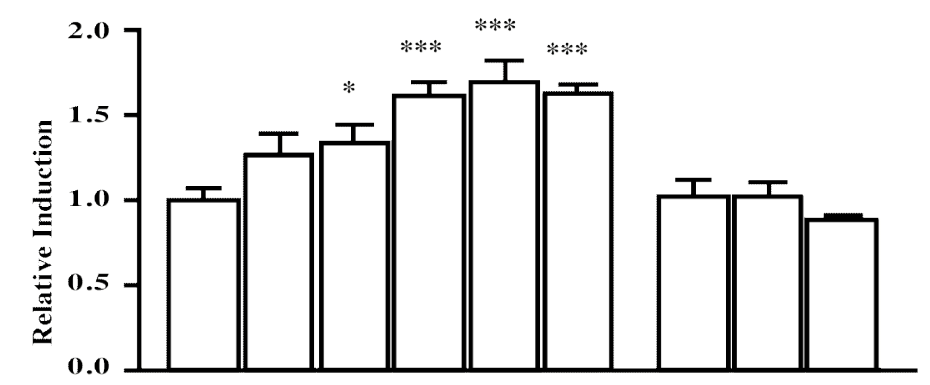

$\begin{array}{llllllllll}\operatorname{Dex}(\mathrm{nM}) & 0 & 2.5 & 12.5 & 25 & 375 & 750 & 0 & 25 & 750\end{array}$

$\begin{array}{llllllllll}\text { Mif }(n M) & 0 & 0 & 0 & 0 & 0 & 0 & 233 & 233 & 233\end{array}$
B

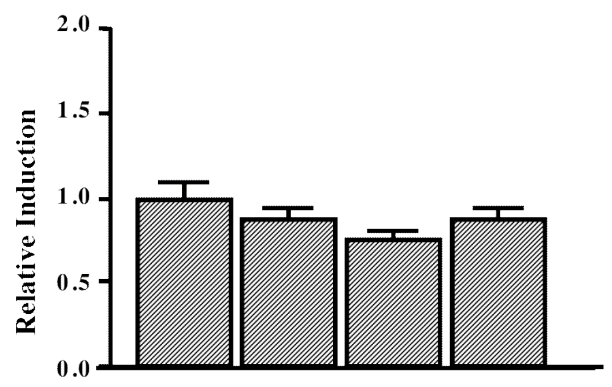

$\begin{array}{lllll}\text { Cort } & 0 & 29 & 435 & 870\end{array}$

D

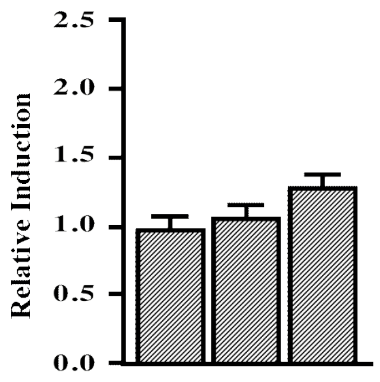

$\begin{array}{lll}0 & 28 & 840\end{array}$

$\begin{array}{lll}0 & 0 & 0\end{array}$

$\mathbf{F}$

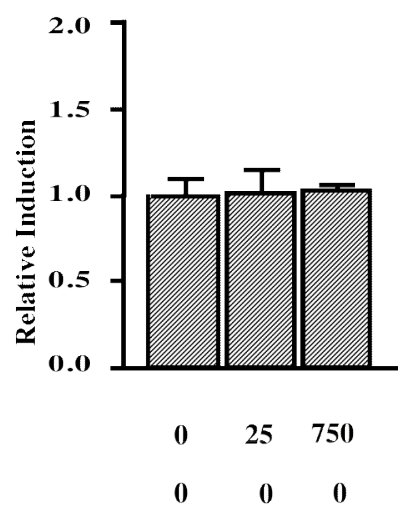

Fig. 2 Corticosteroids modulate promoter activity of the murine SK2 gene. Bar graphs show relative luciferase activity of SK2/luc vectors containing the 5' flanking region of the SK2 gene in PC12 cells. A; Application of corticosterone (435nM) increased pGL-F 
SK2/luc reporter vector expression. B; Application of corticosterone didn't have effect on pGL-G SK2/luc vector. C; Application of aldosterone induced pGL-F expression in doesdependent manner. This effect was blocked by application of spironolactone (240 nM ) $\mathrm{D}$; the expression of pGL-G vector wasn't changed. E; Application of dexamethasone increased pGL-F expression. Application of mifepristone $(233 \mathrm{nM})$ could block this effect. F; Application of dexamethasone couldn't modify expression of pGL-G. Luciferase activity was normalized to ß-galactosidase activity, which was co-transfected. Data are averages of 8 measurements from 4 different transfection experiments. Data were expressed as mean \pm standard error $(\mathrm{SEM}) * \mathrm{P}<0.05$, *** $\mathrm{P}<0.0001$ by ANOVA with Fisher's PLSD post hoc test.

\section{Activation of the SK2 channel Promoter by C2-ceramide}

Sequence analysis of the deleted $1.4 \mathrm{~Kb}$ promoter region also revealed a potential response element for NF-kappaB (Fig. 3, A). In the presence of NF-kappaB SN50 (50 $\mu \mathrm{g} / \mathrm{ml}$ ), which inhibits the translocation of NF-kappaB from the cytoplasm to the nucleus, expression of both reporter gene constructs was unchanged when compared to vehicletreatment (Fig. 3, B). Interestingly, activation of NF-kappaB by C2-ceramide $(20 \mu \mathrm{M})$ was clearly capable of inducing luciferase activity of the pGL-F promoter construct (Fig. $3, \mathrm{C})$. 


\section{A}

$1 \mathrm{~Kb}$

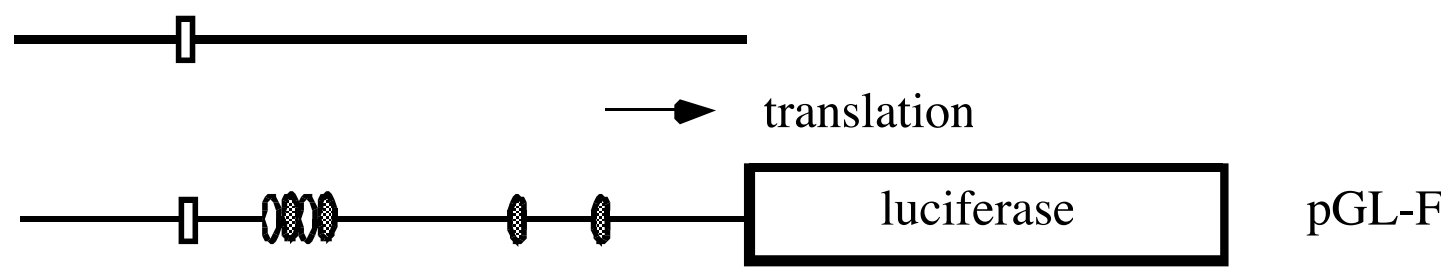

Putative MR/GR binding site

Putative NF-kappaB binding site

Putative SP binding site

B
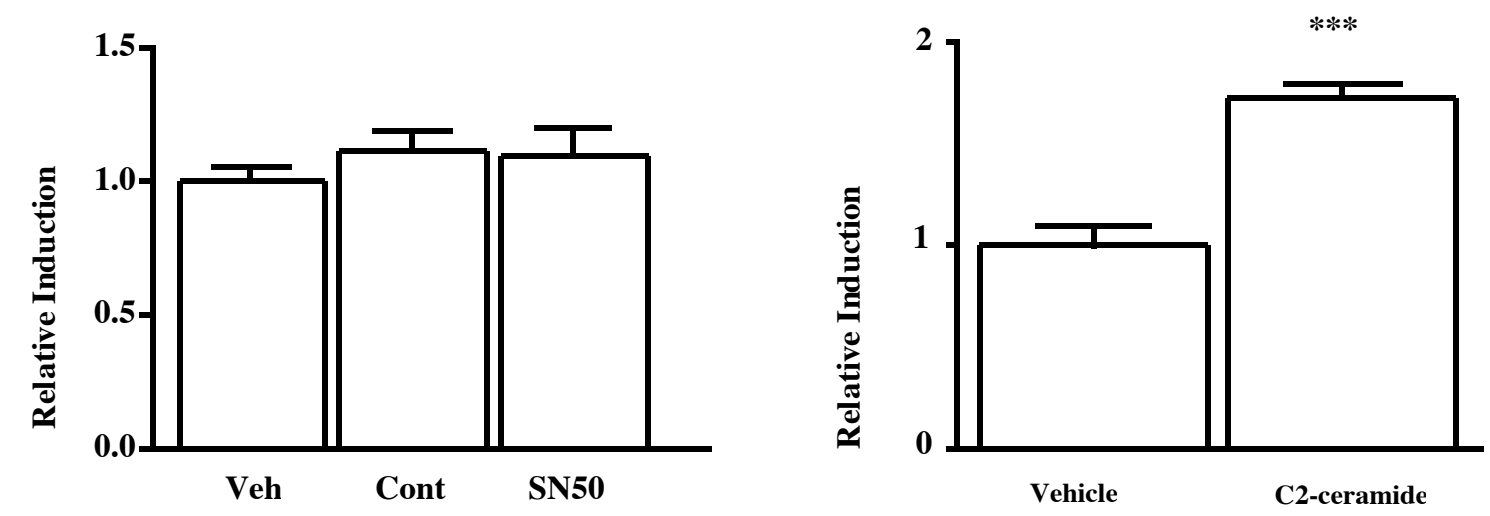

Fig.3 C2-ceramide increased SK2 transcription in PC12 cells. A; Map of pGL-F vector containing the 5' flanking region of the SK2 gene. There are two putative NF-kappaB binding sites and four putative SP binding sites. B; Application of the specific peptide inhibitor, SN50 $(50 \mu \mathrm{g} / \mathrm{ml})$ had no effect on the expression of SK2. C; Application of C2ceramide $(20 \mu \mathrm{M})$ increased the expression of SK2. Data were normalized using the amount of $B$-galactosidase. These data are averages of 8 measurements from 4 different transfection experiments. Data were expressed as mean \pm standard error (SEM) *** $\mathrm{P}<0.0001$ by ANOVA with Fisher's PLSD post hoc test. 


\section{Antisense probes against NF-kappaB subunits down regulated ceramide-induced}

\section{SK2 expression.}

We treated $2 \mu \mathrm{M}$ of antisense oligonucleotides against the NF-kappaB subunits p50 and p65. Semi-quantitative RT-PCR showed that PC12 cells endogenously express both subunits. Antisense probes against p50 and p65 successfully reduced the mRNA amount of both subunits (Fig.4, A, B and Fig.5, A, B). Antisense probe treatment down regulated ceramide-induced elevation of SK2 expression in PC12 cells (Fig.4, C and Fig.5, C). This suggested that C2-ceramide increased SK2 expression through NFkappaB.

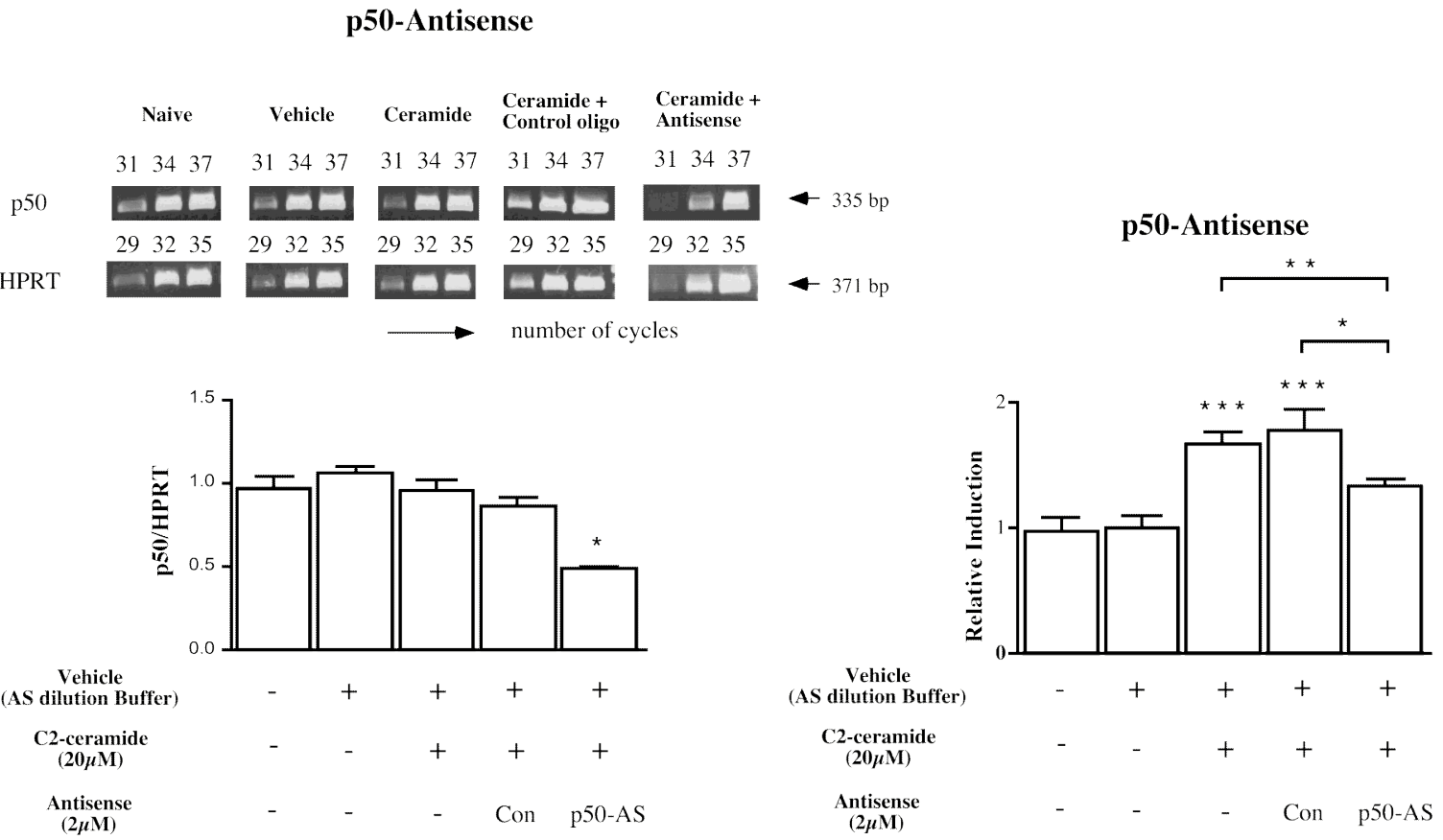

Fig.4 Antisense probes against NF-kappaB subunits p50 down regulated ceramideinduced increase in SK2 expression in PC12 cells. A; Semi-quantitative RT-PCR shows that antisense probes against NF-kappaB subunit p50 successfully reduced the mRNA level. HPRT was used as housekeeping control gene. B; Bar graphs show the relative amount of p50 transcripts normalized to the amount of HPRT transcripts. All experiments were repeated at least twice. C; Luciferase activity of the pGL-F reporter vector was reduced after antisense treatment. Luciferase activity was normalized to the amount of co-transfected B-galactosidase. All data are averages of 8 measurements from 4 different transfection experiments. Data were expressed as mean \pm standard error (SEM); ${ }^{*} \mathrm{p}<0.05$, $* * \mathrm{p}<0.005, * * * \mathrm{P}<0.0001$ by ANOVA with Fisher's PLSD post hoc test. 


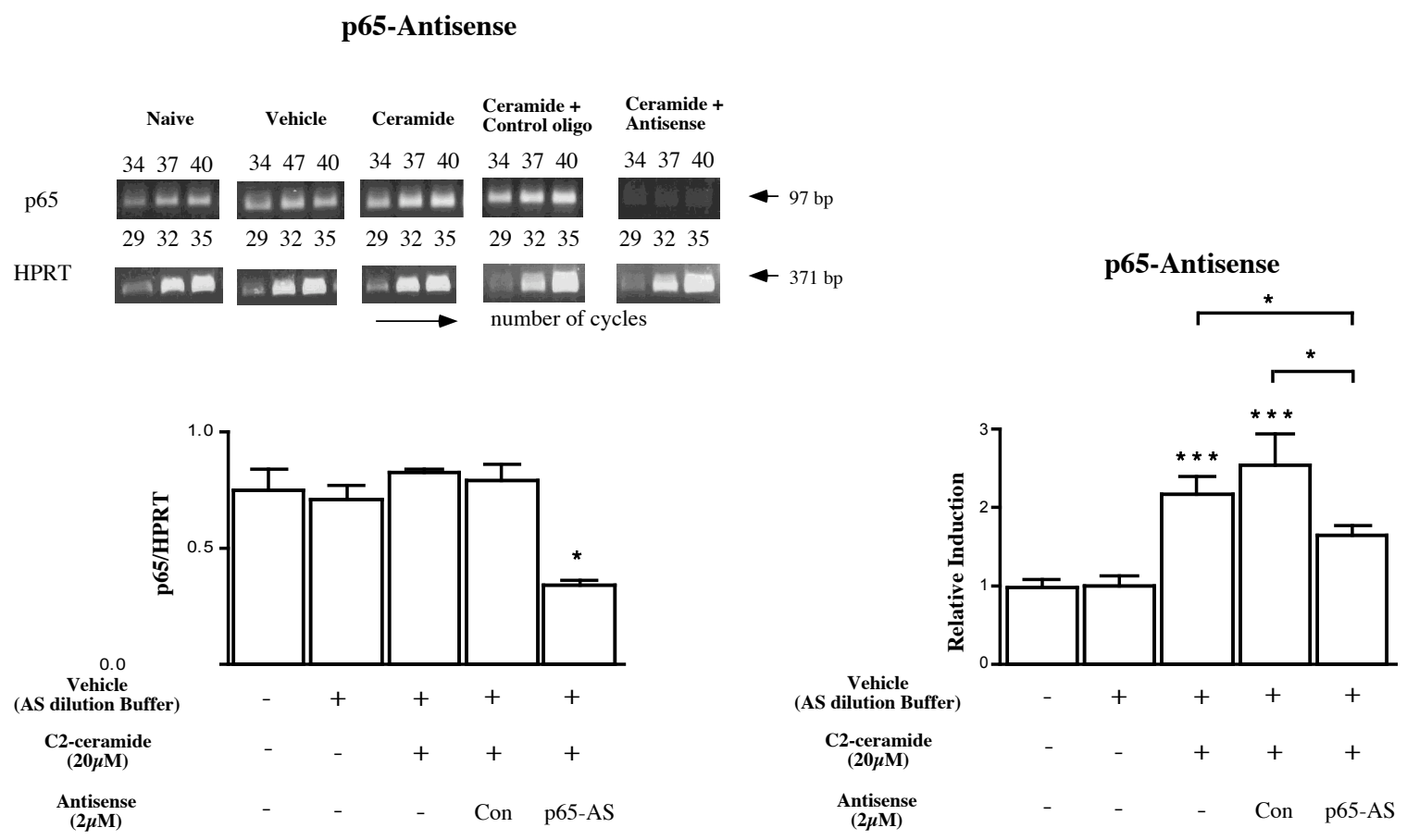

Fig.5 Antisense probes against the NF-kappaB subunit p65 downregulated ceramideinduced increase in SK2 expression in PC12 cells. A; Semi-quantitative RT-PCR showed that antisense probes against p65 successfully reduced the amount of p65 transcripts. HPRT was used as housekeeping gene. B; Bar graphs show the relative amount of p65 transcripts normalized to the amount of HPRT transcripts. All experiments were repeated at least twice. C; Luciferase activity of the pGL-F reporter vector was reduced after antisense treatment. Luciferase activity was normalized to co-transfected betagalactosidase. All data are averages of at least 8 measurements from 4 different transfection experiments. Data were expressed as mean \pm standard error $(\mathrm{SEM}) ;{ }^{*} \mathrm{p}<0.05$, *** $\mathrm{P}<0.0001$ by ANOVA with Fisher's PLSD post hoc test.

\section{Regulation of SK2 promoter activity by two putative NF-kappaB binding motifs}

As shown in figure 3, A, the $3.6 \mathrm{~Kb} 5$ ' flanking region of the SK2 gene has two putative NF-kappaB binding sites. I constructed several SK2/luc vectors to investigate the role of these binding sites for transcription (Fig.6, A). Interestingly, expression of pGL-F and pGL-MG showed about 1.8 fold increase after 24 hours of C2-ceramide treatment but the relative induction of pGL-NF was reduced compared to pGL-F and pGL-MG. pGL-G and pGL-H did not show any difference to non-treated controls (Fig.6, B). 
A $\quad 1 \mathrm{~Kb}$

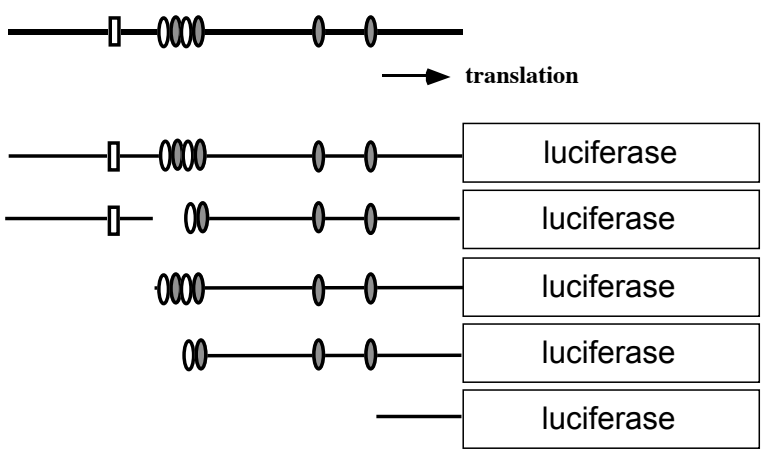

pGL-F

pGL-MG

pGL-NF

pGL-G

pGL-H
B

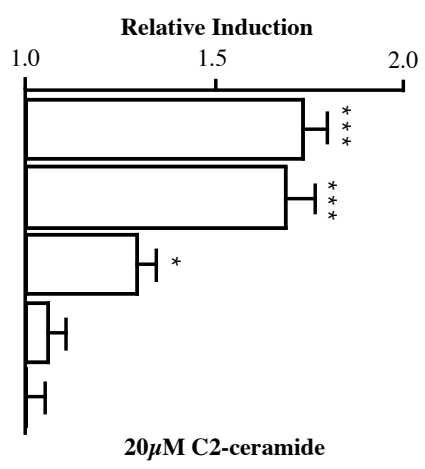

[] putative MR/GR binding site

0 putative NF-kB binding site

0 putative SP binding site

Fig. 6. Two putative NF-kappaB binding sites modulate SK2 transcription. A; Schematic map of SK2/luc vectors. B; Bar graphs show relative induction of luciferase activity after 24 hours treatment with $20 \mu \mathrm{M} \mathrm{C} 2$-ceramide. These bar graphs are normalized to cotransfected $B$-galactosidase. These data are the average of at least 8 measurements from 4 different transfection experiments. Data were expressed as mean \pm standard error (SEM). $* \mathrm{p}<0.05, * * * \mathrm{p}<0.0001$ by ANOVA with Fisher's PLSD post hoc test.

\section{Repression of NF-kappaB-induced SK2 Promoter Activity by glucocorticoid receptors}

To investigate whether glucocorticoid receptors interact with NF-kappaB and thereby affecting SK2 expression in PC12 cells, we treated C2-ceramide together with aldosterone or dexamethasone. Surprisingly, $25 \mathrm{nM}$ of dexamethasone downregulated C2-ceramide induced SK2 expression, whereas $750 \mathrm{nM}$ of dexamethasone had no effect. Aldosterone did not influence C2-ceramide-induced SK2 expression at any concentration (Fig.7). 

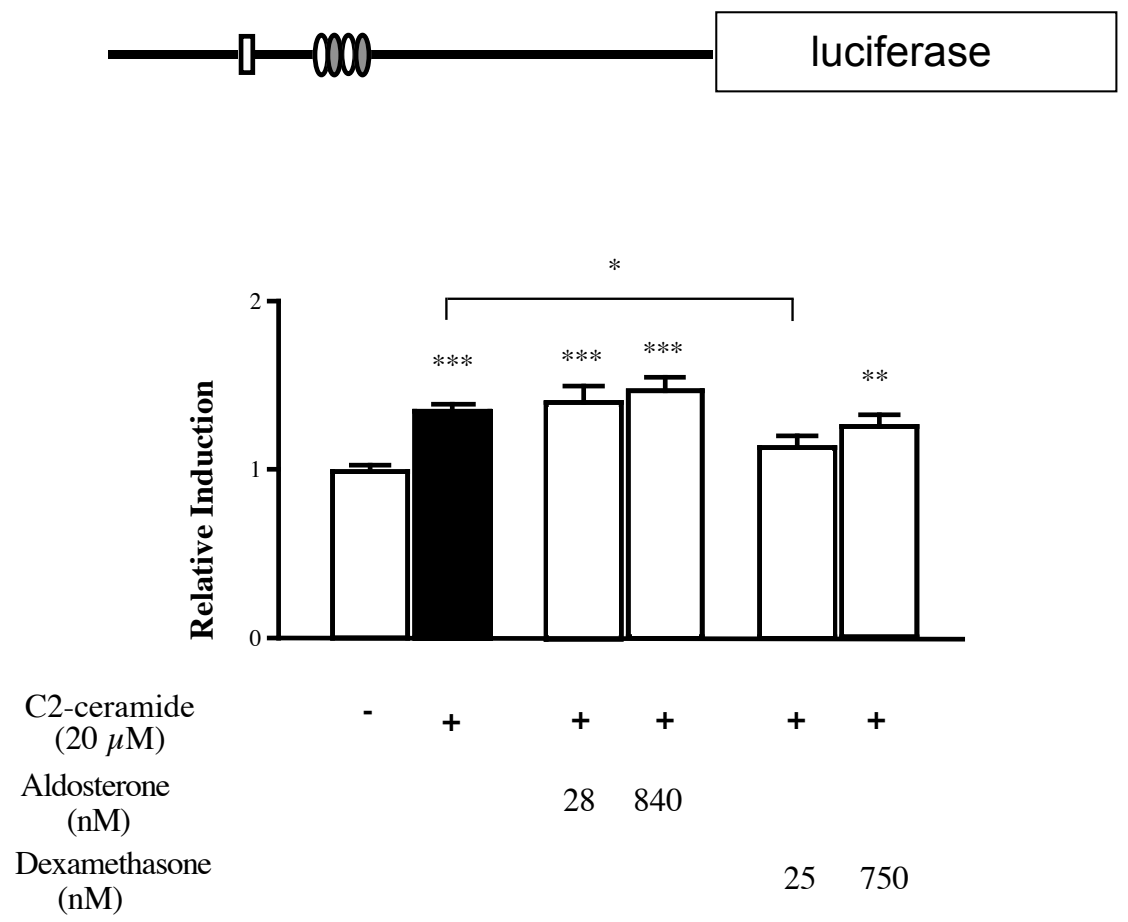

Fig. 7. Activated GR reduced C2-ceramide-induced SK2 up-regulation. Dexamethasone and aldosterone were applied to pGL-F expressing PC12 cells in the presence of C2ceramide. These data are the average of at least 8 measurements from 4 different transfection experiments. Data are expressed as mean \pm standard error (SEM); ${ }^{*} \mathrm{p}<0.05$, $* * \mathrm{p}<0.005, * * * \mathrm{P}<0.0001$ by ANOVA with Fisher's PLSD post hoc test.

On the other hand, after removal of the putative MR/GR binding site $25 \mathrm{nM}$ dexamethasone had no effect on SK2 expression, whereas $750 \mathrm{nM}$ of dexamethasone reduced ceramide induced SK2 expression. Again, aldosterone had no effect on pGL-NF expression (Fig.8). 

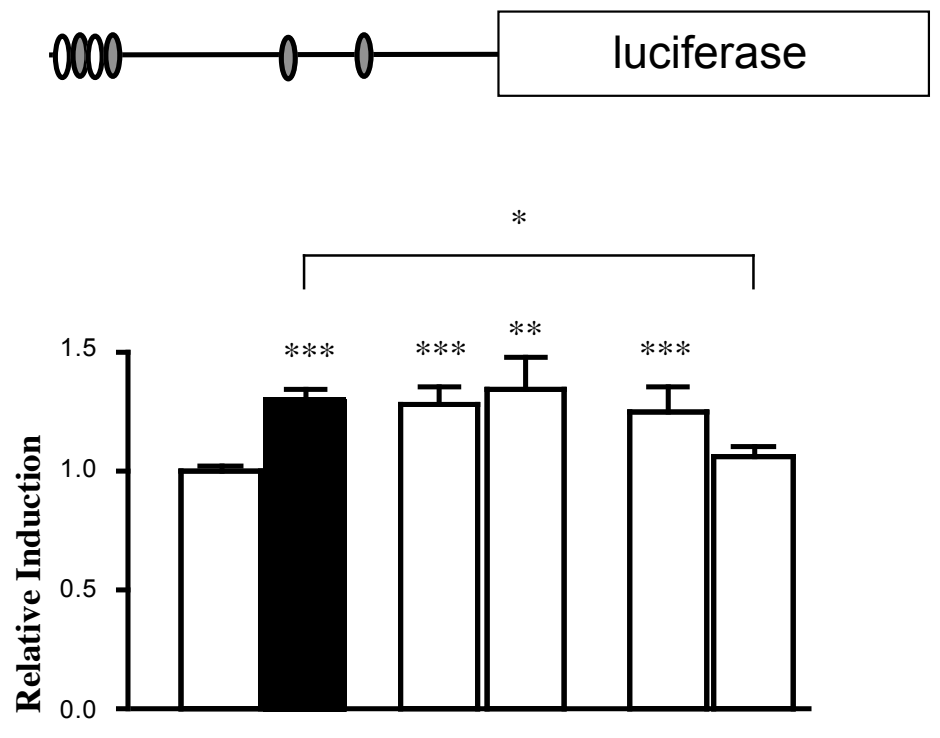

C2-ceramide

$(20 \mu \mathrm{M})$

Aldosterone

$(\mathrm{nM})$

Dexamethasone

$(\mathrm{nM})$

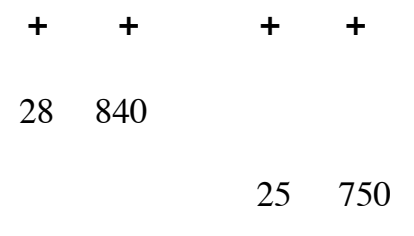

Fig.8. Activated GR reduced C2-ceramide induced SK2 up-regulation. Dexamethasone and aldosterone were applied to pGL-NF expressing PC12 cells in the presence of C2ceramide. These data are the average of at least 8 measurements from 4 different transfection experiments. Data are expressed as mean \pm standard error (SEM); $* \mathrm{p}<0.05$, $* * \mathrm{p}<0.005, * * * \mathrm{P}<0.0001$ by ANOVA with Fisher's PLSD post hoc test.

\section{Discussion}

Small conductance, calcium activated potassium channels were assumed to be responsible for afterhyperpolarization (AHP), which follow action potentials in neurons and control neuronal excitability. To gain more insight into the regulation of SK channel expression would help to understand the mechanisms underlying the modulation of neuronal signaling. Based on previous reports that neuronal signaling is changed after acute stress (Blank et al., 2002) and that it is modified by steroid hormones via genomic action (Joels et al., 1991; Karst et al., 1991) we anticipated a regulation of SK gene expression by corticosteroids. 
Three SK channel subtypes have been cloned from the mammalian brain (Köhler et al., 1996). They show high homology in sequence but their pharmacological properties are diverse. SK2 and SK3 channels are sensitive to the bee-venom toxin, apamin, whereas SK1 channels are insensitive (Ishii et al., 1997). They further show very different distribution pattern in the mammalian brain (Stocker and Pedarzani, 2000). The data presented here support the view that SK2 channels are target genes for corticosteroids and the transcription factor NF-kappaB.

Two kinds of corticosteroid receptors have been reported in mammalian cells, with highly different binding affinities to corticosteroids. Mineralocorticosteroid receptors (MR) have a 10 fold higher affinity to corticosterone than glucocorticoid receptors (GR) (for review, see de Kloet et al., 1998). Although they share the same ligand, corticosterone, they have different physiological functions and are expressed in different tissues. Both receptors share the same DNA binding motif. However, due to different transcription co-factors MRs and GRs have been reported to regulate distinct genes (Joels, 2001; de Kloet, 2003). We constructed various reporter vectors to determine the amount of SK2 transcription. pGLF, containing a putative MR/GR binding site, showed a dose-dependent activation in response to corticosterone. To identify the type of receptor involved in the activation of SK2 transcription, we applied selective MR and GR agonists. Interestingly both, aldosterone and dexamethasone enhanced SK2 expression in a receptor-dependent way.

NF-kappaB has been known as a transcriptional activator for several genes, which are mainly involved in immune reaction and apoptosis. But recently completely different implications have been reported such as neural plasticity and cellular protective effects against stress and cellular damages (for review, see Mattson, et al., 2000; Carroll et al, 1998; Clemens et al, 1997; Culmsee et al., 2003). We found two putative NF-kappaB binding sites in the 5' flanking region of the murine SK2 gene. There was no NF-kappaB baseline activity in PC12 cells but activation of NF-kappaB resulted in enhanced SK2 expression. When we constructed several SK2/luc vectors to investigate the role of two putative NF-kappaB binding sites we found that the region between the putative MR and GR sites and upstream of the putative NF-kappaB binding site was important for 
complete SK2 expression. This data suggest that other transcription co-factors or potential enhancers are necessary for NF-kappaB to become fully active.

Another interesting finding of this study is that there is an interaction between activated GRs and NF-kappaB to modulate SK2 expression. It has been described that the activity of NF-kappaB is regulated by several mechanisms (Zhao and Karalis, 2002). Activated GRs can increase SK2 expression directly, but at the same time, decrease NFkappaB mediated SK2 expression. At the moment it is unclear why activated GRs have opposite effects on the expression of the same gene. It can be speculated that this mechanism prevents SK2 over expression under conditions, which activate GRs and NFkappaB.

Since SK channels are gating potassium ions from the inside to the outside of the cell, they prevent neurons from tonic firing. It can be suggested that NF-kappaB counteracts neuronal hyperexcitability via regulation of SK2 channels and thus protects cells from damage. This is supported by a previous report, which showed that hippocampal cells overexpressing SK2 channels are more resistant to several kinds of cellular stressors (Lee et al., 2003). Our findings that expression of SK2 channel is regulated by stress hormones and NF-kappaB at the same time propose a protective role of SK2 channels for neurons experiencing various stressful stimuli.

\section{References}

Almawi WY and Melemedjian OK Negative regulation of nuclear factor-kappaB activation and function by glucocorticoids J Mol Endocrinol. (2002) 28(2): 69- 78

Baldwin AS Jr The NF-kappa B and I kappa B proteins: new discoveries and insights Annu Rev Immunol. (1996) 14: 649- 683

Blank T, Nijholt I, Grammatopoulos DK, Randeva HS, Hillhouse EW and Spiess J Corticotrophinreleasing factor receptors couple to multiple $\mathrm{G}$-proteins to activate diverse intracellular signaling pathways in mouse hippocampus: role in neuronal excitability and associative learning $\mathrm{J}$ Neurosci. (2003) 23: 700- 707

Blank T, Nijholt I, Eckart K and Spiess J Priming of long-term potentiation in mouse hippocampus by corticotropin-releasing factor and acute stress: implications for hippocampus-dependent learning $\mathrm{J}$ Neurosci. (2002) 22: 3788- 3794

Carroll JE, Howard EF, Hess DC, Wakade CG, Chen Q and Cheng C Nuclear factor-kappa B activation during cerebral reperfusion: effect of attenuation with $\mathbf{N}$-acetylcysteine treatment. Brain Res Mol Brain Res. (1998) 56(1-2): 186- 191 
Clemens JA, Stephenson DT, Smalstig EB, Dixon EP and Little SP Global ischemia activates nuclear factor-kappa B in forebrain neurons of rats. Stroke. (1997) 28(5): 1073- 1080; discussion 1080-1.

Culmsee C, Siewe J, Junker V, Retiounskaia M, Schwarz S, Camandola S, El-Metainy S, Behnke H, Mattson MP and Krieglstein $J$ Reciprocal inhibition of $\mathbf{p 5 3}$ and nuclear factor-kappaB transcriptional activities determines cell survival or death in neurons. J Neurosci. (2003) 23(24): 8586- 8595.

de Kloet ER Steroids, stability and stress Front Neuroendocrinol. (1995) 16: 416- 425

de Kloet ER Hormones, brain and stress Endocr Regul. (2003) 37(2): 51- 68

de Kloet ER, Oitzl MS and Joels M Functional implications of brain corticosteroid receptor diversity. Cell Mol Neurobiol. (1993) 13(4): 433- 455

de Kloet ER, Oitzl MS and Joels M Stress and cognition: are corticosteroids good or bad guys? Trends Neurosci. (1999) 10: 422- 426

de Kloet ER and Reul JM Feedback action and tonic influence of corticosteroids on brain function: a concept arising from the heterogeneity of brain receptor systems Psychoneuroendocrinology (1987) 12: 83-105

de Kloet ER, Rots NY, van den Berg DT and Oitzl MS Brain mineralocorticoid receptor function Ann N Y Acad Sci. (1994) 746: 8- 20

de Kloet ER, Sutanto W, Rots N, van Haarst A, van den Berg D, Oitzl M, van Eekelen A and Voorhuis D Plasticity and function of brain corticosteroid receptors during aging Acta Endocrinol (Copenh). (1991) 125: 65- 72

de Kloet ER, Vreugdenhil E, Oitzl MS and Joels M Brain corticosteroid receptor balance in health and disease Endocr Rev. (1998) 19: 269- 301

Faber ES and Sah P Physiological role of calcium-activated potassium currents in the rat lateral amygdala J Neurosci. (2002) 22: 1618- 1628

Goodman Y and Mattson MP Ceramide protects hippocampal neurons against excitotoxic and oxidative insults, and amyloid B-peptide toxicity J Neurochem (1996) 66: 869- 872

Grilli M, Pizzi M, Memo M and Spano P Neuroprotection by aspirin and sodium salicylate through blockade of NF-kappaB activation Science. (1996) 274(5291): 1383- 1385

Joels M Corticosteroid actions in the hippocampus J Neuroendocrinol. (2001) 13(8): 657- 669

Joels $\mathrm{M}$ and de Kloet ER Effect of corticosteroid hormones on electrical activity in rat hippocampus $\mathrm{J}$ Steroid Biochem Mol Biol. (1991) 40: 83- 86

Joels M, Hesen W and de Kloet ER Mineralocorticoid hormones suppress serotonin-induced hyperpolarization of rat hippocampal CA1 neurons J Neurosci. (1991) 11: 2288- 2294

Joels M, Velzing E, Nair S, Verkuyl JM and Karst H Acute stress increases calcium current amplitude in rat hippocampus: temporal changes in physiology and gene expression Eur J Neurosci. (2003) 18: 1315- 1324

Ishii TM, Maylie J and Adelman JP Determinants of apamin and d-tubocurarine block in SK potassium channels J Biol Chem. (1997) 272(37): 23195- 23200 
Karst $\mathrm{H}$ and Joels $\mathrm{M}$ The induction of corticosteroid actions on membrane properties of hippocampal CA1 neurons requires protein synthesis Neurosci Lett. (1991) 130: 27- 31

Karst H, Wadman WJ and Joels M Corticosteroid receptor-dependent modulation of calcium currents in rat hippocampal CA1 neurons Brain Res. (1994) 649: 234- 242

Kim JJ and Diamond DM The stressed hippocampus, synaptic plasticity and lost memories Nat Rev Neurosci. (2002) 3: 453- 462

Kohler M, Hirschberg B, Bond CT, Kinzie JM, Marrion NV, Maylie J and Adelman JP Smallconductance, calcium-activated potassium channels from mammalian brain Science (1996) 273(5282): 1709- 1714

Lee AL, Dumas TC, Tarapore PE, Webster BR, Ho DY, Kaufer D and Sapolsky RM Potassium channel gene therapy can prevent neuron death resulting from necrotic and apoptotic insults $J$ Neurochem. (2003) 86(5): 1079- 1088

Lin YZ, Yao SY, Veach RA, Torgerson TR and Hawiger J Inhibition of nuclear translocation of transcription factor NF-kappaB by a synthetic peptide containing a cell membrane-permeable motif and nuclear localization sequence J Biol Chem (1995) 270: 14255- 14258

Lorenzon NM and Foehring RC Relationship between repetitive firing and afterhyperpolarizations in human neocortical neurons J Neurophysiol. (1992) 67: 350- 363.

Madrigal JL, Moro MA, Lizasoain I, Lorenzo P, Castrillo A, Bosca L and Leza JC Inducible nitric oxide synthase expression in brain cortex after acute restraint stress is regulated by nuclear factor kappaBmediated mechanisms J Neurochem. (2001) 76(2): 532- 538

Mattson MP, Culmsee C, Yu ZF and Camandola S Roles of nuclear factor kappaB in neuronal survival and plasticity J Neurochem (2000) 74: 443- 465

McEwen BS, De Kloet ER and Rostene W Adrenal steroid receptors and actions in the nervous system Physiol Rev. (1986) 66: 1121- 1188

Prasad AV, Pilcher WH and Joseph SA Nuclear factor-kappaB in rat brain: enhanced DNA-binding activity following convulsant-induced seizures Neurosci Lett. (1994) 170(1): 145- 148

Sah P Ca(2+)-activated $\mathrm{K}+$ currents in neurones: types, physiological roles and modulation Trends Neurosci. (1996) 19: 150- 154

Sah $\mathrm{P}$ and Faber ES Channels underlying neuronal calcium-activated potassium currents Prog Neurobiol. (2002) 66: 345- 353

Sailer CA, Hu H, Kaufmann WA, Trieb M, Schwarzer C, Storm JF and Knaus HG Regional differences in distribution and functional expression of small-conductance Ca2+-activated $\mathrm{K}+$ channels in rat brain J Neurosci. (2002) 22(22): 9698- 9707

Salinas M, Lopez-Valdaliso R, Martin D, Alvarez A and Cuadrado A Inhibition of PKB/Akt1 by C2ceramide involves activation of ceramide-activated protein phosphatase in PC12 cells Mol Cell Neurosci. (2000) 15: 156-169

Salminen A, Liu PK and Hsu CY Alteration of transcription factor binding activities in the ischemic rat brain. Biochem Biophys Res Commun. (1995) 212(3): 939- 944 
Scuvee-Moreau J, Liegeois JF, Massotte L and Seutin V Methyl-laudanosine: a new pharmacological

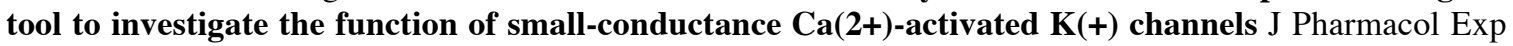
Ther. (2002) 302: 1176- 1183

Smith MA, Makino S, Kvetnansky R and Post RM Stress and glucocorticoids affect the expression of brain-derived neurotrophic factor and neurotrophin-3 mRNAs in the hippocampus J Neurosci. (1995) 15: $1768-1777$

Stackman RW, Hammond RS, Linardatos E, Gerlach A, Maylie J, Adelman JP and Tzounopoulos T Small conductance Ca2+-activated $\mathrm{K}+$ channels modulate synaptic

plasticity and memory encoding J Neurosci. (2002) 22: 10163- 10171

Stocker M, Krause M and Pedarzani P An apamin-sensitive Ca2+-activated K+ current in hippocampal pyramidal neurons Proc Natl Acad Sci U S A (1999) 96: 4662- 4667

Stocker M and Pedarzani P Differential distribution of three $\mathbf{C a}(2+)$-activated $\mathbf{K}(+)$ channel subunits, SK1, SK2, and SK3, in the adult rat central nervous system Mol Cell Neurosci. (2000) 15(5): 476- 493

Storm JF An after-hyperpolarization of medium duration in rat hippocampal pyramidal cells $J$ Physiol. (1989) 409: 171- 190

Tamatani M, Che YH, Matsuzaki H, Ogawa S, Okado H, Miyake S, Mizuno T and Tohyama M Tumer necrosis factor induces Bcl-2 and Bcl-x expression through NFपB activation in primary hippocampal neurons J Biol Chem (1999) 274: 8531- 8538

van Steensel B, van Binnendijk EP, Hornsby CD, van der Voort HT, Krozowski ZS, de Kloet ER and van Driel R Partial colocalization of glucocorticoid and mineralocorticoid receptors in discrete compartments in nuclei of rat hippocampus neurons. J Cell Sci. (1996) 109:787- 792

Villalobos C, Shakkottai VG, Chandy KG, Michelhaugh SK and Andrade R SKCa channels mediate the medium but not the slow calcium-activated afterhyperpolarization in cortical neurons $\mathrm{J}$ Neurosci. (2004) 24(14): 3537- 3542

Zhao J and Karalis KP Regulation of nuclear factor kappaB by corticotropin-releasing hormone in mouse thymocytes Mol Endocrinol. (2002) 16: 2561- 2570 


\section{Chapter 3}

\section{Transcriptional Regulation of the Calcium- Activated Potassium Channel SK2 Gene in Mouse Hippocampus}

\section{Introduction}

Small-conductance, calcium activated potassium channels are believed to underlie afterhyperpolarizations (AHPs), which controls neuronal excitability (Sah and Faber, 2002; Faber and Sah, 2002; Hosseini et al., 2001; Lorenzon and Foehring, 2002; Knaus et al., 2002). The control of excitability in neurons has been shown to be critical for various learning processes (Tzounopoulos and Stackman, 2003; Morozov et al., 2003; Power et al., 2002; Stackman et al., 2003) but is also essential to prevent neuronal hyperexcitability and subsequent neuronal damage. In view of these findings it is important to understand the regulation of SK channel gene expression because altered SK channel expression can be expected to directly interfere with neuronal excitability. In fact, several studies have shown that the electrophysiological properties of neurons are altered after an animal has been exposed to a stressful situation (Blank et al., 2002, 2003).

The hypothalamo-pituitary-adrenocortical (HPA) axis plays a vital role in adaptation of the organism to stress exposure. Activation of the HPA system culminates in secretion of corticosteroids, which are recognized by corticosteroids receptor molecules in numerous organ systems, and act by genomic mechanisms to modify transcription of key regulatory proteins (for review, see de Kloet et al., 1998). By crossing the blood-brain barrier, corticosteroids are also able to enter the brain (McEwen et al., 1986; De Kloet, 1991). Several studies have shown that corticosteroids affect the signaling properties of hippocampal neurons by modulating calcium current amplitudes 
(Joels et al., 1991), serotonin-induced hyperpolarizations (Karst et al., 1994; Joels et al., 2003) or afterhyperpolarizations (AHPs) (Joels et al., 1991; Karst et al., 1991).

Another transcription factor investigated in this study is nuclear factor-kappaB (NF-kappaB) (for review, see Mattson et al., 2000). It has been reported that the activity of NF-kappaB is regulated by the early stress hormone, CRF, and by corticosterone. Interestingly, CRF increases NF-kappaB activity while corticosterone inhibits it (Zhao and Karalis, 2002).

Here, we studied the effect of behavioral stress on the expression of SK2 in Balb/c and C57BL/6J mice.

\section{Materials and Methods}

\section{Animals and cannulation}

Experiments were carried out with young (8 weeks), male Balb/c (Charles River, Sultzfeld, Germany) and C57BL/6J mice (Harlan-Winkelmann, Borchen, Germany). Upon arrival the mice were individually housed and maintained on a $12 \mathrm{hr}$ light/dark cycle (lights on at 7 a.m.) with free access to food and water. Mice were kept under these housing conditions for at least two weeks before experiments were started. Double guide cannulae (C235, Plastics One, Roanoke, Virginia) were implanted using a stereotactic holder during $1.2 \%$ avertin anesthesia $(0.02 \mathrm{ml} / \mathrm{g}$, intraperitoneal $)$ under aseptic conditions as previously described (Blank et al., 2002). Each double guide cannula with inserted dummy cannula and dust cap was fixed to the skull of the mouse with dental cement. For intracerebroventricular (i.c.v.) injections cannulae were placed into both lateral brain ventricles, with anteroposterior (AP) coordinates zeroed at Bregma AP 0 $\mathrm{mm}$, lateral $1 \mathrm{~mm}$ and depth $3 \mathrm{~mm}$. Bilateral injections were performed using an infusion pump (CMA/100, CMA/Microdialysis, Solna, Sweden) at a constant rate of $0.5 \mu \mathrm{l} / \mathrm{min}$ (final volume: $1 \mu$ l per side). Alternatively, cannulae were directed toward dorsal hippocampi, AP-1.5mm, lateral 1mm and depth $2 \mathrm{~mm}$ (Franklin and Paxinos, 1997). Bilateral injections were performed using an infusion pump at a constant rate of 0.33 $\mu 1 /$ min (final volume: $1 \mu \mathrm{l}$ per side). The animals were allowed to recover for $4-5 \mathrm{~d}$ before the experiments started. 


\section{Immobilization stress}

An acute immobilization stress of mice consisted of taping their limbs to a plastic surface for 1 hour (Smith et al., 1995).

\section{Drug treatment}

Mice were injected subcutaneously with either the mineralocorticoid receptor (MR) antagonist spironolactone $(50 \mathrm{mg} / \mathrm{kg}$ ), the glucocorticoid receptor (GR) antagonist mifepristone $(25 \mathrm{mg} / \mathrm{kg}$ ) or the corresponding vehicle (physiological saline containing $1 \%$ polyethylene glycol 400) 30 min prior to immobilization. Subsequently, mice were briefly anesthetized with isoflurane and decapitated immediately or 2 hours after the stress session. Peptide NF-kappaB inhibitor (SN50, Santa Cruz, CA, USA) and its corresponding control peptide were dissolved in $0.9 \%$ saline with a final concentration of $50 \mu \mathrm{g} / \mathrm{ml}$. One microliter of solution was injected per mouse hippocampus. The final amount of injected peptide was $50 \mathrm{ng} /$ hippocampus. One hour after treatment, animals were briefly anesthetized with isoflurane and decapitated. All other drugs were purchased from Sigma (MO, USA).

\section{Collection of hippocampal tissue, RNA extraction and DNase I Treatment}

After decapitation, hippocampi were rapidly removed, frozen on liquid nitrogen and stored at $-80^{\circ} \mathrm{C}$. Total RNA was isolated from mouse hippocampi using the Micro RNA Isolation Kit (Stratagene, CA, USA) following the manufacturer's instruction and treated with RQ1 RNase-free DNase I (Promega, WI, USA) at $37^{\circ} \mathrm{C}$ for $45 \mathrm{~min}$. Subsequently we used Phenol/Chloroform extraction to remove DNaseI. This procedure was repeated twice. The concentration of RNA was measured by spectrophotometer.

\section{Semi-quantitative RT-PCR}

Semi-quantitative reverse transcriptase polymerase chain reaction (RT-PCR) was performed to quantify SK2 transcripts using SUPERSCRIPT ${ }^{\circledR}$ One-step RT-PCR with PLATINUM Tag (Invitrogen, CA, USA). Hypoxanthine phosphoribosyl transferase (HPRT) was used as housekeeping gene. Primer sequences were rSK2-f; 5' tccgacttaaatgaaaggag-3', rSK2-r; 5' -gctcagcattgtaggtgac-3', HPRT-up; 5' - 
cctgctggattacattaaagcactg-3' and HPRT-low; 5'-cctgaagtactcattatagtcaagg-3'. $1.5 \mu \mathrm{g}$ of RNA was used for each RT-PCR reaction. To amplify SK2 and HPRT transcripts, 2 mM $\mathrm{Mg}^{2+}$ concentration was optimal. The reverse transcriptase reaction was performed at $55^{\circ} \mathrm{C}$ for 25 minutes. PCR cycling was at $94^{\circ} \mathrm{C}$ for 15 seconds, annealing at $55^{\circ} \mathrm{C}$ for 30 seconds, extension at $72^{\circ} \mathrm{C}$ for 50 seconds and a final extension at $72^{\circ} \mathrm{C}$ for 10 minutes. Eighteen microliter of each sample was removed every 3 cycles from 24 to 33 cycles in each reaction to amplify SK2 and HPRT fragments. To investigate the effect of SN50, 1 $\mu \mathrm{g}$ of RNA was used for each RT-PCR reaction and $15 \mu \mathrm{l}$ per sample were removed every 3 cycles from 29 to 35 cycles in each reaction.

Primer sequences for NF-kappaB subunits, p50 and p65 were p50-3f; 5'gtgcgcggtggagacgaagtttat-3', p50-4r; 5'-ccgaagggctgggagaaggtg-3', p65-2f; 5'agctgcctcggtggggatga-3' and p65-2r; cagcctggtcccgtgaaata-3'. To amplify p50 fragments, a concentration of $2 \mathrm{mM} \mathrm{Mg}{ }^{2+}$ was optimal. For p65 fragments, we used a concentration of $2.8 \mathrm{mM} \mathrm{Mg}^{2+}$. For each RT-PCR reaction $1.5 \mu \mathrm{g}$ of RNA was used. The same RT-PCR and PCR conditions were used for SK2 and HPRT fragments. Every 3 cycles from cycle 31 to cycle 40 a sample of $18 \mu 1$ was removed in each PCR reaction. HPRT was used as control gene. Amplified PCR products were separated on $1.5 \%$ agarose gels with TrisBorate EDTA buffer and stained with ethidium bromide. Gels were captured as a digital image and quantified by densitometry (WinCam 2.2, Cybertech).

\section{Statistics}

Statistical comparisons were made using Students `t-test or ANOVA. All RT-PCR experiments were repeated at least twice. Data were expressed as mean \pm standard error (SEM). The significance was determined at the level of $p<0.05$.

\section{Results}

We used semi-quantitative RT-PCR to determine the relative amount of hippocampal mRNA coding for SK2 channels before and after restraint stress in Balb/c and C57BL/6J mice. Amplified fragments of SK2 mRNAs and of the HPRT control template gave products of expected size. The PCR products were further confirmed by 
DNA sequencing (data not shown). The effect of single immobilization for 1 hour on the expression of SK2 channel subunits was measured 2 hours after stress exposure. In Balb/c mice expression of SK2 mRNA was clearly elevated compared to naive controls, whereas immobilization had no effect on SK2 mRNA levels in C57BL/6J mice. Interestingly, baseline expression of SK2 mRNA was significantly different in hippocampi of both mouse strains (Fig. 1). The mRNA levels of the housekeeping gene HPRT were not affected by the stress stimulus (Fig. 1).

\section{Balb/c}

A

$$
\text { Naive }
$$

Stress+2hr

$\begin{array}{llll}24 & 27 & 30 & 33\end{array}$

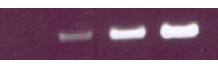

$24 \quad 27 \quad 30 \quad 33$

SK2

HPRT

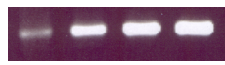

$\begin{array}{llll}24 & 27 & 30 & 33\end{array}$

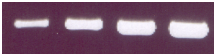

C57BL/6J

Naive

$30 \quad 333639$

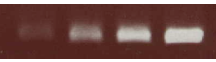

$24 \quad 27 \quad 30 \quad 33$

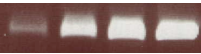

$-200 \div 1$ bp

Stress+2hr

$\begin{array}{llll}30 & 33 & 36 & 39\end{array}$

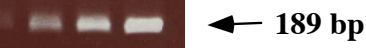

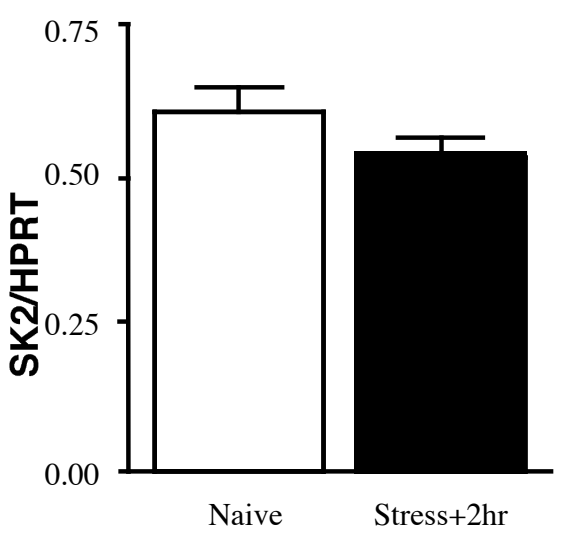

Fig. 1. The amount of SK2 transcript in hippocampi of BALB/c and C57BL/6J mouse strains. (a) Semi-quantitative RT-PCR of SK2 transcript and HPRT before and after 1hour immobilization stress in two mouse strains. (b) Relative amount of SK2 transcript normalized to the amount of the housekeeping gene HPRT. These data were from 8 mouse hippocampi and semi-quantitative RT-PCR was repeated at least three times. ** $\mathrm{P}<0.005$ versus naïve values by two-tailed Student's t-test. 
To further investigate the stress-induced changes in SK2 mRNA levels observed in hippocampi of Balb/c mice we subcutaneously injected mice with antagonists for GR (mifepristone) or MR (spironolactone) (Fig. 2). Thirty minutes after injection, animals were immobilized and the amount of hippocampal mRNA was analysed 1 and 2 hours following the stress session. Gene expression of SK2 subunits in Balb/c was clearly affected by both antagonists. As shown in Figs. 2 A and B, stress modulated SK2 channel expression in a biphasic and time-dependent manner. The amount of mRNA coding for SK2 was reduced immediately after the stress session, and was significantly elevated 2 hours later. Subcutaneous vehicle injection had no effect on the expression of SK2 mRNA compared to non-injected control. Spironolactone completely prevented the reduction of SK2 mRNA immediately after the stress session. In the presence of mifepristone the initial reduction of SK 2 mRNA observed immediately after 1hour of immobilization was turned into a significant enhancement when compared to naive levels (Fig. 2 C, D). 
A
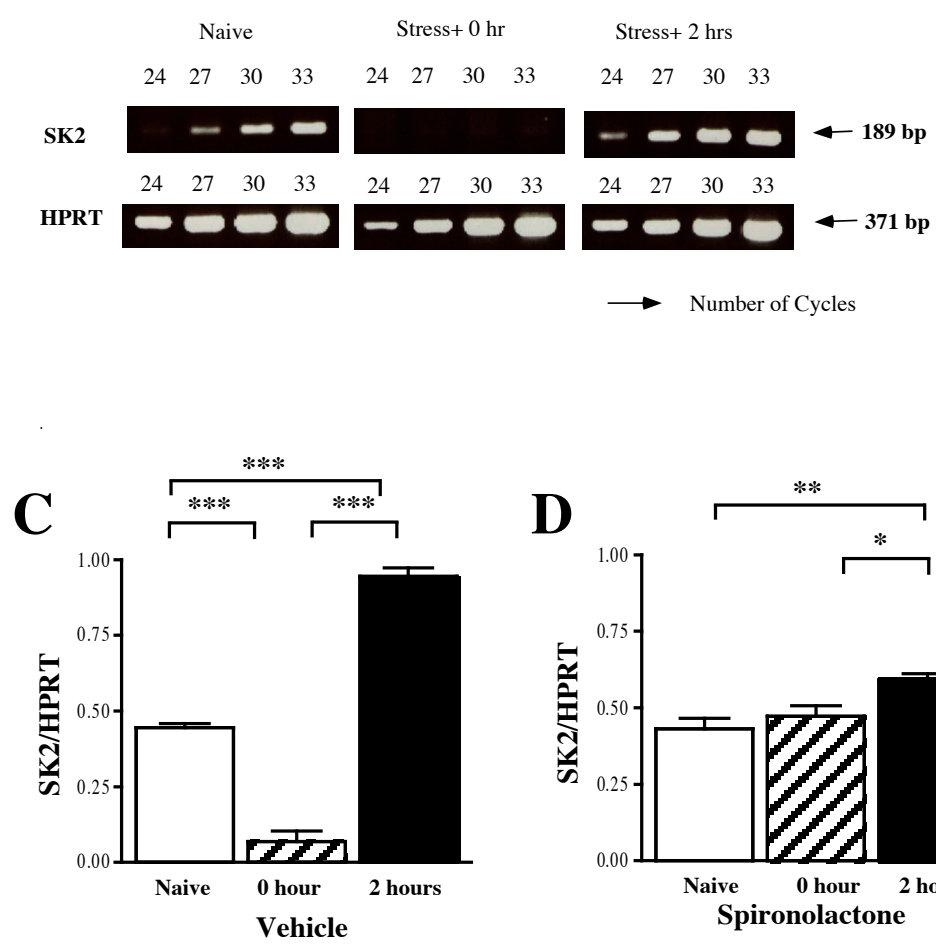

D

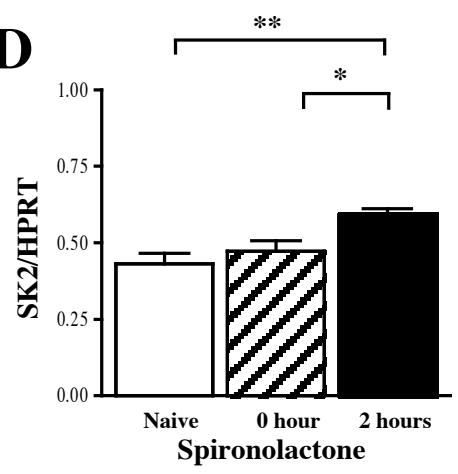

B
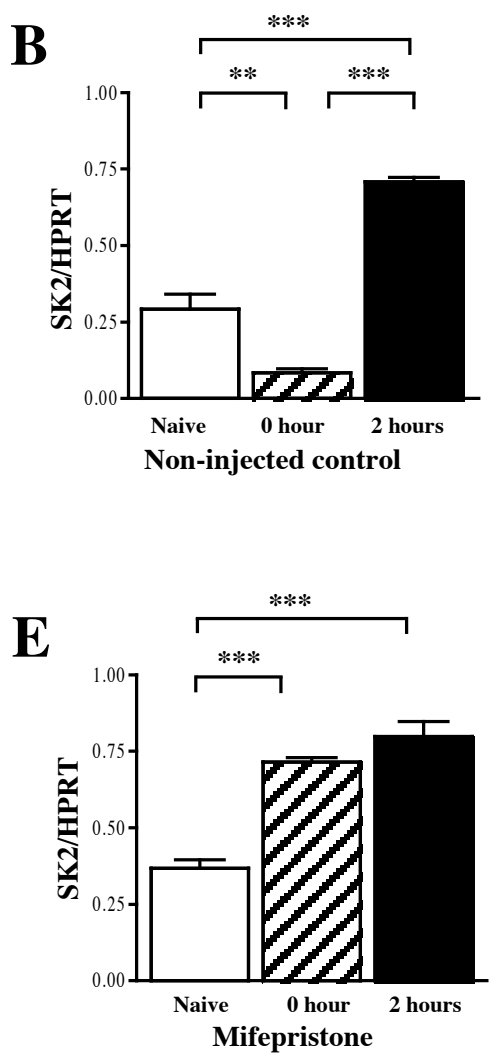

Fig. 2. The amount of SK2 transcript in mouse hippocampus is highly changed after stress in Balb/c mice. (a) Semi-quantitative RT-PCR of SK2 and HPRT transcripts in non-injected control. (b) Bar graphs show the relative amount of SK2 transcript normalized to the amount of the housekeeping gene HPRT before and after one hour immobilization without any injection. (c) Stress-induced changes in SK2 expression in the presence of vehicle, (d) spironolactone or (e) mifepristone. All drugs were treated systemically 30 minutes before immobilization session. These data are from at least 8 mouse hippocampi and semi-quantitative RT-PCR was repeated at least three times. * $\mathrm{p}<0.05, * * \mathrm{p}<0.005, * * * \mathrm{p}<0.0001$ by ANOVA.

We determined the amounts of NF-kappaB subunits in mouse hippocampus using semi-quantitative RT-PCR. Interestingly, hippocampi of Balb/c mice had higher amounts of the NF-kappaB subunit, p50, when compared to the amounts found in hippocampi of C57BL/6J mice. The amount of an additional NF-kappaB subunit, p65, was identical in both strains (Fig. 3). When we injected $50 \mathrm{ng}$ of the specific NF-kappaB peptide inhibitor SN50 (Lin et al., 1995) into the mouse hippocampus it downregulated the transcription of SK2 channels in the hippocampus of both strains (Fig.4). 
A

p50

p65

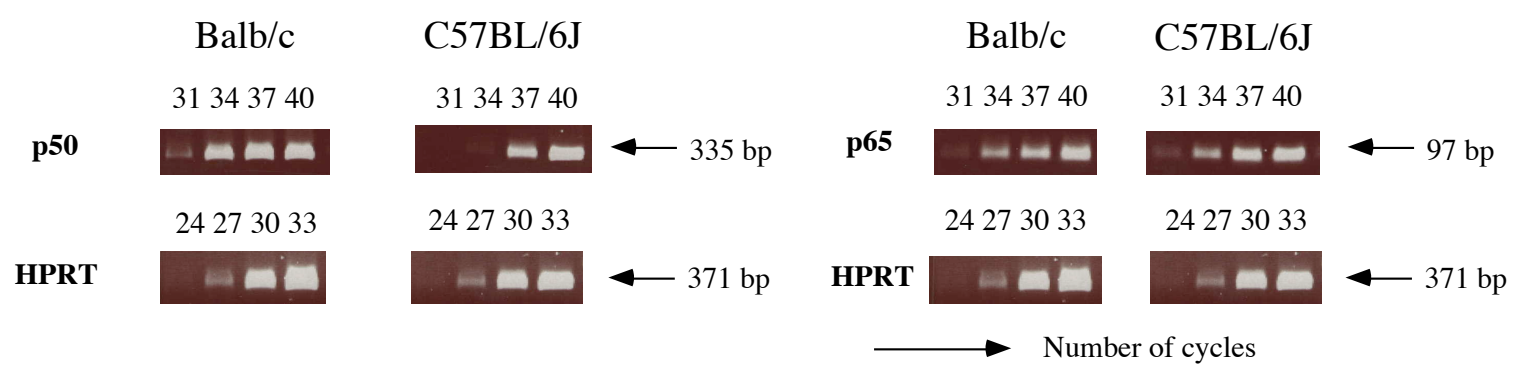

B
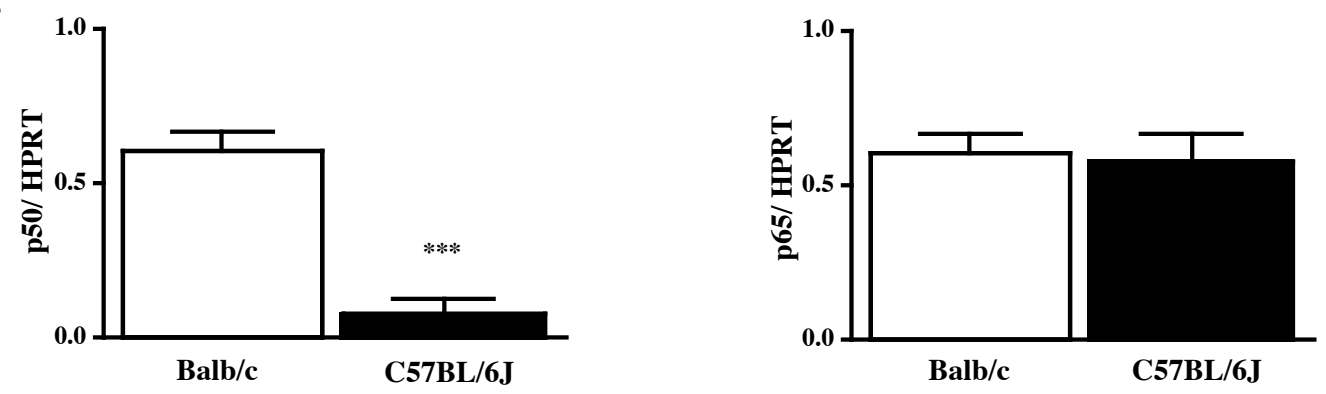

Fig. 3 Balb/c mice have more p50 than C57BL/6J. (a) Semi-quantitative RT-PCR show the amount of NF-kappaB subunits p50 and p65 transcripts in the hippocampus of both mouse strains. (b) Bar graphs show the relative amount of p50 and p65 normalized to the amount of HPRT transcripts. These data are from at least 6 mouse hippocampi and semiquantitative RT-PCR was repeated at least three times. ${ }^{* * *} \mathrm{p}<0.0001$ versus $\mathrm{Balb} / \mathrm{c}$ by two-tailed Student's t-test. 
A

$2932 \quad 35$

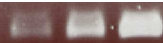

$2932 \quad 35$

29

Balb/c

$\begin{array}{llllll}29 & 32 & 35 & 29 & 32 & 35\end{array}$

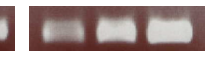

$2932 \quad 35$

293235

$\square \square$

\section{C57BL/6J}

$\begin{array}{lllllllll}29 & 32 & 35 & 29 & 32 & 35 & 29 & 32 & 35\end{array}$

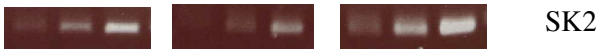

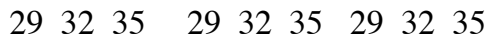

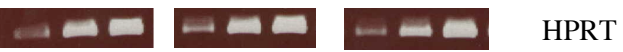

\section{B}
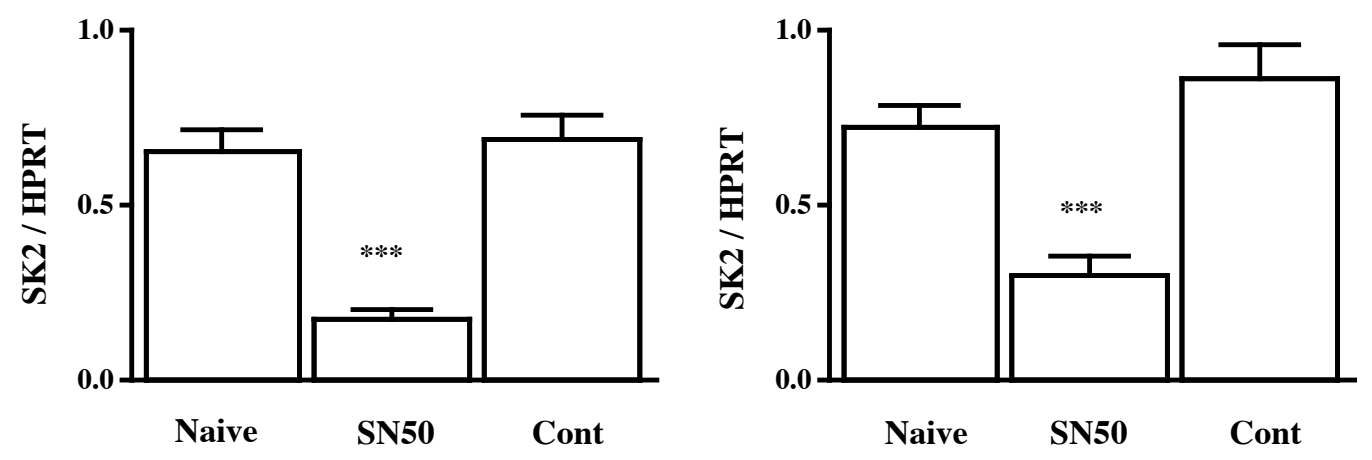

Fig.4 The specific peptide inhibitor SN50 reduced the amount of mRNA coding for SK2 channels in mouse hippocampus. (a) Semi-quantitative RT-PCR shows relative amounts of SK2 transcripts in hippocampi of both mouse strains. (b) Bar graphs show the relative amount of SK2 transcript normalized to the amount of HPRT transcripts. These data are from at least 6 mouse hippocampi and semi-quantitative RT-PCR was repeated at least three times. $* * * \mathrm{p}<0.0001$ versus control peptide using ANOVA.

\section{Discussion}

A key feature of SK channels in the central nervous system is the contribution to an AHP that follows either single or trains of action potentials thus regulating neuronal excitability (Sah, 1996). The data presented here support the view that hippocampal SK2 channels are target genes for corticosteroids and NF-kappaB.

Surprisingly, there are significant differences in the hippocampal expression of SK2 under baseline conditions and after stress in both mouse strains. First of all naïve Balb/c mice have more SK2 mRNA when compared to naïve C57BL/6J mice. Following stress exposure we observed dramatic fluctuations in the expression of SK2 in Balb/c 
mice, whereas SK2 mRNA levels were unchanged in C57BL/6J. From our data it might be assumed that in Balb/c mice activated MRs work as an activator of SK2 channel expression in contrast to activated GRs, which seem to repress expression of SK2.

Another transcription factor modulating expression of SK2 channels is NFkappaB. The specific peptide inhibitor of NF-kappaB, SN50, clearly repressed expression of SK2 channels in hippocampi of both mouse strains, suggesting that NF-kappaB functions as an activator. While the amount of p50 mRNA was higher in hippocampi of Balb/c mice when compared to hippocampi of C57BL/6J mice, the amount of p65 mRNA was identical in both mouse strains. This difference might be responsible for the observation that hippocampi of Balb/c mice express more SK2 mRNA than hippocampi of $\mathrm{C} 57 \mathrm{BL} / 6 \mathrm{~J}$ mice.

One of the most interesting findings of this study is that the expression and regulation of SK2 channels are substantially different between the two mouse strains. One possible explanation might be that there are different regulatory sites in the upstream region of SK2 channels. It is also conceivable that both mouse strains show differences in their HPA axis responsiveness, which might result in dissimilar elevation of corticosterone levels following immobilization. In general, increased SK2 channel expression appears to represent a protective mechanism by lowering neuronal excitability. According to this hypothesis it was recently shown that overexpression of SK2 channels in cultured hippocampal neurons can protect cells against excitotoxicity (Lee et al., 2003).

In summary, expression of SK2 channels in mouse hippocampus is modulated by two endogenous corticosterone receptors and NF-kappaB. However, some questions still remain. First of all, why was the expression of SK2 channels in the hippocampus of C57BL/6J mice not changed after immobilization? It is very unlikely that corticosterone levels were not sufficient because one hour immobilization is generally regarded as a severe stressor. It seems as if the effect of corticosterone on SK2 transcription in the hippocampus of C57BL/6J mice was antagonized by additional transcription co-factors. As a result, the total amount of SK2 transcripts was kept constant. Another unanswered question is related to the activity of NF-kappaB in both mouse strains. It has been reported that the activity of NF-kappaB is changed after stress or aging (Korhonen et al., 
1997; Toliver-Kinsky et al., 1997, 2002). Based on this observation, it can be speculated that in both mouse strains stress exposure may have a different impact on the activity of NF-kappaB. These interstrain variations may help to further understand cellular mechanisms responsible for regulating gene expression in diverse genetic backgrounds.

\section{References}

Akinci MK and Johnston GA Sex differences in acute swim stress induced changes in the binding of AMPA (alpha-amino-3-hydroxy-5-methylisoxazole-4-propionic acid) and kainate to glutamate receptors in mouse forebrain Neurochem Int. (1994) 25: 169- 174

Blank T, Nijholt I, Eckart K and Spiess J Priming of long-term potentiation in mouse hippocampus by corticotropin-releasing factor and acute stress: implications for hippocampus-dependent learning $\mathrm{J}$ Neurosci. (2002) 22(9): 3788- 3794

Blank T, Nijholt I, Grammatopoulos DK, Randeva HS, Hillhouse EW and Spiess J Corticotrophinreleasing factor receptors couple to multiple G-proteins to activate diverse intracellular signaling pathways in mouse hippocampus: role in neuronal excitability and associative learning $\mathrm{J}$ Neurosci. (2003) 23: 700- 707

Bui NT, Livolsi A, Peyron JF and Prehn JH Activation of nuclear factor kappaB and Bcl-x survival gene expression by nerve growth factor requires tyrosine phosphorylation of IkappaBalpha $\mathrm{J}$ Cell Biol. (2001) 152(4): 753- 764

Cameron HA and Gould E Adult neurogenesis is regulated by adrenal steroids Neuroscience (1994) 61: 203- 209

de Kloet ER Steroids, stability and stress Front Neuroendocrinol. (1995) 16: 416- 425

de Kloet ER, Oitzl MS and Joels M Stress and cognition: are corticosteroids good or bad guys? Trends Neurosci. (1999) 10: 422- 426

de Kloet ER and Reul JM Feedback action and tonic influence of corticosteroids on brain function: a concept arising from the heterogeneity of brain receptor systems Psychoneuroendocrinology (1987) 12: 83-105

de Kloet ER, Rots NY, van den Berg DT and Oitzl MS Brain mineralocorticoid receptor function Ann N Y Acad Sci. (1994) 746: 8- 20

de Kloet ER, Vreugdenhil E, Oitzl MS and Joels M Brain corticosteroid receptor balance in health and disease Endocr Rev. (1998) 19: 269- 301

Faber ES and Sah P Physiological role of calcium-activated potassium currents in the rat lateral amygdala J Neurosci. (2002) 22: 1618- 1628

Goodman Y, Bruce AJ, Cheng B and Mattson MP Estrogens attenuate and corticosterone exacerbates excitotoxicity, oxidative injury, and amyloid B-peptide toxicity in hippocampal neurons $\mathrm{J}$ Neurochem (1996) 66: 1836- 1844

Goodman Y and Mattson MP Ceramide protects hippocampal neurons against excitotoxic and oxidative insults, and amyloid B-peptide toxicity J Neurochem (1996) 66: 869- 872 
Hosseini R, Benton DC, Dunn PM, Jenkinson DH and Moss GW SK3 is an important component of $\mathbf{K}(+)$ channels mediating the afterhyperpolarization in cultured rat SCG neurons J Physiol. (2001) 535: $323-334$

Howard SA, Nakayama AY, Brooke SM and Sapolsky RM Glucocorticoid modulation of gp120-induced effects on calcium-dependent degeneration events in primary hippocampal and cortical cultures Exp Neurol. (1999) 158: 164- 170

Joels $\mathrm{M}$ and de Kloet ER Effect of corticosteroid hormones on electrical activity in rat hippocampus $\mathrm{J}$ Steroid Biochem Mol Biol. (1991) 40: 83- 86

Joels M, Hesen W and de Kloet ER Mineralocorticoid hormones suppress serotonin-induced hyperpolarization of rat hippocampal CA1 neurons J Neurosci. (1991) 11: 2288- 2294

Joels M, Velzing E, Nair S, Verkuyl JM and Karst H Acute stress increases calcium current amplitude in rat hippocampus: temporal changes in physiology and gene expression Eur J Neurosci. (2003) 18: 1315- 1324

Karst $\mathrm{H}$ and Joels $\mathrm{M}$ The induction of corticosteroid actions on membrane properties of hippocampal CA1 neurons requires protein synthesis Neurosci Lett. (1991) 130: 27- 31

Karst H, Wadman WJ and Joels M Corticosteroid receptor-dependent modulation of calcium currents in rat hippocampal CA1 neurons Brain Res. (1994) 649: 234- 242

Korhonen P, Helenius $\mathrm{M}$ and Salminen A Age-related changes in the regulation of transcription factor NF-kappa B in rat brain. Neurosci Lett. (1997) 225: 61- 64

Krause M, Offermanns S, Stocker M and Pedarzani P Functional specificity of $\mathbf{G}$ alpha $\mathbf{q}$ and $\mathbf{G}$ alpha 11 in the cholinergic and glutamatergic modulation of potassium currents and excitability in hippocampal neurons J Neurosci. (2002) 22: 666- 673

Lee AL, Dumas TC, Tarapore PE, Webster BR, Ho DY, Kaufer D and Sapolsky RM Potassium channel gene therapy can prevent neuron death resulting from necrotic and apoptotic insults $J$ Neurochem. (2003) 86:1079- 1088

Lorenzon NM and Foehring RC Relationship between repetitive firing and afterhyperpolarizations in human neocortical neurons J Neurophysiol. (1992) 67: 350- 363.

Krugers HJ, Koolhaas JM, Bohus B and Korf $\mathbf{J}$ A single social stress-experience alters glutamate receptor-binding in rat hippocampal CA3 area Neurosci Lett. (1993) 154: 73- 77

Lezoualc'h F, Engert S, Berning B and Behl C Corticotropin-releasing hormone mediated neuroprotection against oxidative stress is associated with the increased release of non-amyloidogenic amyloid B precursor protein and with the suppression of nuclear factor -kB Mol. Endocrinol. (2000) 14: $147-159$

Lin YZ, Yao SY, Veach RA, Torgerson TR and Hawiger J Inhibition of nuclear translocation of transcription factor NF- $\square$ B by a synthetic peptide containing a cell membrane-permeable motif and nuclear localization sequence J Biol Chem (1995) 270: 14255- 14258

Mattson MP, Culmsee C, Yu ZF and Camandola S Roles of nuclear factor $\square \mathrm{B}$ in neuronal survival and plasticity J Neurochem (2000) 74: 443- 465

McEwen BS, De Kloet ER and Rostene W Adrenal steroid receptors and actions in the nervous system Physiol Rev. (1986) 66: 1121- 1188 
Morozov A, Muzzio IA, Bourtchouladze R, Van-Strien N, Lapidus K, Yin D, Winder DG, Adams JP, Sweatt JD and Kandel ER Rap1 couples cAMP signaling to a distinct pool of p42/44MAPK regulating excitability, synaptic plasticity, learning, and memory. Neuron (2003) 39(2): 309- 325

Power JM, Wu WW, Sametsky E, Oh MM and Disterhoft JF Age-related enhancement of the slow outward calcium-activated potassium current in hippocampal CA1 pyramidal neurons in vitro J Neurosci. (2002) 22(16): 7234- 7243

Sah P Ca(2+)-activated $\mathrm{K}+$ currents in neurones: types, physiological roles and modulation Trends Neurosci. (1996) 19: 150- 154

Sah $\mathrm{P}$ and Faber ES Channels underlying neuronal calcium-activated potassium currents Prog Neurobiol. (2002) 66: 345- 353

Salinas M, Lopez-Valdaliso R, Martin D, Alvarez A and Cuadrado A Inhibition of PKB/Akt1 by C2ceramide involves activation of ceramide-activated protein phosphatase in PC12 cells Mol Cell Neurosci. (2000) 15: 156-169

Scuvee-Moreau J, Liegeois JF, Massotte L and Seutin V Methyl-laudanosine: a new pharmacological tool to investigate the function of small-conductance $\mathbf{C a}(2+)$-activated $\mathbf{K}(+)$ channels $\mathrm{J}$ Pharmacol Exp Ther. (2002) 302: 1176- 1183

Smith MA, Makino S, Kvetnansky R and Post RM Stress and glucocorticoids affect the expression of brain-derived neurotrophic factor and neurotrophin-3 mRNAs in the hippocampus J Neurosci. (1995) 15: $1768-1777$

Stackman RW, Hammond RS, Linardatos E, Gerlach A, Maylie J, Adelman JP and Tzounopoulos T Small conductance $\mathrm{Ca} 2+$-activated $\mathrm{K}+$ channels modulate synaptic plasticity and memory encoding $\mathrm{J}$ Neurosci. (2002) 22: 10163- 10171

Stocker M, Krause M and Pedarzani P An apamin-sensitive Ca2+-activated K+ current in hippocampal pyramidal neurons Proc Natl Acad Sci U S A (1999) 96: 4662- 4667

Storm JF An after-hyperpolarization of medium duration in rat hippocampal pyramidal cells $\mathrm{J}$ Physiol. (1989) 409: 171- 190

Storm JF Potassium currents in hippocampal pyramidal cells Prog Brain Res. (1990) 83: 161 - 187

Tamatani M, Che YH, Matsuzaki H, Ogawa S, Okado H, Miyake S, Mizuno T and Tohyama M Tumer necrosis factor induces Bcl-2 and Bcl-x expression through NF $\square \mathrm{B}$ activation in primary hippocampal neurons J Biol Chem (1999) 274: 8531- 8538

Toliver-Kinsky T, Rassin D and Perez-Polo JR NF-kappaB activity decreases in basal forebrain of young and aged rats after hyperoxia Neurobiol Aging. (2002) 23: 899- 905

Toliver-Kinsky T, Papaconstantinou J and Perez-Polo JR Age-associated alterations in hippocampal and basal forebrain nuclear factor kappa B activity. J Neurosci Res. (1997) 48: 580- 587

Tzounopoulos $\mathrm{T}$ and Stackman R Enhancing synaptic plasticity and memory: a role for smallconductance Ca(2+)-activated K+ channels Neuroscientist. (2003) 9(6): 434- 439 Review.

Van Eekelen JA and De Kloet ER Co-localization of brain corticosteroid receptors in the rat hippocampus Prog Histochem Cytochem (1992) 26: 250- 258

Wossink J, Karst H, Mayboroda $\mathrm{O}$ and Joels $\mathrm{M}$ Morphological and functional properties of rat dentate granule cells after adrenalectomy Neuroscience (2001) 9: 125- 133 
Zhao J and Karalis KP Regulation of nuclear factor $\square \mathrm{B}$ by corticotropin-releasing hormone in mouse thymocytes Mol Endocrinol. (2002) 16: 2561- 2570 


\section{Chapter 4}

\section{The small conductance calcium-activated potassium channel SK3 generates age-related memory and LTP deficits}

Nature Neuroscience 2003 Sep 6(9): 911-2

Cognitive deficits are among the most devastating changes associated with the aging process. The decrement in learning specific learning tasks (Houston, 1999; Barnes, 1980) is correlated with substantial changes in neuronal signal processing in the hippocampus. (Landfield, et al., 1978, 1984; Wu, et al., 2000) Here, we show that elevated expression of small-conductance $\mathrm{Ca}^{2+}$-activated $\mathrm{K}^{+}$channels (SK channels) of the SK3 type in hippocampi of aged mice contributes to reduced long-term potentiation (LTP) and impaired trace fear conditioning, a hippocampus-dependent learning task. (McEchron, et al., 1998; Wallenstein, et al., 1998) SK channels modulate membrane excitability and are important determinants of the firing properties of central neurons. (Storm, 1990; Sah, et al., 1996; Pedarzani, et al., 2001; Schumacher, 2002) Recent immunohistological studies of SK3 channels revealed that they are highly expressed in rat hippocampus. (Tacconi, 2002)

We performed semi-quantitative RT-PCR (Fig. 1a,b) and Western blot analysis (Fig. 1d,e) of mouse hippocampus and showed that the SK3 channel transcript and protein are more abundant in hippocampi from aged mice (22-24 months) when compared to hippocampi from young mice (4-6 months). 
a
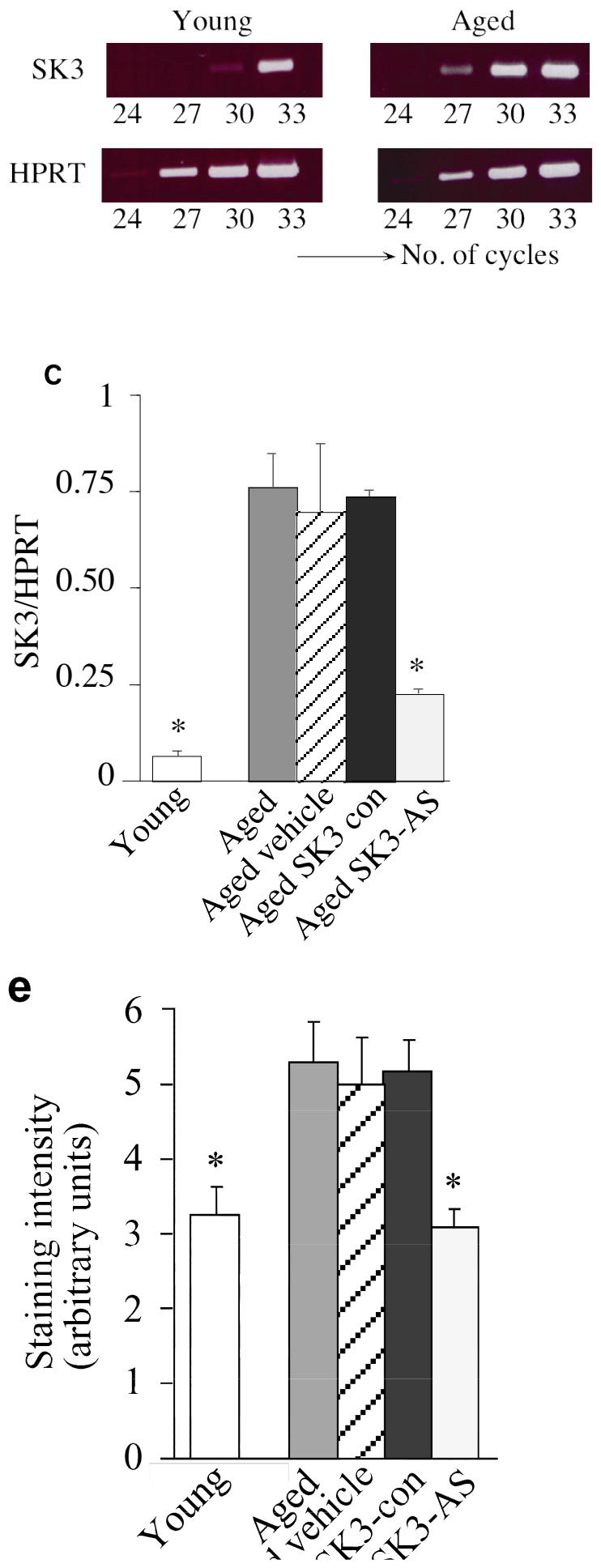

b

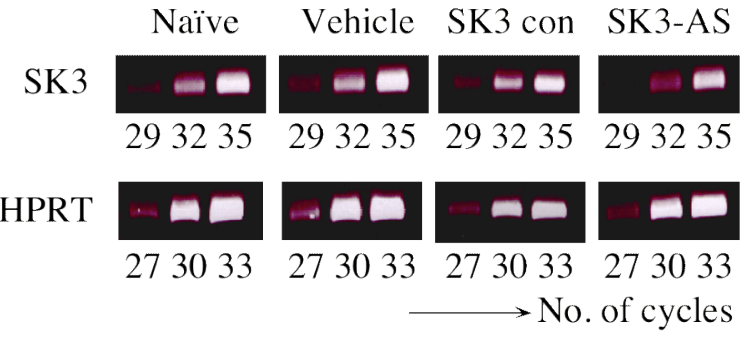

d

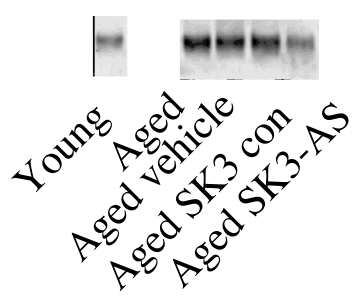


Figure 1 Antisense-SK3 treatment reduced the elevated expression of hippocampal SK3 channels in aged mice. (a) A typical RT-PCR experiment with SK3-specific primers (forward 5'-GTGCACAACTTCATGATGGA-3' and reverse 5' TTGACACCCCTCAGTTGG-3') revealed PCR products with the predicted 181-bp length of SK3 mRNA. Total RNA was extracted from a single hippocampus of a young and aged mouse. (b) Bar graphs show the relative band intensities on the basis of densitometric analysis as ratios of SK3 and HPRT mRNA after 30 cycles of coamplification (mean \pm SEM). The intensities were verified to be within the linear range of product accumulation. For each group, we used 5-11 mRNA samples. Statistical analysis was performed by a two-tailed Student's $t$-test. *Significance $(P<0.02)$. (c) The SK3 channel transcript was detected by RT-PCR in hippocampi from aged mice as described under (a). Antisense-SK3 injection resulted in a significant reduction of the amount of hippocampal SK3 mRNA $(* P<0.05$ by repeated measures ANOVA) relative to the amount detected in hippocampi from naïve, vehicle-injected or control ODNsinjected aged mice. One typical experiment of each group is presented. (d) Representative Western blot showing the analysis of SK3 protein in homogenates from a single hippocampus isolated from young or aged mice, which were pre-injected with vehicle, control oligonucleotides (ODNs) or antisense-SK3. (e) Bars represent mean Western blot band intensities \pm SEM from the hippocampal homogenates $(n=6$, $* P<$ 0.001 by ANOVA with Fisher's PLSD post hoc test).

To determine if the elevated SK3 channel expression in aged mice affects memory formation, mice were subjected to delay or trace fear conditioning (Supplementary Materials and Methods; all experiments were carried out in accordance with the European Council Directive of November 24, 1986 (86/609/EEC) with the permission (No. 604.42502/02-02.97) of the Animal Protection Law enforced by the District Government of Braunschweig, State of Lower Saxony, Germany). Trace conditioning is a hippocampus-dependent form of associative learning in which the conditioned stimulus (tone) and the unconditioned stimulus (footshock) are separated by a defined time interval. For delay conditioning, the tone is immediately followed by a footshock. Young and aged mice were tested 24 hours after delay fear conditioning in an altered context and did not differ in their freezing response to tone (Fig. 2a). This result suggests that acquisition and retention of the conditioned fear response were similarly intact in young and aged mice. The ability of young and aged mice to acquire associations between unpaired events was assessed in trace fear conditioning. In our protocol of trace fear conditioning, tone and shock were separated by a $15 \mathrm{~s}$ time interval. When tested 24 hours later, the freezing response of aged mice to the tone was reduced as 
compared to that of young mice (Fig. 2b), suggesting reduced hippocampal processing of the temporally discontiguous stimuli in aged mice. To test whether downregulation of SK3 channels in the hippocampus of aged mice would overcome this memory deficit, bilaterally cannulated mice were infused with either SK3 antisense oligonucleotides (ODNs) or control ODNs on day 5, 3 and 1 before behavioral training (Supplementary Materials and Methods). ODNs and vehicle injection before training did not affect overall activity and response to the footshock during the training session (not shown). When tested 24 hours after trace fear conditioning, however, aged mice treated with antisense ODNs against SK3 showed the same freezing response to tone as young animals. Injection of vehicle or control ODNs had no effect on freezing to tone (Fig. 2b). In a similar set of experiments, hippocampal tissue was taken and assayed for the SK3 channel transcript (Figs. 1c and b) and its encoded protein (Figs. 1d and e). Both SK3 channel transcript and protein production were reduced by injection of SK3 antisense ODNs in aged mice, whereas no effect on the amount of SK3 channel transcript and protein was observed after vehicle or control ODNs treatment.

a

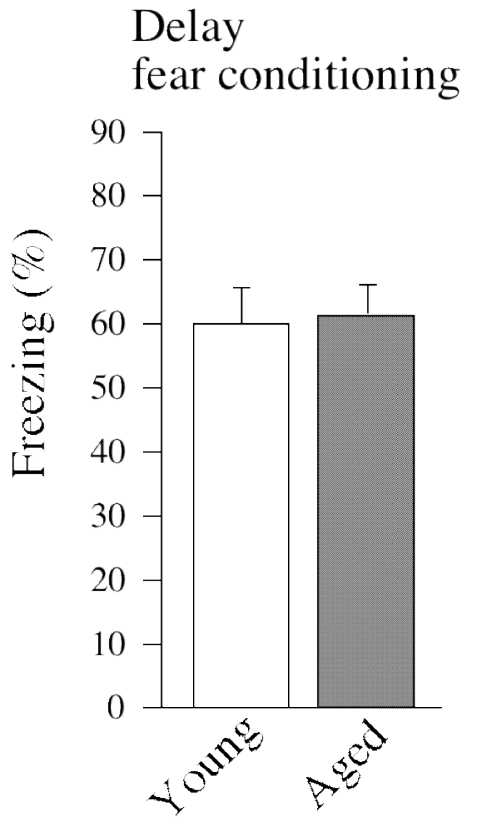

b

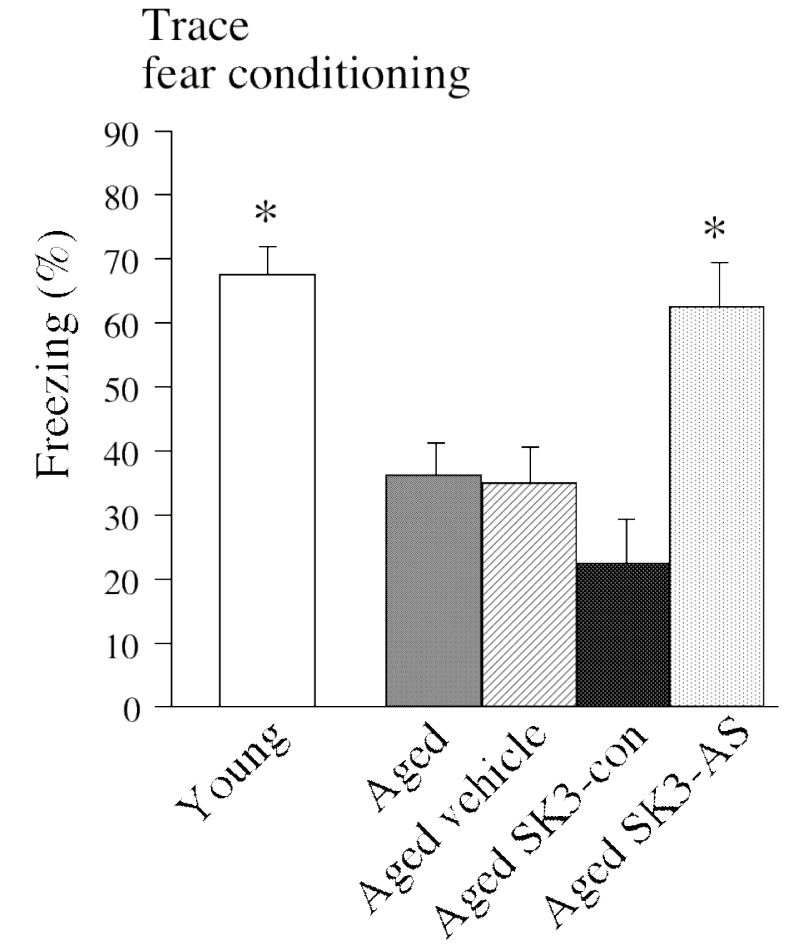


C
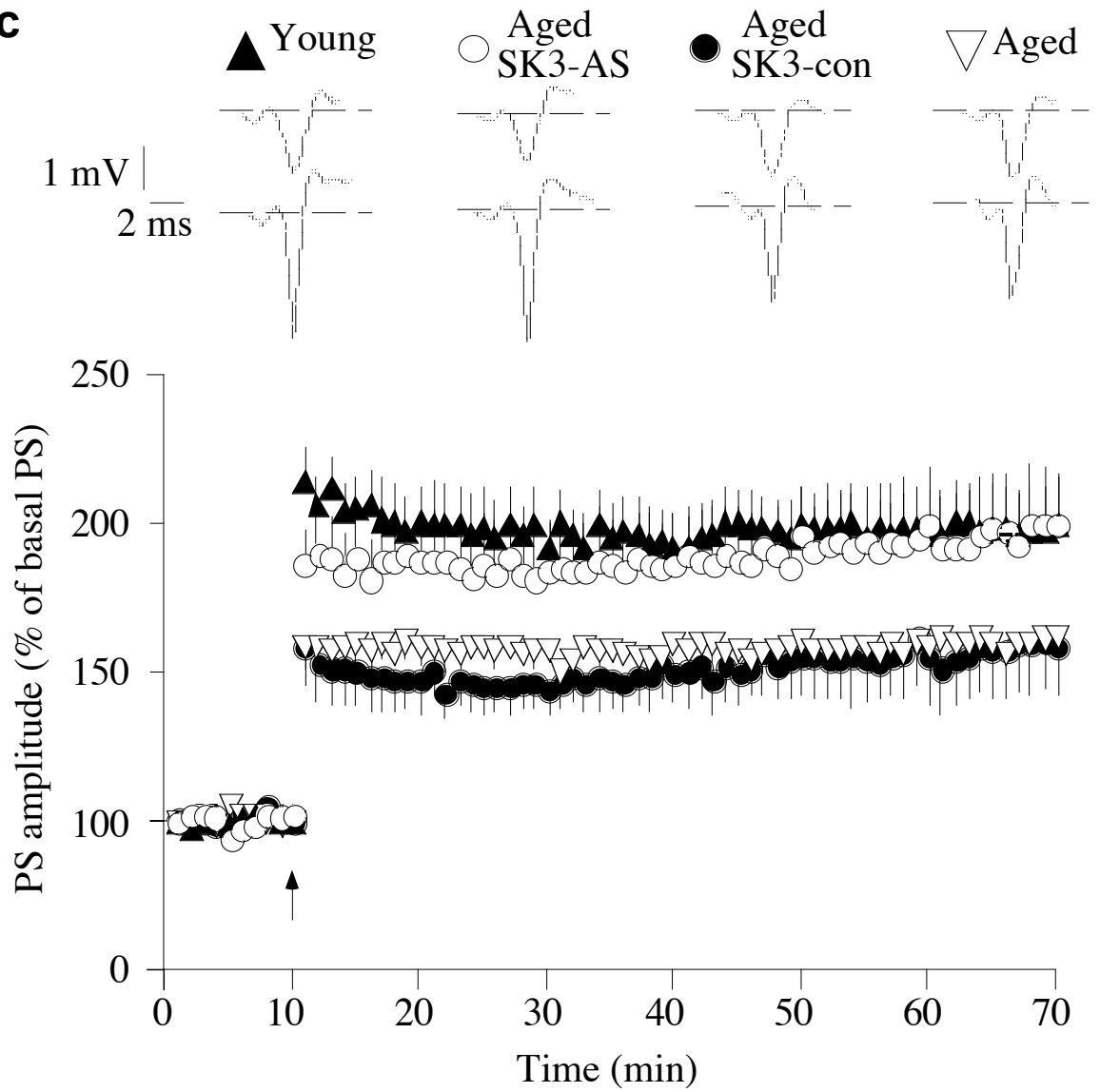


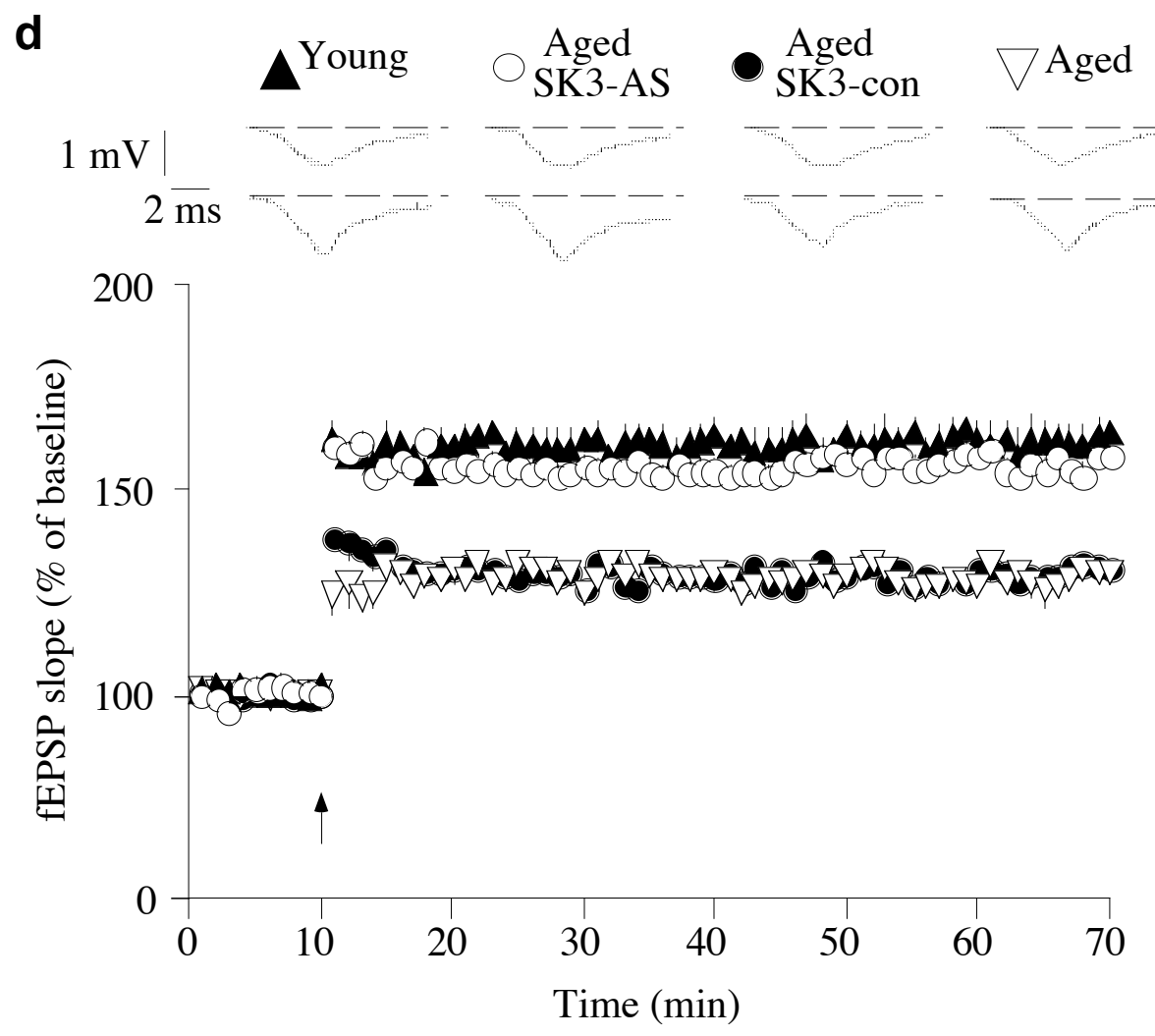

Figure 2 Downregulation of SK3 reversed the age-related impairment of trace fear conditioning, PS-LTP and fEPSP-LTP. (a) Delay fear conditioning. The percentage of freezing in a novel context to tone tested $24 \mathrm{hr}$ after training did not differ significantly ( $P$ $=$ n.s.) in young $(n=6)$ and aged mice $(n=11)$. (b) Trace fear conditioning. Mean percentage of conditioned freezing to the tone for aged mice $(n=17)$ was reduced compared with the freezing of young mice $(* P<0.05, n=6)$. Injection of antisense-SK3 ODNs resulted in a significant enhancement of the freezing response in aged mice $(* P<$ $0.05, n=7)$. No significant change in freezing was seen in aged mice injected with vehicle $(n=6)$ or control ODNs $(n=6)$. Statistics were performed by ANOVA with Fisher's PLSD post hoc test. *Significance $(P<0.05)$ compared with aged mice. (c) Conventional hippocampal slices were used ${ }^{15}$. PS-LTP elicited in slices from young mice was significantly more enhanced ( ; to $199 \pm 10.1 \%$ of baseline; 8 slices, 5 mice; $P<$ 0.01 ) when compared to PS-LTP induced in slices from aged mice ( ; to $161 \pm 3.3 \%$ of baseline; 8 slices, 7 mice). The age-dependent impairment was significantly attenuated when aged mice were pre-injected with antisense ODNs against SK3 ( ; to $198 \pm 12.1 \%$ of baseline; 8 slices, 7 mice; $P<0.01)$. Pre-injection of control ODNs did not significantly affect PS-LTP elicited in hippocampal slices from aged mice ( ; to $158 \pm$ $10.7 \%$ of baseline; 8 slices, 6 mice; $P=$ n.s.). Insets: Responses shown are population spikes recorded during baseline and 55-60 min after the induction of LTP. Traces are averages of six consecutive responses. (d) The magnitude of fEPSP-LTP was significantly larger in slices from young animals ( ; to $164 \pm 3.4 \%$ of baseline; 6 slices, 5 mice; $P<0.001$ ) than in slices from aged animals ( ; to $129 \pm 2.3 \%$ of baseline; 6 slices, 5 mice). Pre-treatment of aged mice with antisense ODNs against SK3 resulted in 
enhanced fEPSP-LTP ( ; to $158 \pm 2.1 \%$ of baseline; 6 slices, 4 mice; $P<0.001$ ), whereas pre-injection of control ODNs had no significant effect on fEPSP-LTP in slices from aged mice ( ; to $130 \pm 1.7 \%$ of baseline; 5 slices, 5 mice; $P=$ n.s.). Insets: Responses shown are fEPSPs recorded during baseline and 55-60 min after the induction of LTP. Traces are averages of six consecutive responses. Data are expressed as means \pm SEM. We tested significance using unpaired Student's $t$-test.

Several studies of aging and LTP have failed to demonstrate any age-related deficits using suprathreshold stimulation paradigms, such as high-frequency stimulation. (Moore, et al., 1993; Lanahan, et al., 1997) In contrast, perithreshold stimulation protocols (such as theta burst and primed burst stimulation) have revealed age-related deficits in the induction of LTP. (Moore, et al.,1993; Lanahan, et al., 1997) Therefore, we induced population spike (PS)-LTP and field excitatory postsynaptic potential (fEPSP)LTP by theta burst stimulation (TBS), at the test pulse intensity, consisting of $5 \times 100 \mathrm{~Hz}$ bursts (five diphasic pulses per burst) with a $200 \mathrm{~ms}$ interburst interval. We stimulated Schaffer collaterals with a bipolar electrode placed on the surface of the slice to record field potentials in the pyramidal cell layer or the dendritic layer of the CA1 area. The stimulus was adjusted to elicit a PS or fEPSP that represented a half-maximal response and was fixed at this level throughout the experiment. (Blank, et al., 2002) The magnitudes of PS-LTP and fEPSP-LTP measured one hour after stimulation were more pronounced in hippocampal slices from young than from aged mice (Figs. 2c and d). PSLTP as well as fEPSP-LTP recorded in slices from aged mice pre-treated with antisense ODNs against SK3 channels did not differ significantly from the potentiation observed in slices from young mice (both $P=$ n.s.). Treatment of aged animals with control ODNs had no significant effect on PS-LTP and fEPSP-LTP (both $P=$ n.s., Figs. 2c and d). These findings point to the SK3 channel as a decisive target involved in the reduced PSLTP and fEPSP-LTP magnitude in area CA1 of the aged mouse hippocampus.

In summary, the data we present here are the first to suggest that increased SK3 channel expression in the hippocampus of aged mice represents a mechanism, which contributes to the age-dependent decline in learning and memory and synaptic plasticity. With the help of SK3 deficient mice we will determine the role of SK3 channels in learning and memory and synaptic plasticity in future experiments. An intervention that 
selectively reduces the function of SK3 channels may be a novel mechanistic approach for pharmacological treatments that might ameliorate or even prevent the memory deficits associated with aging.

\section{Materials and Methods}

\section{Animals}

Experiments were carried out with young (4-6 months) and aged (22-24 months) male C57BL/6J mice maintained under a National Institute of Aging contract with Harlan Sprague-Dawley. Upon arrival the mice were individually housed and maintained on a 12 $\mathrm{hr}$ light/dark cycle (lights on at $7 \mathrm{am}$ ) with free access to food and water. Mice were kept under these housing conditions for at least two weeks before experiments were started. All experimental procedures were in accordance with the European Council Directive (86/609/EEC) and the Animal Section Law under the supervision of the District Government of Braunschweig, Lower Saxony, Germany.

\section{Behavioural experiment}

One trial tone-dependent fear conditioning was performed by a computerized fear conditioning system from TSE (Bad Homburg, Germany) as described previously. (Blank, et al., 2002) Training was performed in a Plexiglas cage (36 x 21 x $20 \mathrm{~cm})$ within a fear conditioning box constantly illuminated (12 V, $10 \mathrm{~W}$ halogen lamp, 100-500 lux). In this conditioning box, a high-frequency loudspeaker (Conrad, KT-25-DT, Hirschau, Germany) provided constant background noise [white noise, $68 \mathrm{~dB}$ sound pressure level (SPL)]. Delay conditioning consisted of exposing the mice for $180 \mathrm{~s}$ to the context followed by a $30 \mathrm{~s}$ tone $(10 \mathrm{kHz}, 75 \mathrm{~dB} \mathrm{SPL}$, pulsed $5 \mathrm{~Hz})$ and $2 \mathrm{~s}$ shock $(0.7 \mathrm{~mA}$, constant current). For trace conditioning mice were placed into the conditioning box for $165 \mathrm{~s}$ and the tone and shock were separated by a $15 \mathrm{~s}$ interval. In both training paradigms, the mouse was removed from the fear conditioning box $30 \mathrm{~s}$ after shock termination to avoid an aversive association with the handling procedure. The tone-

dependent memory test was performed by exposure to a novel context (180 s) followed by the tone employed for conditioning (180 s). Freezing, defined as the lack of movement 
besides respiration and heart beat, was assessed every $10 \mathrm{~s}$. The experimenter was blind to the animal pre-treatment in all studies. The data were converted to the percentage of samples scored as freezing. Locomotor activity was automatically recorded by an infrared beam system (detection rate $10 \mathrm{~Hz}$ ), controlled by the fear conditioning system.

\section{Antisense oligonucleotides}

Antisense oligonucleotides (ODN) and controls directed against mouse SK3 have been provided by Biognostik (Göttingen, Germany). ODNs were shipped as lyophilized DNA-Na salt. The lyophilized ODNs were dissolved in $1 \mathrm{x}$ TE buffer $(10 \mathrm{mM}$ Tris/HCl, $1 \mathrm{mM}$ EDTA; $\mathrm{pH} 7.2)$ to a stock concentration of $2 \mathrm{nmol} / \mu \mathrm{l}$ and stored at $-20{ }^{\circ} \mathrm{C}$. The oligodeoxynucleotide suspension was diluted to a concentration of $0.5 \mathrm{nmol} / \mu 1$ in artificial cerebrospinal fluid (aCSF) with $13 \mu \mathrm{M}$ of the lipophilic transfection reagent DOTAP (Boehringer Mannheim). The mixture was incubated for $15 \mathrm{~min}$ at $37^{\circ} \mathrm{C}$ prior to injection. Animals were injected intracerebroventricularly (i.c.v.) with $1 \mu l$ antisense pro side on day 1, 3 and 5. Animals were decapitated or trained in the fear conditioning paradigm on day 6 . The sequences of the antisense-SK3 and random control oligonucleotides are as follows: antisense-SK3, 5'-CTGTACTTCCCTTGTGTG-3' and random control, 5'-ACTACTACACTAGACTAC-3'.

\section{Cannulation}

Double guide cannulae (C235, Plastics One, Roanoke, Virginia) were implanted using a stereotactic holder during $1.2 \%$ avertin anesthesia $(0.02 \mathrm{ml} / \mathrm{g}$, intraperitoneal $)$ under aseptic conditions as previously described. (Blank, et al., 2002) Each double guide cannula with inserted dummy cannula and dust cap was fixed to the skull of the mouse with dental cement. The cannulae were placed into both lateral brain ventricles, with anteroposterior (AP) coordinates zeroed at Bregma AP $0 \mathrm{~mm}$, lateral $1 \mathrm{~mm}$, depth $3 \mathrm{~mm}$. The animals were allowed to recover for 4-5 d before the experiments started. Bilateral injections were performed using an infusion pump (CMA/100, CMA/Microdialysis, Solna, Sweden) at a constant rate of $0.5 \mu \mathrm{l} / \mathrm{min}$ (final volume: $1 \mu \mathrm{l}$ per side). Cannula placement was verified post hoc in all mice by injection of methylene blue. For 
electrophysiological experiments double guide cannula placement was verified by unilateral methylene blue injection.

\section{Hippocampal slice electrophysiology}

Mice were briefly anesthetized with isoflurane and then decapitated. In less than one minute the skull was opened, the brain removed and transferred to ice-cold aCSF solution of the following composition (in $\mathrm{mM}$ ): $130 \mathrm{NaCl}, 3.5 \mathrm{KCl}, 1.25 \mathrm{NaH}_{2} \mathrm{PO}_{4}, 1.5$ $\mathrm{MgSO}_{4}, 2 \mathrm{CaCl}_{2}, 24 \mathrm{NaHCO}_{3}, 10$ glucose, equilibrated with $95 \% \mathrm{O}_{2} / 5 \% \mathrm{CO}_{2}$ (pH 7.4). Hippocampi were dissected from the chilled brain hemispheres on ice. Transverse hippocampal slices $(400 \mu \mathrm{M})$ were obtained on a McIlwain tissue chopper (The Mickle Laboratory Engineering Co. LTD., Surrey, England) and kept submerged (minimum of 1 $\mathrm{hr}$ at room temperature before recordings) in aCSF. Extracellular field potentials were recorded in a recording chamber maintained at $32{ }^{\circ} \mathrm{C}$ with recording electrodes pulled from borosilicate glass (WPI, Sarasota, FL) and filled with $2 \mathrm{M} \mathrm{NaCl} \mathrm{(3-5} \mathrm{m \Omega ).} \mathrm{All}$ recordings were made using a SEC-05L amplifier (npi Electronics, Tamm, Germany). To record field potentials in the pyramidal cell layer or the dendritic layer of the CA1 area Schaffer collaterals were stimulated with a bipolar electrode placed on the surface of the slice. At the beginning of each experiment, a stimulus-response curve was established by increasing the stimulus intensity and measuring the amplitude of the population spike (PS) or the field excitatory postsynaptic potential (fEPSP) slope. Based on the inputoutput function, the stimulus was adjusted to elicit a population spike or a fEPSP that represented a half-maximal response and was fixed at this level throughout the experiments. PS-LTP and fEPSP-LTP were induced by theta burst stimulation, at the test pulse intensity, consisting of 5 x $100 \mathrm{~Hz}$ bursts (five diphasic pulses per burst) with a 200 ms interburst interval. Traces were stored on a computer using Pulse 7.4 software (HEKA, Lambrecht, Germany) for off-line analysis. PS-LTP and fEPSP-LTP were measured 60 min after tetanic stimulation. The experimenter was blind to the animal pretreatment in all studies. 


\section{References}

Barnes CA, Nadel L and Honig WK Spatial memory deficit in senescent rats Can. J. Psychol. (1980) 34:29-39

Blank T, Nijholt I, Eckart $\mathrm{K}$ and Spiess $\mathrm{J}$ Priming of long-term potentiation in mouse hippocampus by corticotropin-releasing factor and acute stress: implications for hippocampus-dependent learning $\mathrm{J}$. Neurosci. (2002) 22: 3788-3794

Houston FP, Stevenson GD, McNaughton BL and Barnes Effects of age on the generalization and incubation of memory in the F344 rat Learn Mem. (1999) 6:111-119

Lanahan A, Lyford G, Stevenson GS, Worley PF and Barnes CA Selective alteration of long-term potentiation-induced transcriptional response in hippocampus of aged, memory-impaired rats $\mathrm{J}$. Neurosci. (1997) 17: 2876-2885

Landfield PW, McGaugh JL and Lynch G Impaired synaptic potentiation processes in the hippocampus of aged, memory-deficient rats (1978) Brain Res. 150: 85-101

Landfield PW and Pitler TA Prolonged Ca2+-dependent afterhyperpolarizations in hippocampal neurons of aged rats Science (1984) 226: 1089-1092

McEchron MD, Bouwmeester H, Tseng W, Weiss C and Disterhoft JF Hippocampectomy disrupts auditory trace fear conditioning and contextual fear conditioning in the rat Hippocampus (1998) 8 : 638-646

Moore CI, Browning MD and Rose GM Hippocampal plasticity induced by primed burst, but not longterm potentiation, stimulation is impaired in area CA1 of aged Fischer 344 rats Hippocampus (1993) 3: $57-66$

Pedarzani P, Mosbacher J, Rivard A, Cingolani LA, Oliver D, Stocker M, Adelman JP, and Fakler B. Control of electrical activity in central neurons by modulating the gating of small conductance Ca2+activated K+ channels. J Biol Chem. (2001) 276 (13): 9762-9769

Sah P Ca(2+)-activated $\mathrm{K}+$ currents in neurones: types, physiological roles and modulation Trends Neurosci. (1996) 19: 150-154

Schumacher M and Adelman JP Ion channels: an open and shut case Nature (2002) 417: 501-502

Storm JF Potassium currents in hippocampal pyramidal cells Prog. Brain Res. (1990) 83: 161-187

Tacconi S, Carletti R, Bunnemann B, Plumpton C, Merlo Pich E, Terstappen GC Distribution of the messenger RNA for the small conductance calcium-activated potassium channel SK3 in the adult rat brain and correlation with immunoreactivity Neuroscience (2001) 102: 209-215

Wallenstein GV, Eichenbaum $\mathrm{H}$ and Hasselmo ME The hippocampus as an associator of discontiguous events Trends Neurosci. (1998) 21: 317-323

Wu WW, Oh MM and Disterhoft JF Age-related biophysical alterations of hippocampal pyramidal neurons: implications for learning and memory Ageing Res. Rev. (2002) 1: 181-207 


\section{Chapter 5}

\section{Summary and conclusion}

Small conductance $\mathrm{Ca}^{2+}$-activated $\mathrm{K}^{+}(\mathrm{SK})$ channels are believed to be involved in the generation of afterhyperpolarizations (AHPs) found in many central neurons. They are activated by an increase in intracellular calcium levels as seen following single or multiple action potentials (Sah, 1996). Three SK channel subtypes have been cloned from mammalian brain (Kohler et al., 1996). The mRNAs for all three SK channels are present throughout the mammalian central nervous with various densities. In the rat hippocampus, which contributes to several learning and memory processes, SK1 and SK2 channels are dominant with very low levels of SK3 subunits (Kohler et al., 1996; Stocker and Pedarzani, 2000).

The bee venom toxin apamin is known as a selective SK channel blocker. However, all three SK channel subtypes show different sensitivities to apamin. SK2 channels have a high sensitivity to apamin, whereas SK1 channels show very low sensitivity when expressed in Xenopus oocytes (Grunnet et al., 2001). In neurons, apamin can block medium AHPs, therefore SK channels are supposed to be responsible for this type of AHP (Storm, 1989; Savic et al., 2001; Abel et al., 2004, Villalobos et al., 2004).

Here, I showed that the expression level of SK2 channels is regulated by corticosteroids and NF-kappaB. It has already been known that corticosteroids modulate neuronal excitability, but there was no indication on down-stream targets of corticosteroids (Werkman et al., 1997; Pavlides et al., 1995). From the present data modulation of SK2 channel expression represents a potential mechanism to explain the link between changes in neuronal excitability and corticosteroids.

The consequences of corticosteroid-induced changes in SK2 channel expression for brain function are likely to be complex because this channel subtype is assumed to participate in forming a variety of functionally distinct channels. Up-regulation of SK2 
channel genes may play an important role in the control of neuronal excitability and synaptic plasticity because increased levels of SK2 will cause elevated efflux of potassium ions out of the cell and consequently dampen the state of excessive neuronal activity. This in turn will protect the cell from persistent hyperexcitability and ultimately even from neuronal damage (Fig.1). 


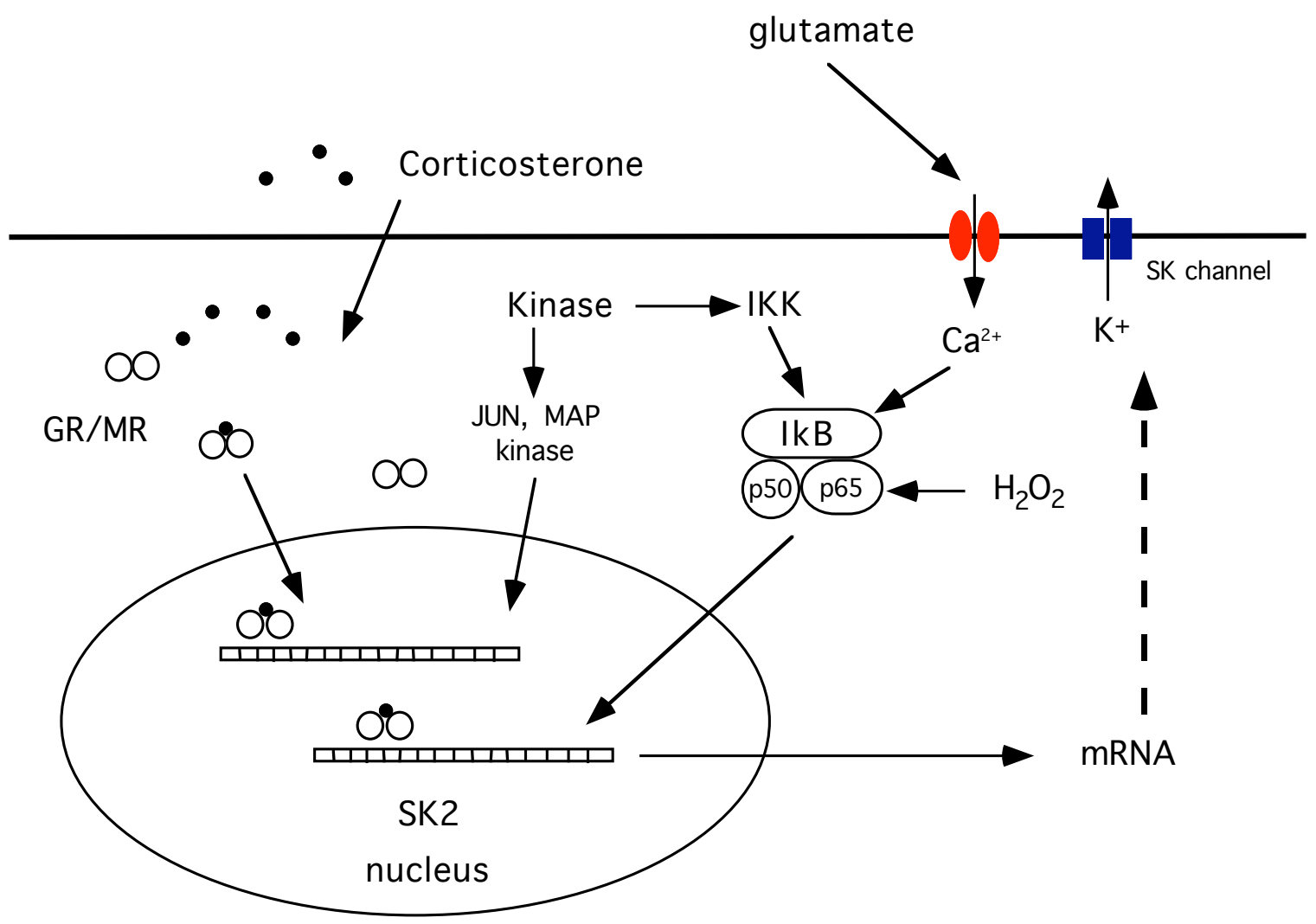

Fig. 1. Schematic diagram of regulation of SK2 gene expression by corticosteroids and NF-kappaB. Corticosteroids can pass the cellular membrane freely and activate its two endogenous receptors, which are in the cytosol. Activated receptors enter the nucleus and modulate as transcription factors SK2 gene expression. The inactivated form of NFkappaB exists in the cytosol as a complex. Kinases activate IKK, and activated IKK in turn phosphorylates IkB. Alternatively, $\mathrm{Ca} 2+$ entering the cell via glutamate receptors can also activate the NF-kappaB complex. Activated NF-kappaB enters the nucleus and acts as a transcription factor on SK2 channel expression.

Another conclusion from this study is the possible role of SK3 channels in agerelated cognitive deficits. As discussed in Chaper 4, aged mice have higher levels of SK3 channel mRNA than young animals. When we decreased the amount of SK3 mRNA by antisense treatment, we observed that impaired LTP and trace fear conditioning fully recovered to the level of young animal. These findings suggest that increased expression levels of SK3 contribute to impaired learning and memory in aged animals. 


\section{References}

Abel HJ, Lee JC, Callaway JC and Foehring RC Relationships between intracellular calcium and afterhyperpolarizations in neocortical pyramidal neurons J Neurophysiol. (2004) 91: 324- 335

Grunnet M, Jensen BS, Olesen SP and Klaerke DA Apamin interacts with all subtypes of cloned smallconductance Ca2+-activated K+ channels Pflugers Arch. (2001) 441: 544- 550

Kohler M, Hirschberg B, Bond CT, Kinzie JM, Marrion NV, Maylie J and Adelman JP Smallconductance, calcium-activated potassium channels from mammalian brain Science (1996) 20: 17091714

Mattson MP, Culmsee C, Yu ZF and Camandola S Roles of nuclear factor $\mathbf{k B}$ in neuronal survival and plasticity J Neurochem. (2000) 74: 443- 456

Pavlides C, Watanabe Y, Magarinos AM and McEwen BS Opposing roles of type I and type II adrenal steroid receptors in hippocampal long-term potentiation Neuroscience (1995) 68: 387- 394

Sah P Ca2+-activated $\mathrm{K}+$ currents in neurons: Types, physiological roles and modulation Trends Neurosci. (1996) 4: 150-154

Savic N, Pedarzani $\mathrm{P}$ and Sciancalepore $\mathrm{M}$ Medium afterhyperpolarization and firing pattern modulation in interneurons of stratum radiatum in the CA3 hippocampal region J Neurophysiol. (2001) 85: 1986- 1997

Stocker $\mathrm{M}$ and Pedarzani P Differential distribution of three Ca2+-activated $\mathrm{K}+$ channel subunits, SK1, SK2, and SK3, in the adult rat central nervous system Mol Cell Neurosci. (2000) 15: 476- 493

Storm JF An after-hyperpolarization of medium duration in rat hippocampal pyramidal cells J Physiol. (1989) 409: 171- 190

Villalobos C, Shakkottai VG, Chandy KG, Michelhaugh SK and Andrade R SK $\mathbf{C K}_{\mathrm{Ca}}$ channels mediate the medium but not the slow Calcium-activated afterhyperpolarization in cortical neurons $\mathrm{J}$ Neurosci. (2004) 24(14): 3537- 3542

Werkman TR, van der Linden S and Joels M Corticosteroid effects on sodium and calcium currents in acutely dissociated rat CA1 hippocampal neurons Neuroscience (1997) 78: 663- 672 


\section{List of Publications}

\section{Full papers}

Blank T, Nijholt I, Kye MJ and Spiess J. Small conductance Ca2+-activated K+ channels as targets of CNS drug development. Curr Drug Targets CNS Neurol Disord. 2004 Jun;3(3): 161-7. Review.

Nijholt I, Farchi N, Kye M, Sklan EH, Shoham S, Verbeure B, Owen D, Hochner B, Spiess J, Soreq H and Blank T. Stress-induced alternative splicing of acetylcholinesterase results in enhanced fear memory and long-term potentiation. Mol Psychiatry. 2004 Feb; 9(2): 174-83.

Blank T, Nijholt I, Kye MJ, Radulovic J and Spiess J. Small-conductance, Ca2+activated $\mathrm{K}+$ channel SK3 generates age-related memory and LTP deficits. Nat Neurosci. 2003 Sep; 6(9): 911-2.

\section{Abstract presentations}

Kye M, Nijholt I, Spiess J and Blank T (2003). Stress and corticosterone regulate SK2 gene expression in mouse hippocampus. Soc. Neurosci. Abstr. 29: 252.17.

Nijholt I, Farchi N, Kye M, Hochner B, Spiess J, Soreq H, and Blank T, (2003). Role of the stress-associated readthrough acetylcholinesterase varient in hippocampal long-term potentiation and fear memory. Soc. Neurosci. Abstr. 29: 623.18 .

Kye M, Nijholt I, Blank T and Spiess J (2002). Acute stress differently affects expression of mRNA coding for SK1, SK2 and SK3 channels in the hippocampus of BALB/C and C57BL/6J mice. Soc. Neurosci. Abstr. 28: 340.7. 


\section{Acknowledgement}

I express thanks to Prof. Dr. Hardeland and Prof. Dr. Schürmann in University of Göttingen for their kind and helpful advice about my thesis.

I am grateful to Prof. Dr. Dr Joachim Spiess. He gave me chance to study very interesting topics.

I am thankful to Dr. Thomas Blank. He was an excellent advisor. I am grateful to Dr. Ingrid Nijholt, Stafanie Vollstädt and Claudia Huschenbett. It was very nice to work with them.

I am appreciative to all colleagues in Department of Molecular Neuroendocrinology, Max Planck Institute for Experimental Medicine.

I especially thank to Dr. Ilga Misane. We shared very good time.

I show appreciation to Dr. Jeong Seop Rhee and his wife Sun Hyae Park. They helped me a lot to live and study in Göttingen. I also thank to their two cheerful sons. They made me laugh.

I am grateful to my friends. They care and motivate me.

I do thank to my father and mother. They always support and believe me. I cannot do anything without their love. I send greeting to my brother, sister-in-law and their newly born son. 


\section{Curriculum Vitae (Lebenslauf)}

Name

Geburtsdatum

Geburtsort

Staatsbürgerschaft

Wohnort

Min-Jeong Kye

25. September 1974

Anyang, Süd Korea

Koreanisch

Zimmerman Strasse 11-Apt. 372

37075 Göttingen

\section{Bildungsweg}

1981 - 1987 Besuch der Myoung Hak Grundschule in Anyang, Süd Korea

1987 - 1990 Besuch der Kwan Yang Girl's Middle School in Anyang, Süd Korea

1990 - 1993 Besuch der Anyang Girl's High School in Anyang, Süd Korea

1993 - 1997 Studium der Biologie an der Sogang-Universität in Seoul, Süd Korea

1997 - 1999 Master of Science, an der Sogang-Universität in Seoul, Süd Korea in der Abteilung Life Science. (Prof. Dr. Jeong-Kug Lee).

Titel:" Analysis of effect of autoinduction system on PHB synthesis metabolism in Rhodobacter Sphaeroides "

2001 - 2004 Dissertation am Max-Planck-Institut für experimentelle Medizin in Göttingen

in der Abteilung Molekulare Neuroendocrinologie

(Prof. Dr. Joachim Spiess).

Titel: "Regulation of small-conductance, calcium-activated potassium channels(SK) in mouse brain in response to aging and stress" 